\title{
Reza_rakhman_-_Skripsi.pdf by
}

Submission date: 23-Mar-2021 12:31AM (UTC-0700)

Submission ID: 1540131983

File name: Reza_rakhman_-_Skripsi.pdf (4.69M)

Word count: 12047

Character count: 79041 
SKRIPSI

RANCANG BANGUN DAN IMPLEMENTASI

PENYIMPANAN FILE SERVER BERBASIS IOT DENGAN

RASPBERRY PI 3B+ MENGGUNAKAN OMV

Diajukan sebagai salah satu syarat

Untuk Memperoleh Gelar Sarjana Jenjang Starta Satu

Pada Program Studi Teknik Informatika

Fakultas Sains dan Teknologi

Universitas Muhammadiyah Sidoarjo

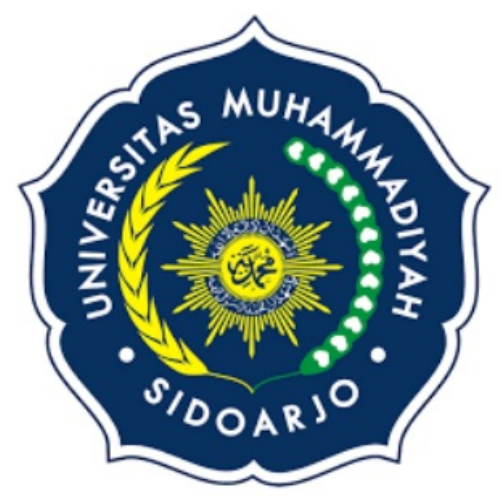

Oleh :

REZA RAKHMAN SANJAYA

NIM : 142080200274

FAKULTAS SAINS DAN TEKNOLOGI

JURUSAN TEKNIK INFORMATIKA (S-1)

UNIVERSITAS MUHAMMADIYAH SIDOARJO

TAHUN AJARAN 2020 - 2021 


\section{RANCANG BANGUN DAN IMPLEMENTASI \\ PENYIMPANAN FILE SERVER BERBASIS IOT DENGAN \\ RASPBERRY PI 3B+ MENGGUNAKAN OMV}

Diajukan sebagai salah satu syarat

Untuk Memperoleh Gelar Sarjana Jenjang Starta Satu

Pada Program Studi Teknik Informatika

Fakultas Sains dan Teknologi

Universitas Muhammadiyah Sidoarjo

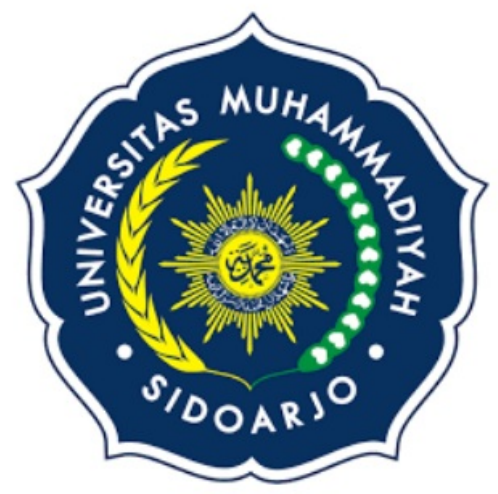

Oleh :

REZA RAKHMAN SANJAYA

NIM : 142080200274

FAKULTAS SAINS DAN TEKNOLOGI

JURUSAN TEKNIK INFORMATIKA (S-1)

UNIVERSITAS MUHAMMADIYAH SIDOARJO

TAHUN AJARAN 2020 - 2021 


\section{HALAMAN PERNYATAAN}

Yang bertanda tangan dibawah ini :

Nama

: Reza Rakhman Sanjaya

Tempat, Tanggal Lahir $\quad$ : Sidoarjo, 9 Juni 1990

NIM

: 14.20802 .00274

Fakultas / Jurusan

: Fakultas Sains dan Teknologi / S-1 Informatika

Menyatakan bahwa tugas akhir yang berjudul "Rancang Bangun dan

Implementasi Penyimpanan File Server Berbasis IoT dengan

Raspberry Pi 3b+ Menggunakan OMV", adalah bukan tugas skripsi, tugas akhir atau karya ilmiah orang lain, kecuali dalam bentuk kutipan yang telah disebutkan sumbernya.

Demikian surat pernyataan ini, saya buat dengan sebenar-benarnya dan apabila pernyataan ini tidak benar maka saya bersedia mendapatkan sanksi akademis.

Sidoarjo, Maret 2021

Yang menyatakan

Reza Rakhman Sanjaya

NIM : 142080200274

Mengetahui

Dosen Pembimbing

Mochamad Alfan Rosid, S.Kom., M.Kom

NIK : 210381 
HALAMAN PERSETUJUAN

RANCANG BANGUN DAN IMPLEMENTASI

PENYIMPANAN FILE SERVER BERBASIS IOT DENGAN

RASPBERRY PI 3B+ MENGGUNAKAN OMV

Skripsi

Jurusan Teknik Informatika (S1)

Yang Diajukan Oleh :

Reza Rakhman Sanjaya

NIM : 142080200274

Telah disetujui Oleh :

Dosen Pembimbing

Mochamad Alfan Rosid, S.Kom., M.Kom

NIK : 210381

Tanggal :

FAKULTAS SAINS DAN TEKNOLOGI

JURUSAN TEKNIK INFORMATIKA (S-1)

UNIVERSITAS MUHAMMADIYAH SIDOARJO

TAHUN AJARAN 2020 - 2021 


\section{LEMBAR PENGESAHAN}

\section{RANCANG BANGUN DAN IMPLEMENTASI PENYIMPANAN FILE SERVER BERBASIS IoT DENGAN RASPBERRY PI 3B+ MENGGUNAKAN OMV}

Tugas Skripsi ini disusun untuk memenuhi salah satu syarat memperoleh gelar Sarjana Komputer (S1)

Di

Universitas Muhammadiyah Sidoarjo

Oleh

Reza Rakhman Sanjaya

Nim : 142080200274

Tanggal Ujian :

Disetujui Oleh :

1. Mochamad Alfan Rosid, S.Kom., M.Kom

NIK : 210381

......................

(Ketua Penguji)

2. Mochamad Suryawinata S.Pd, M.Kom NIK : 216585

(Penguji)

3. Mochamad Suryawinata S.Pd, M.Kom NIK : 210381

(Penguji)

Dekan Fakultas Sains dan Teknologi

Hindarto, S.Kom, M.T. NIP : 197307302005011002 


\section{HALAMAN PERSEMBAHAN}

Pertama-tama marilah kita panjatkan Puji Syukur kehadirat Allah SWT

Tidak Lupa Shalawat beserta salam semoga terlimpahkan pada Nabi Besar Kita

Muhammad SAW, Kepada Keluargannya, para Sahabatnya, Pengikutnya

Ibunda tercinta, Chotijah.

Alm Ayahanda Tercinta, Alm Saikhu.

Saudariku Radina Wulandari.

Bapak Mochamad Alfan Rosid, S.Kom., M.Kom selaku dosen pembimbing.

Bapak Mohammad Suryawinata, S.Pd., M.Kom selaku dosen penguji.

Bapak Mohammad Suryawinata, S.Pd., M.Kom Selaku Dosen Penguji.

Metatia Intan Mauliana, S.Pd, M.Si selaku kepala laboratorium

Bapak Nathan Gusti Ryan selaku dedengkot untuk masalah infrastruktur jaringan.

Bapak Onno W Purbo dan Channel Youtube selaku sesepuhnya yang setiap terkadang. mengikuti live streamingnya maupun rekamanan yang familiar

Kawan-kawan yang beraliran Raspberry Pi dari forum Raspberry Indonesia.

Beberapa channel youtube edukasi dikala menyusun Tugas Skripsi antara lain

Explaining Computers, Triplus Tutorials, Techno Dad Life, dan chanel yang tidak bisa saya sebutkan satu persatu

Dosen dan semua civitas, administrasi di Fakultas Sains dan Teknologi.

Semua mahasiswa Universitas Muhammadiyah Sidoarjo. 


\section{MOTTO}

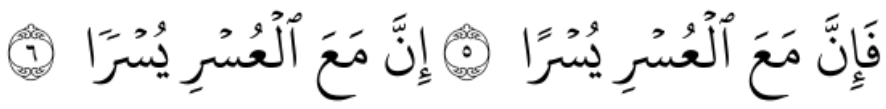

Maka sesungguhnya beserta kesulitan ada kemudahan, sesungguhnya beserta kesulitan itu ada kemudahan.

(Al-Quran Surat Al-Insyirah, Ayat 5-6) 


\title{
Rancang Bangun dan Implementasi Penyimpanan File Server Berbasis IoT dengan Raspberry Pi 3b+ Menggunakan Open Media Vault
}

Nama : Reza Rakhman Sanjaya

NIM : : 142080200274

Pembimbing : Mochamad Alfan Rosid, S.Kom., M.Kom

\begin{abstract}
Abstrak
Pemanfaatan IoT (Internet of Things) secara umum dirasa masih belum terasa dalam dunia bisnis, industri digital, pemerintah terlebih lagi didunia pendidikan. Dimana saat ini pemanfaatan IoT dapat diperuntukan sebagai file server atau media penyimpanan. Sehingga memiliki layanan yang menunjang suatu efektifitas kinerja dalam bekerja, baik disebuah sistem layanan dalam sebuah jaringan ataupun luar jaringan.

Untuk mengoptimalisasikan IoT (Internet of Things) dengan source yang ada, maka perlu mendesain dan mengimplementasi rancang bangun penyimpanan file server berbasis IoT dengan media Raspberry Pi $3 b+$. Dimana rancangan saat ini masih menggunakan satu jaringan dengan penyimpanan file dan hak akses yang sudah ditentukan oleh petugas yang memanejeman kapasitas penyimpanan, pengguna dan hak akses pengguna.

Sistem rancang bangun file server berbasis IoT dengan media Raspberry Pi $3 \mathrm{~b}+$, kedepan mampu sebagai pendatang baru yang bisa di dunia teknologi, dan sebagai alternatif pengganti server dengan biaya yang terjangkau untuk skala pendidikan.
\end{abstract}

Kata Kunci : IoT (Internet of Things), Raspberry Pi, OMV, Linux, Sumber daya (source). 


\title{
Implementation and Design of IoT Based as a File Server Storage With Raspberry Pi 3b + Using Open Media Vault
}

\author{
By : Reza Rakhman Sanjaya \\ Identity Number : 142080200274 \\ Lecturer : : Mochamad Alfan Rosid, S.Kom., M.Kom
}

\begin{abstract}
In general, IoT (Internet of Things) isn't felt in the world of business, digital industry, government, especially in education. At this moment, IoT can be used as a file server as a storage media. It has services that support a performance in worked in a service system in a network or other networks.

To be optimize IoT (Internet of Things) with existing sources. Which is necessary implement and design an IoT-based as a file server storage design of device Raspberry Pi $3 b+$. Where the current design is still uses a network with file storage and access rights that have been determined by officers, which is controling storage capacity, users and user access privilage.

An IoT-based of file server design system with device Raspberry Pi $3 b+$, in the next future is able to become a newcomer to the world of technology, and as an alternative server at an affordable cost for education scale
\end{abstract}

Keywords : IoT (Internet of Things), Raspberry Pi, OMV, Linux, Source. 


\section{KATA PENGANTAR}

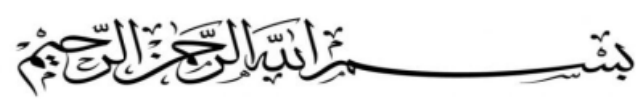

Pertama-tama marilah kita panjatkan Puji Syukur kehadirat Allah SWT, yang telah memberikan kita Nikmat yang sebegitu luar biasa, yakni nikmat iman dan islam dan nikmat sehat walafiat, karena dengan nikmat tersebut, tidak lupa Shalawat beserta salam semoga terlimpahkan pada Nabi Besar Kita Muhammad Saw, Kepada Keluargannya, para Sahabatnya, Pengikutnya, dan kepada kita sekalian.

Adapun maksud penulis bisa menyelesaikan Tugas Akhir dengan judul "Rancang Bangun dan Implementasi Penyimpanan File Server Berbasis IoT Dengan Raspberry PI 3b+ Menggunakan OMV”. Selain itu, juga laporan ini sebagai syarat untuk pelaksanaan mata kuliah Skripsi dalam menyelesaikan program studi Sarjana (S-1) di Universitas Muhammadiyah Sidoarjo. Oleh karenanya, pada kesempatan ini penulis ingin mengucapkan banyak terima kasih kepada :

1. Bapak Drs. Hidayatulloh, M.Si selaku Rektor Universitas Muhammadiyah Sidoarjo.

2. Bapak Hindarto, S.Kom, M.T selaku Dekan Fakultas Teknik

3. Bapak Ir. Sumarno, MM. selaku Kepala Prodi Informatika

4. Bapak Mochamad Alfan Rosid, S.Kom., M.Kom selaku Dosen Pembimbing. Sehingga Penulis dapat menyelesaikan laporan Skripsi ini, dan telah memberikan dorongan, pengetahuan, perbaikan serta saran untuk menyelesaikan laporan ini.

5. Bapak Mohammad Suryawinata, S.Pd., M.Kom selaku Dosen Penguji

6. Bapak Mohammad Suryawinata, S.Pd., M.Kom selaku Dosen Penguji

7. Kedua orang tuaku, ayahku Alm. Saikhu Bin Alm. Maelan Bin Alm Kertojoyo dan ibuku Chotijah terima kasih untuk semua doa, cinta dan kasih sayang, dorongan, semangat, kesabaran, perhatian, nasehat, pengorbanan dan semua yang diberikan kepada penulis. Penulis sangat mencintai kalian berdua yang selama ini menjadi inspirasi, semangat hidup 
dan untuk bisa menjadi anak yang berbakti dan membanggakan kedua orang tua. Rasa sayang dan cinta kalian berdua tidak akan mampu terbalaskan.

8. Adekku, Radina Wulandari yang mendukung baik moral dan doa.

9. Bapak Nathan Gusti Ryan selaku dedengkot untuk masalah infrastruktur jaringan.

10. Bapak Onno W Purbo dan channel Youtube selaku sesepuhnya yang setiap terkadang. mengikuti live streamingnya maupun rekamanan yang familiar dengan keluarga linux.

11. Afiful $e l$ Hasif yang sudah rela meluangkan waktu tempat.

12. Beberapa channel Youtube edukasi dikala menyusun tugas skripsi antara lain Explaining Computers, Triplus Tutorials, Techno Dad Life, dan channel yang tidak bisa saya sebutkan satu persatu.

13. Kawan-kawan yang beraliran Open Source maupun yang Proprietary dari forum Virtual Jogja Community, Indonesia Cloud Computing, Raspberry Pi dari forum Raspberry Indonesia dan forum Echo yang tidak bisa penulis sebutkan satu-persatu.

Penulis mendoakan untuk semua pihak yang telah membantu penulis menyelesaikan laporan akhir ini. Semoga mendapatkan imbalan dan pahala yang setimpal, rezeki yang berlimpah, dirahmati, diberkahi dari Allah SWT.

Semoga dengan terselesaikanya laporan ini dapat memberikan manfaat bagi penulis khususnya dan para pembaca pada umumnya. Oleh karenanya penulis memohon maaf dan selalu terbuka untuk menerima saran dan kritik dari pembaca.

Sidoarjo, Maret 2021

( Reza Rakhman Sanjaya ) 


\section{DAFTAR ISI}

HALAMAN PERNYATAAN ......................................................................... iii

HALAMAN PERSETUJUAN ..................................................................... iv

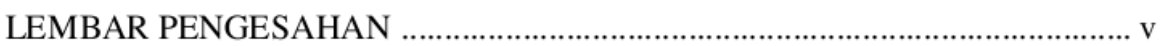

HALAMAN PERSEMBAHAN ................................................................... vi

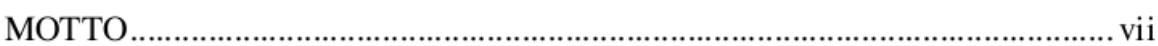

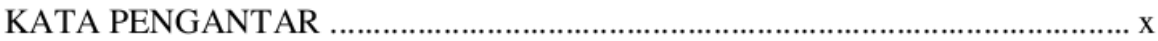

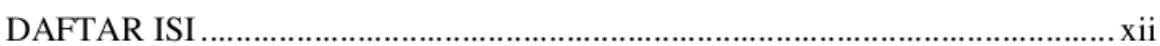

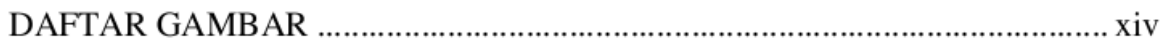

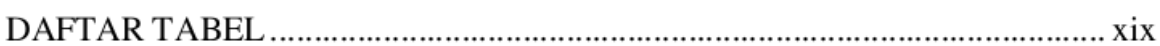

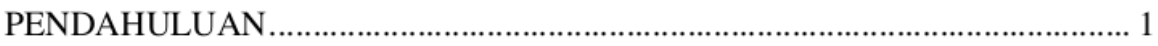

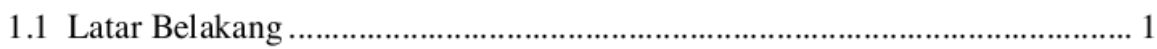

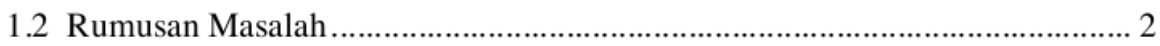

1.3 Batasan Masalah .......................................................................................... 2

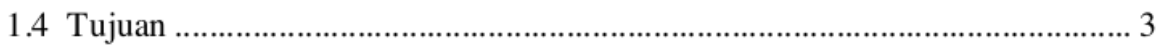

1.5 Manfaat Penelitian .......................................................................................... 3

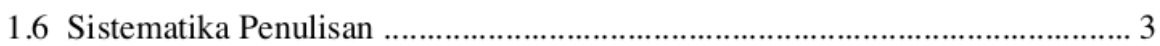

TINJAUAN PUSTAKA DAN DASAR TEORI .................................................... 5

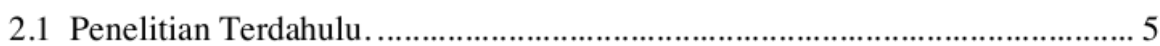

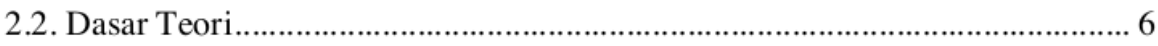

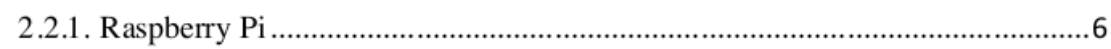

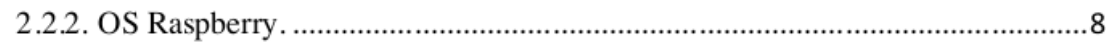

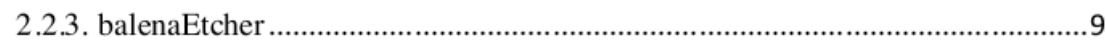

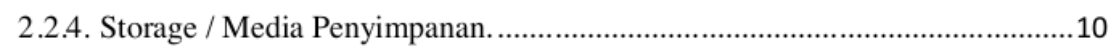

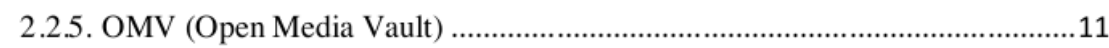

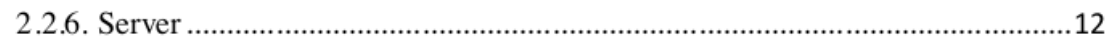

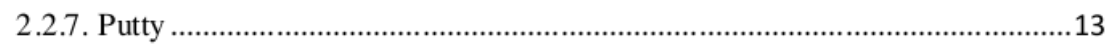

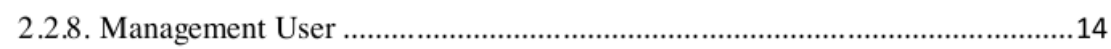

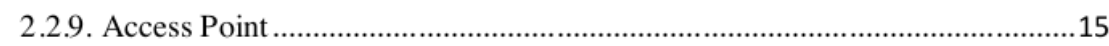

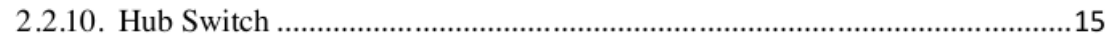

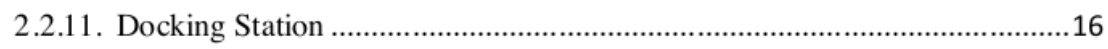

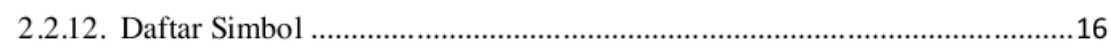

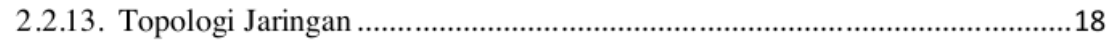




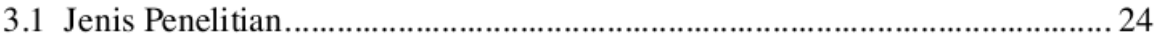

3.2 Pendekatan Penelitian. .................................................................................... 24

3.3 Metode Pengumpulan Data ...................................................................... 24

3.4 Bahan dan Alat Penelitian ............................................................................ 25

3.5 Teknik Pengumpulan Data........................................................................ 27

3.7 Teknik Analisis dari Simulation, Design and Creations ................................. 29

3.7.1 Topologi Hybrid dengan Design and Creations..............................................29

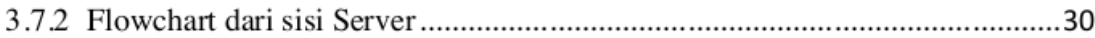

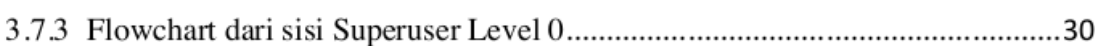

3.7.4 Flowchart dari sisi Pengguna Level 1 ….....................................................31

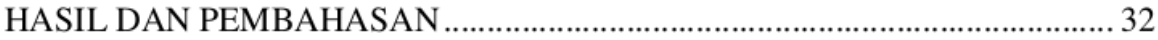

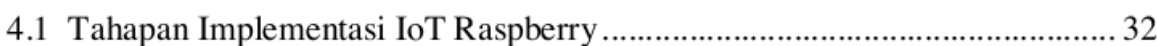

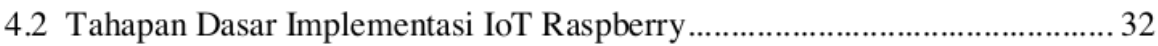

4.2.1 Tahapan Instalasi OMV pada Raspberry Pi 3b+............................................32

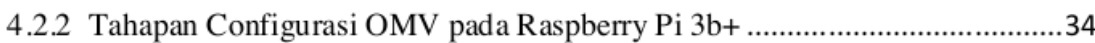

4.2.3 Konfigurasi S.M.A.R.T (Specific, Measurable, Achievable, Relevant dan

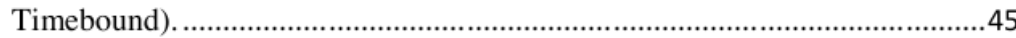

4.2.4 Konfigurasi Media Penyimpanan di OMV (Open Media Vault), serta Konfigurasi Desain and Creation pada Raspberry Pi......................................47

4.2.5 Konfigurasi User Account di OMV (Open Media Vault) ................................52

4.2.6 Konfigurasi Shared Folder di OMV (Open Media Vault). ...............................54

4.2.7 Aktifasi FTP (File Transfer Protokol) di OMV (Open Media Vault) ..............59

4.2.8 Proses Ujicoba FTP pada Jaringan Intranet ................................................61

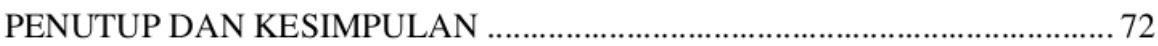

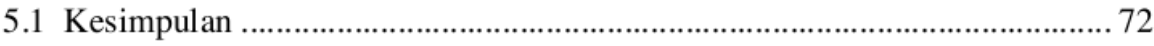

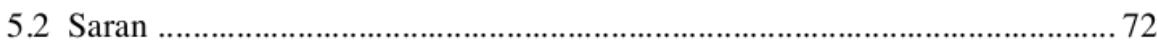

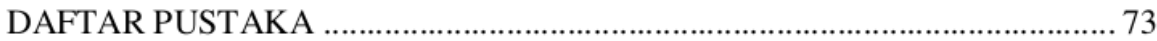




\section{DAFTAR GAMBAR}

Gambar 2.1 Pi Zero ....................................................................................... 7

Gambar 2.2 Raspberry Pi 3 b ................................................................... 7

Gambar 2.3 Raspberry Pi 3 b+ ........................................................... 7

Gambar 2.4 Raspberry Pi 4 b+ ............................................................... 7

Gambar 2.5 Software pendukung balenaEtcher .............................................. 9

Gambar 2.6 Software pendukung Noobs ......................................................... 9

Gambar 2.7 Operating Sistem yang dapat diinstall ......................................... 9

Gambar 2.8 SSD Jenis M.2 …...................................................................... 10

Gambar 2.9 SSD Jenis NVMe M.2 ….......................................................... 10

Gambar 2.10 Jenis MMS dan Adapter ......................................................... 10

Gambar 2.11 Logo Open Media Vault .......................................................... 11

Gambar 2.12 Tampilan Putty ...................................................................... 13

Gambar 2.13 Manajement grup pada Open Media Vault ................................ 14

Gambar 2.14 Penambahan folder user ............................................................. 14

Gambar 2.15 Perangkat keras access point ................................................... 14

Gambar 2.16 Perangkat keras hub swicth ...................................................... 15

Gambar 2.17 Perangkat keras docking station ................................................ 15

Gambar 2.18 Topologi Bintang......................................................................... 19

Gambar 2.19 Topologi Cincin (Ring) ........................................................... 19

Gambar 2.20 Topologi Bus ....................................................................... 20

Gambar 2.21 Topologi Tree / Topologi Pohon .............................................. 20

Gambar 2.22 Topologi Hybrid .................................................................... 21

Gambar 2.23 Topologi Mesh ....................................................................... 22

Gambar 3.1 Metode Kerangka Penelitian Model Waterfall ............................. 27

Gambar 3.2 Kerangka Penelitian Raspberry Pi 3b+ ...................................... 28

Gambar 3.3 Kerangka Metodologi Simulation, Design and Creations ............ 28

Gambar 3.4 Flowchart dari sisi Raspberry ........................................................ 29

Gambar 3.5 Flowchart dari sisi Superuser Level 0 ......................................... 29

Gambar 3.6 Flowchart dari sisi Superuser Level 1 ......................................... 30

Gambar 4.1 Format Micro SD ke mode quick format ................................... 31

Gambar 4.2 Tampilan aplikasi balenaEtcher ................................................ 32 
Gambar 4.3 Buka aplikasi OMV menggunakan balenaEtcher 32

Gambar 4.4 Pilih lokasi Micro SD setelah itu lanjut ...................................... 32

Gambar 4.5 Pilih flash untuk melakukan pada Micro SD ............................... 33

Gambar 4.6 Proses flasing sedang berlangsung ............................................ 33

Gambar 4.7 Proses flasing sudah selesai ............................................................ 33

Gambar 4.8 Tampak bawah Micro SD Raspberry Pi 3b+ ............................. 33

Gambar 4.9 Tampilan mode teks pada Open Media Vault ............................... 34

Gambar 4.10 Tampak tampilan versi Open Media Vault dan nomor alamat IP yang digunakan pada mode versi teks ....................... 34

Gambar 4.11 Login dengan webbrowser untuk langkah awal konfigurasi Open Media Vault .................................................. 35

Gambar 4.12 Tampak halaman awal Open Media Vault ................................. 35

Gambar 4.13 Tampak lebih rinci halaman informasi mengenai kondisi sistem Open Media Vault ............................................... 35

Gambar 4.14 Konfigurasi hostname dan domainname .................................... 36

Gambar 4.15 Tampilan notifikasi untuk pembaruan konfigurasi .................... 36

Gambar 4.16 Tampilan nilai awal pada perintah session timeout ................. 37

Gambar 4.17 Tampilan nilai awal sesudah diubah pada perintah session timeout ...................................................................... 37

Gambar 4.18 Tampilan ubah password ......................................................... 37

Gambar 4.19 Tampilan permit root masih pada posisi Off .............................. 38

Gambar 4.20 Tampilan permit root sudah diposisi On .................................. 38

Gambar 4.21 Tampilan putty yang sudah disesuaikan dengan alamat IP ....... 38

Gambar 4.22 Tampilan pemberitahuan siap digunakan .................................. 39

Gambar 4.23 Tampilan masuk sebagai superuser ............................................ 39

Gambar 4.24 Tampilan untuk perubahan password pada posisi superuser ..... 39

Gambar 4.25 Perintah untuk memperbaharui dan mengupgrade kernel pada sistem Open Media Vault ..................................... 40

Gambar 4.26 Perintah menghapus file ......................................................... 40

Gambar 4.27 Perintah general berupa text ................................................... 40

Gambar 4.28 Perintah general untuk mempermudah ...................................... 40 
Gambar 4.29 Perintah melakukan reboot menggunakan terminal 41

Gambar 4.30 Letak posisi reboot menggunakan interface ........................... 41

Gambar 4.31 Perintah download dari source code Github ........................... 41

Gambar 4.32 Perintah copy sources.list menjadi sources.list_backup ............ 41

Gambar 4.33 Script awal sources.list pada direktori /etc/apt/ .......................... 42

Gambar 4.34 Script tambahan setelah perintah diatas ................................. 42

Gambar 4.35 Perintah membuat direktori .................................................... 43

Gambar 4.36 Perintah masuk kedalam direktori ........................................... 43

Gambar 4.37 Perintah membuat isi script file satu.sh ................................. 43

Gambar 4.38 Perintah isi script pada file satu.sh ............................................ 43

Gambar 4.39 Perintah membuat isi script file dua sh .................................. 44

Gambar 4.40 Perintah isi script pada file dua.sh ....................................... 44

Gambar 4.41 Perintah eksekusi dalam satu kali perintah ............................. 44

Gambar 4.42 Perintah melakukan eksekusi dua file secara bersamaan ............ 44

Gambar 4.43 Proses pembaharuan versi 3.0.100 telah selesai......................... 45

Gambar 4.44 Login dengan webbrowser ................................................... 45

Gambar 4.45 Proses aktifasi SMART ...................................................... 46

Gambar 4.46 Pilih salah satu drive dan klik edit. .......................................... 46

Gambar 4.47 Aktifasi monitoring SMART . .................................................. 46

Gambar 4.48 Proses aktifasi SMART pada semua media .............................. 46

Gambar 4.49 Device belum terpasang pada perangkat Raspberry Pi 3b+ ....... 47

Gambar 4.50 Device yang terpasang sudah muncul pada perangkat

Raspberry Pi 3b+ ............................................................ 47

Gambar 4.51 Proses penghapusan data pada semua device yang terpasang .... 48

Gambar 4.52 Notifikasi konfirmasi device akan dihapus .............................. 48

Gambar 4.53 Pilih metode untuk menghapus device ................................... 48

Gambar 4.54 Proses wiping divice sedang berlangsung .............................. 48

Gambar 4.55 Proses pembuatan RAID ....................................................... 49

Gambar 4.56 Proses pemilihan Harddisk ...................................................... 49

Gambar 4.57 Pemilihan jenis Raid yaitu RAID 5 ......................................... 49

Gambar 4.58 Pilih semua drive untuk pengunaan RAID 5 ........................... 50

Gambar 4.60 Proses RAID 5 selesai dan klik Apply ........................................ 50 
Gambar 4.61 Proses mounting device

Gambar 4.62 Proses create file system dengan memilih device dan jenis file system yang digunakan ........................................ 51

Gambar 4.63 Notifikasi konfirmasi device akan dihapus ................................ 51

Gambar 4.64 Proses create file system sedang berlangsung ............................ 51

Gambar 4.65 Proses mounting Harddisk RAID ........................................... 52

Gambar 4.66 Tampilan notifikasi untuk pembaruan konfigurasi ................... 52

Gambar 4.67 Tampilan konfigurasi pembuatan user account untuk Open Media Vault ............................................................. 52

Gambar 4.68 Tampilan form akun ................................................................. 53

Gambar 4.69 Tampilan akun sesuai dengan kebutuhan .................................... 53

Gambar 4.71 Tahapan konfigurasi shared folder ............................................ 54

Gambar 4.72 Tampilan konfigurasi shared folder ........................................... 54

Gambar 4.73 Tampilan device yang muncul hanya muncul satu karena sudah diubah menjadi RAID 5 .................................................. 54

Gambar 4.74 Tampilan konfigurasi shared folder .......................................... 55

Gambar 4.75 Tampilan akhir konfigurasi shared folder .................................. 55

Gambar 4.76 Pilih drive kemudian klik privilage ........................................... 55

Gambar 4.77 Ubah posisi semua user menjadi status Read/Write.................... 55

Gambar 4.78 Tampilan aplikasi WinSCP ………......................................... 56

Gambar 4.79 Tampilan konfigurasi WinSCP untuk login ............................... 56

Gambar 4.80 Tampilan folder teratas berupa folder RAID. ........................... 56

Gambar 4.81 Tampilan pembuatan folder Grup 1 hingga Grup 3 ................... 57

Gambar 4.82 Tampilan sesudah membuat folder Grup 1 hingga Grup 3 ........ 57

Gambar 4.83 Pilih drive kemudian pilih ACL ............................................... 57

Gambar 4.84 Untuk folder paling atas berupa Raid, konfigurasi

dengan mode Read/Write............................................................ 58

Gambar 4.85 Untuk folder Grup 1 dikonfigurasikan sesuai kebutuhan ........... 58

Gambar 4.86 Untuk folder Grup 2 dikonfigurasikan sesuai kebutuhan............ 58

Gambar 4.87 Untuk folder Grup 3 dikonfigurasikan sesuai kebutuhan............ 59

Gambar 4.89 Konfigurasi FTP pada OMV …………................................... 60

Gambar 4.90 Bagian yang akan dishare …........................................................... 60 
Gambar 4.91 Pilih drive yang tersedia. 60

Gambar 4.92 Pembuatan user, login dan port pada WinSCP ....................... 61

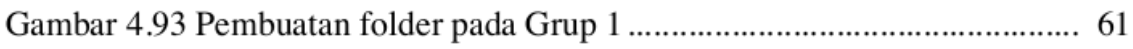

Gambar 4.94 Pembuatan gagal karena user Resa hanya bisa membaca ......... 62

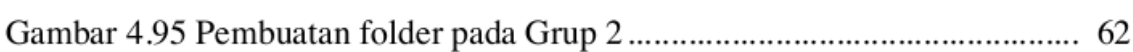

Gambar 4.96 Pembuatan folder pada Grup 2 berhasil .................................... 62

Gambar 4.97 Untuk di folder Grup 3, tidak berhasil diakses ......................... 63

Gambar 4.98 Cara terhubung melalui FTP tanpa pihak ketiga ....................... 63

Gambar 4.99 Login menggunakan user Aca ............................................... 64

Gambar 4.100 Pembuatan folder pada Grup 1 ................................................ 64

Gambar 4.101 Pembuatan folder pada Grup 1 berhasil ................................. 64

Gambar 4.102 Untuk di folder Grup 2, tidak berhasil diakses....................... 64

Gambar 4.103 Membuat folder pada folder Grup 3 ................................... 65

Gambar 4.104 Untuk di folder Grup 3, perintah tidak berhasil ...................... 65

Gambar 4.105 Mencoba menghapus folder dari folder Grup 3 ....................... 65

Gambar 4.106 Menghapus gagal dalam folder Grup 3 ............................... 65

Gambar 4.107 Tampilan aplikasi FEFileExplorer ........................................6 66

Gambar 4.108 Tampilan menu penambahan koneksi ................................... 66

Gambar 4.109 Pilih tambahan berupa tambah koneksi ............................... 67

Gambar 4.110 Konfigurasi koneksi yang terhubung pada Open Media Vault . 67

Gambar 4.111 Tampilan berhasil membuat koneksi dari tahapan sebelumnya 68

Gambar 4.112 Tampilan berhasil login dari user login Ali .......................... 68

Gambar 4.113 Folder Grup 1 tidak berhasil diakses ....................................... 69

Gambar 4.114 Tahapan membuat folder pada Grup 2 ................................. 69

Gambar 4.115 Membuat nama pada folder Grup 2 .................................... 69

Gambar 4.116 Pada Grup 2 gagal membuat folder .................................... 70

Gambar 4.117 Membuat nama pada folder Grup 3 ........................................ 70

Gambar 4.118 Membuat folder berhasil pada folder Grup 3 ......................... 70

Gambar 4.119 Tampilan akhir rancang bangun dan implementasi penyimpanan file server berbasis IoT dengan Raspberry Pi 3b+ ................ 71 


\section{DAFTAR TABEL}

Tabel 2.1 Penelitian terdahulu. 5

Tabel 2.2 Daftar simbol flowmap 16

Tabel 2.3 Daftar simbol block diagram 17

Tabel 2.4 Daftar simbol flowchart 17

Tabel 4.59 Pilih aneka jenis drive dengan tujuan tercipta desain and creation. 50

Tabel 4.70 Tabel user dan akun sesuai dengan kebutuhan 53

Tabel 4.88 Tabel akses user/grup akses 59 


\section{BAB I}

\section{PENDAHULUAN}

\subsection{Latar Belakang}

Pemanfaatan IoT (Internet of Things) secara umum dirasa masih belum terasa dalam dunia bisnis, industri digital, pemerintah terlebih lagi didunia pendidikan. Dimana saat ini pemanfaatan IoT dapat diperuntukan sebagai file server atau media penyimpanan. Sehingga memiliki layanan yang menunjang suatu efektifitas kinerja dalam bekerja, baik disebuah sistem layanan.

Untuk mengoptimalisasikan IoT (Internet of Things) dengan source yang ada. Maka perlu mendesain dan mengimplementasi rancang bangun penyimpanan file server berbasis IoT. Dimana rancangan saat ini masih menggunakan satu jaringan dengan penyimpanan file dan hak akses yang sudah ditentukan oleh petugas yang memanejeman kapasitas penyimpanan, pengguna dan hak akses pengguna.

Saat ini banyak sekali varian manufaktur yang mendesain komputer sesuai dengan permintaan pasar untuk kepentingan membangun sebuah server. Akan tetapi, kendala keuangan menjadi faktor dalam membangun sebuah layanan penyimpanan, terlebih lagi bilamana hal tersebut diprioritaskan untuk membangun file server dalam dunia pendidikan Oleh sebab itu, muncul sebuah mini komputer yang bernama "Raspberry Pi" atau sering juga disingkat Raspi yang merupakan cikal bakal sebuah generasi yang bernama IoT (Internet of Think).

Dalam menyelesaikan kasus tersebut diatas, penulis berusaha untuk meminimalisir sumber, seperti listrik dan keuangan serta mengoptimalkan prosesor, ruang hardisk, memory serta jaringan yang telah ada. Selain itu, dengan berbagai layanan pada sebuah sumber daya pada sebuah server tidak menjadi sesuatu yang terbuang sia-sia.

Diharapkan dengan rancang bangun dan implementasi penyimpanan File berbasis IoT dengan Server Raspberry Pi 3 b+ menggunakan OMV (Open Media Vault), kedepan sebagai pengelola mampu mengoptimalkan sumber daya yang ada. Serta pengelolaan dari segi perawatannya, penyelamatan data (recovery) lebih mudah, serta kebutuhan-kebutuhan 
lainnya guna menunjang layanan yang lebih baik dari sebelumnya serta meminimalisir sumber daya yang terbuang percuma.

Sistem rancang bangun file server berbasis IoT dengan media Raspberry Pi $3 \mathrm{~b}+$, kedepan mampu sebagai pendatang baru yang bisa di dunia teknologi, dan sebagai alternatif pengganti server dengan biaya yang terjangkau untuk skala pendidikan.

\subsection{Rumusan Masalah}

Penulis perlu memandang permasalah penilitian yang diangkat perlu dibatasi variabelnya agar penelitian ini dapat dilakukan lebih fokus, sempurna dan mendalami layanan atau service yang digunakan adalah layanan file sharing dengan batasan hanya apakah mampu Raspberry Pi menjalankan layanan tersebut, dimana SD Card dipergunakan sebagai media operating sistem dan SSD M.2 (Solid State Drive) sebagai media penyimpanan

\subsection{Batasan Masalah}

1. Rancangan ini menggunakan sebuah Raspberry $P i$ versi $3 b+$.

2. Pada rancang bangun ini menggunakan satu personal computer sebagai administrator (pengelola), satu computer dan sebuah smartphone yang digunakan sebagai client yang nantinya digunakan sebagai transfer file.

3. Layanan penyimpanan strorage ini berjalan hanya pada platform segala turunan dari produk Windows dan iOS yang berada dalam network jaringan intranet.

4. Rancang bangun dan implementasi penyimpanan file server ini mengunakan Linux dengan basis Debian dengan turunan Raspberry 


\subsection{Tujuan}

Tujuan penelitian adalah apakah mampu dengan minimnya sumber daya mampu membangun sebuah file server dengan sumber daya agar yang bisa dipergunakan secara bersama-sama dan tidak terbuang sia-sia dengan pengunaan Raspberry Pi 3b+ dengan menggunakan SSD M.2 (Solid State Drive) sebagai media penyimpanan yang nantinya bisa diterapkan dilingkungan civitas pendidikan maupun organisasi lain.

\subsection{Manfaat Penelitian}

Hasil penelitian ini bertujuan untuk mengoptimalisasikan sumber daya mulai dari pengunaan memory, prosesor, hardisk serta jaringan yang telah tersedia. Selain itu, memanfaatkan yang terdapat pada kinerja sebuah sistem layanan yang selama ini selalu beranggapan sebuah sistem berjalan pada satu jenis operating sistem. Selain itu, guna menghasilkan sebuah produk layanan yang saling bersinergi antara satu layanan dengan layanan yang lain

\subsection{Sistematika Penulisan}

Sistematika studi ini dibagi menjadi beberapa bab bahasan yang meliputi :

\section{BAB I : PENDAHULUAN}

Bab ini berisi tentang latar belakang, rumusan masalah, tujuan, manfaat, batasan masalah, dan sistematika penulisan yang digunakan.

\section{BAB II : TINJAUAN PUSTAKA}

Bab ini membahas tentang tinjauan umum dan landasan teori yang berhubungan dengan pembuatan skripsi ini.

\section{BAB III : METODOLOGI PENELITIAN}

Bab ini membahas tentang metodologi penelitian yang meliputi lokasi, waktu penelitian, bahan, alat penelitian, teknik pengumpulan data dan teknik analisa data. 


\section{BAB IV : HASIL DAN PEMBAHASAN}

Bab ini menjelaskan tetang implementasi dari sistem yang dibuat yaitu tetang kegiatan implementasi itu sendiri. Dengan tujuan untuk mempermudah dalam menyelesaikan tugas - tugas yang berhubungan dengan Rancang Bangun dan Implementasi Penyimpanan File Server Berbasis IoT Dengan Raspberry Pi 3b+ Menggunakan OMV.

\section{BAB V : PENUTUP}

Bab ini berisi tentang kesimpulan dari pembuatan sistem ini dan saran - saran dan harapan kedepan dalam tahapan pengembangan selanjutnya 


\section{BAB II}

\section{TINJAUAN PUSTAKA DAN DASAR TEORI}

\subsection{Penelitian Terdahulu.}

Sebelum melakukan rancang bangun dan implementasi penyimpanan file server berbasis IoT dengan Raspberry $\mathrm{Pi} 3 \mathrm{~b}+$ menggunakan OMV, peneliti sudah melakukan pengumpulan beberapa jurnal perkuliahan, majalah elektronik bertemakan Raspberry $\mathrm{Pi}$ yang dikeluarkan dalam situs www.magpi.cc/store yang sekiranya bisa menjadikan pegangan dalam melakukan rancang bangun dan implementasi, antara lain ;

\begin{tabular}{|c|c|c|c|c|}
\hline No & $\begin{array}{l}\text { Nama, } \\
\text { Sumber }\end{array}$ & Judul, Tahun & Metode & Hasil \\
\hline 1. & $\begin{array}{l}\text { Subandri } \\
\text { Sabar } \\
\text { Hanadwipu } \\
\text { tra, } \\
\text { STMIK } \\
\text { Bani Saleh }\end{array}$ & 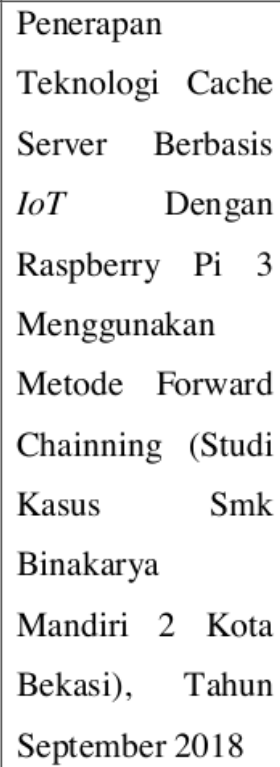 & $\begin{array}{l}\text { Menggunakan } \\
\text { metode } \\
\text { Forward } \\
\text { Chainning. }\end{array}$ & $\begin{array}{lr}\text { Proxy } & \text { server } \\
\text { pada } & \text { Raspberry } \\
\text { Pi } 3 & \text { dapat } \\
\text { berjalan dan } & \text { mampu } \\
\text { menghemat } \\
\text { penggunaan } \\
\text { bandwidth } \\
\text { internet. }\end{array}$ \\
\hline 2. & $\begin{array}{l}\text { Agung } \\
\text { Purwo } \\
\text { Wicaksono. }\end{array}$ & $\begin{array}{l}\text { Rancang Bangun } \\
\text { Penyimpanan } \\
\text { pada Jaringan } \\
\text { Menggunakan } \\
\text { FreeNAS } \\
\text { (Development of } \\
\text { Network Storage }\end{array}$ & $\begin{array}{l}\text { Menggunakan } \\
\text { metode } \\
\text { teknologi } \\
\text { virtualisasi } \\
\text { dengan } \\
\text { aplikasi } \\
\text { Virtual box }\end{array}$ & $\begin{array}{l}\text { Memungkinkan } \\
\text { mengakses dan } \\
\text { mengelola } \\
\text { FreeNas dapat } \\
\text { diakses melalui } \\
\text { interface } \\
\text { webbrowser, }\end{array}$ \\
\hline
\end{tabular}




\begin{tabular}{|c|c|c|c|c|}
\hline & $\begin{array}{l}\text { Muham } \\
\text { madiyah } \\
\text { Purwokerto }\end{array}$ & $\begin{array}{l}\text { Using Free NAS), } \\
\text { Mei } 2016\end{array}$ & $\begin{array}{l}\text { dengan OS } \\
\text { based berbasis } \\
\text { Windows } 7\end{array}$ & $\begin{array}{l}\text { serta user dapat } \\
\text { mengakses } \\
\text { dalam mode } \\
\text { windows } \\
\text { explorer dalam } \\
\text { mode network } \\
\text { dan untuk user } \\
\text { pengguna linux } \\
\text { dapat ditemui } \\
\text { dalam mode } \\
\text { SMB (Server } \\
\text { Message Block). }\end{array}$ \\
\hline 3. & $\begin{array}{l}\text { Anwar } \\
\text { Sandi } \\
\text { UIN } \\
\text { Alauddin } \\
\text { Makassar }\end{array}$ & $\begin{array}{l}\text { Pemanfaatan } \\
\text { Rasberry Pi } \\
\text { Sebagai Server } \\
\text { Portable, } \\
\text { November } 2017\end{array}$ & $\begin{array}{l}\text { Metode } \\
\text { Perancangan } \\
\text { Sistem } \\
\text { Prototype }\end{array}$ & $\begin{array}{l}\text { Raspberry Pi } \\
\text { yang merupakan } \\
\text { server portable } \\
\text { dapat } \\
\text { menggantikan } \\
\text { fungsi } \\
\text { server yang } \\
\text { berbiaya mahal }\end{array}$ \\
\hline
\end{tabular}

\subsection{Dasar Teori}

\subsubsection{Raspberry $\mathbf{P i}$}

Raspi atau sering disebut Raspberry, merupakan suatu mini komputer yang memiliki papan tunggal (Single Board Circuit/SBC) yang memiliki ukuran selebar kartu KTP. Raspi memiliki beberapa jenis varian dan kini sudah ketahap varian yang ke 4, yaitu Raspberry Pi Model 4. Raspberry Pi memiliki dua model berupa model A dan model B. Secara umum perbedaan model A dan B terletak pada pengunaan memory dan System on Chip (SoC) dimana pada model A yaitu Raspberry Pi 1 A+ memiliki memory 512 MB dengan jenis broadcom Broadcom BCM2835, ARMv6 32bit SoC @700 MHz dan 
model B yaitu Raspberry Pi 2 B varian keatas sudah memiliki memory 1 GB dengan jenis Broadcom BCM2837B0, ARM Cortex A53 64 bit SoC@ 900GHz, kecuali Raspberry Pi 1 b+ masih memiliki memory 512 MB masih menggunakan Broadcom BCM2835 (ARMv6) 32-bit SoC@700GHz.

Untuk penyimpanan data, pada Raspberry Pi baik dari generasi pertama hingga terakhir tidak didesain menggunakan Harddisk ataupun Solid State Drive, melainkan mengandalkan kartu SD (SD Memory Card $)$ dengan tipe class $10(10 \mathrm{mb} / \mathrm{s})$ untuk proses booting dan penyimpanan jangka panjang. Untuk real time clock, pada Raspberry Pi tidak memilikinya. Sehingga Operating Sistem pun harus memanfaatkan NTP (Network Time Protokol) sebagai pengantinya. Sesuai perkembangan divarian terbaru dan $\frac{2}{2}$ udah dikembangkan ini sudah terdapat fungsi real-time, dan bisa melalui saluran GPIO (General-Purpose Input/Output) via antarmuka $I^{2} C$ (Inter-Integrated Circuit).

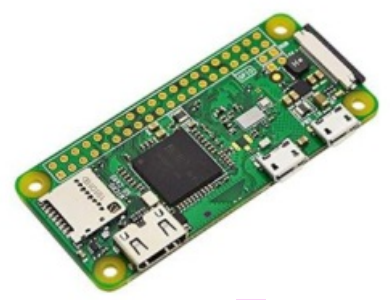

Gambar 2.1 Pi Zero

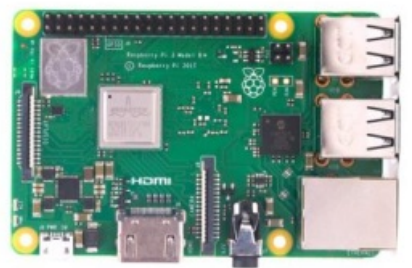

Gambar 2.3

Raspberry Pi 3 b+

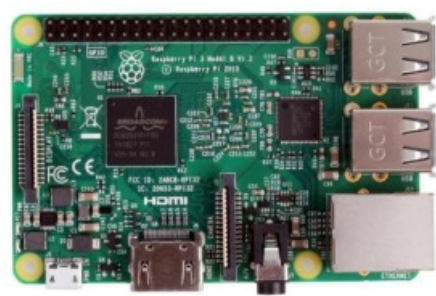

Gambar 2.2

Raspberry Pi 3 b

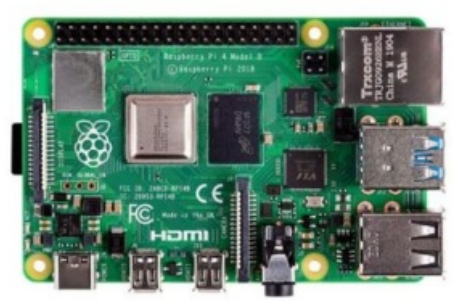

Gambar 2.4

Raspberry Pi 4 b+ 
Untuk kelengkapan sebuah unit Raspberry Pi 3 b+ secara umum terdiri dari modul Raspi 3b+, Micro SDHC dengan kategori class 10 (jika ingin mencoba install sendiri bisa mendownload balenaEtcher dan NOOBS), adapter $5 \mathrm{~V} 2.5 \mathrm{~A}$. Untuk kelengkapan hardcase bisa mendesain sendiri sesuai keinginanxcv diri sendiri dan kebutuhan. Sedangkan untuk Output menggunakan HDMI bila tidak memungkinan bisa menggunakan converter HDMI to VGA,.

\subsubsection{OS Raspberry.}

Raspberry OS atau sering disebut Raspi OS, merupakan sistem operasi berbasis turunan dari Debian yang dipergunakan khusus untuk keluarga Raspi dari Raspi Zero hingga Raspi 4B+ dengan manufaktur papan tunggal (Single Board Circuit/SBC). OS PI ini dari menawarkan versi 64-bit dengan generasi Raspi 2 Model B versi keatas dengan CPU jenis ARM, dengan kemampuan LXDE sebagai pengelola jendela susun. Sedangkan untuk tema menggunakan Openbox yang dilengkapi browser ringan dengan disupport oleh Google berupa Chromium dengan versi terbaru.

Dimana sebelum mengunakan OS Raspberry secara pengguna terlebih dahulu mendownload balenaEtcher dan Noobs. Dimana balenaEtcher atau etcher merupakan utilitas gratis dengan source code yang digunakan untuk menulis file yang bersumber *.iso, *.img ke dalam micro SD, SSD atau UFD. Dimana ethcer ini dikembangkan oleh kerangka electron dengan lisensi dibawah Apache 2.0 yang mampu mendukung multi platform seperti Windows, macOS, linux dan perangkat System on Chip (SoC) Sedangkan Noobs (New Out of Box Software), merupakan software pengelola instalasi beberapa sistem operating yang nantinya dimasukan kedalam sebuah perangkat segala produk turunan dari Raspi, mulai dari sistem operasi Debian, Raspberry OS, Ubuntu Server, Ubuntu Core, Ubuntu MATE, BerryWebServer, MozilaWebThings, dan Windows IoT. 


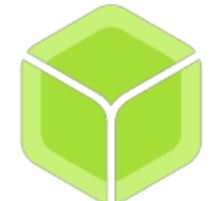

Gambar 2.5

Software pendukung balenaEtcher

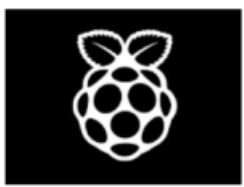

Gambar 2.6

Software pendukung Noobs

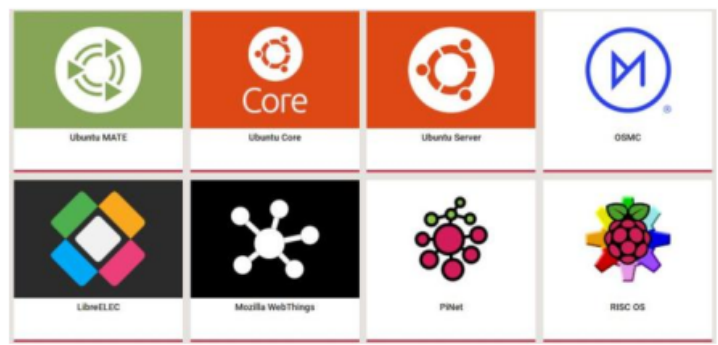

Gambar 2.7

Operating Sistem yang dapat diinstall

\subsection{3. balenaEtcher}

Balena atau balenaEtcher merupakan aplikasi gratis dan opensource yang berfungsi membuat kartu SD (micro SD) dan flash drive USB atau bootable di flasdisk, balena mendukung di wondows, masOS, dan linux bertujuan untuk perangkat yang lebih kecil berupa Raspberry Pi. BlenaEtcher memudahkan penerapan kode dari suatu sourcecode agar dapat terektrak kedalam perangkat berupa Micro SD atau UFD sehingga dapat terhubung. Dimana balenaEtcher mampu mengoptimalisasikan paradigma cloud untuk perangkat jarak jauh, bangunan yang kustom keandalan tinggi, dan dukungan siap pakai di berbagai perangkat.

Dengan keungulan beberapa perintah sederhana, berbagai operating system yang dapat membantu anda dalam memantau, mengelola, dan memperbarui perangkat dari mana saja termasuk konfigurasi variabel, variabel layanan, akses SSH, dan log perangkat. Selain daripada itu bukan hanya source code dari keluarga linux, namun balenaEtcher mampu mengestrak source code dari keluarga Windows yang dikenal pemilih dari segi instalasi source code. 


\subsubsection{Storage / Media Penyimpanan.}

Semenjak era floopy sudah dirasa sudah tertinggal dan era Compact Disk sebagai penganti media penyimpanan, hadir penganti yang mulai bervariatif dari DVD dengan kapasitas penyimpanan 4,3 GB ataupun dengan 8,5 GB dengan kemampuan Double Layer. Belum lagi tempat penyimpanan baru berupa Kepingan. Blue Ray dengan kapasitas yang lebih besar daripada media penyimpanan keping sebelumnya.

Saat ini media penyimpanan saat ini sudah lebih bervariatif lagi, salah satu diantaranya yaitu SSD (Solid State Drive) dan MMC (Multi Media Card). Dimana SSD (Solid State Drive) merupakan teknologi penyimpanan yang berbasis Flash Nand. Dimana SSD ini memiliki keunggulan berupa tahan dari goncangan, bekerja tanpa suara karena menggunakan Flash Nand, dan memiliki waktu akses lebih cepat dan memliki latensi (waktu yang dibutuhkan sebuah data dari tempat asal ke tempat tujuan dengan hitungan milidetik) yang lebih rendah yang berbeda dari pendahulunya yaitu HDD. Akan tetapi SSD ini masih dirasa lebih mahal daripada pendahulunya.

Sedangkan MMC (Multi Media Card), merupakan kartu memori yang digunakan berbasis Solid-State yang diperkenalkan pada tahun 1997 oleh SanDisk dan Siemens AG dengan pengunaan pin yang rendah. MMC beroperasi sebagai media penyimpanan dengan perangkat portable yang dapat dibongkar pasang dan dapat diakses oleh Personal Computer, semisalnya dengan perangkat Kamera Digital, PDA dan Smartphone berbasis Android.

Era kini pengguna semakin cerdas dalam memilih akan kebutuhan, ukuran, kemudahan, kapasitas, serta ekonomis dirasa menjadi pilihan dan mudah dalam pengunaanya yang hanya "Plug and Play". 


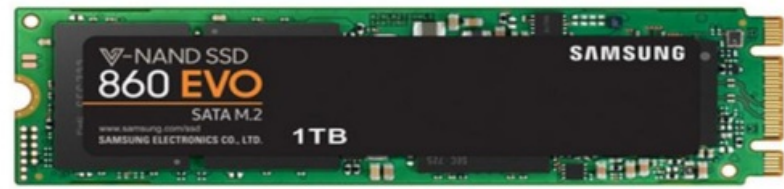

Gambar 2.8

SSD Jenis M.2

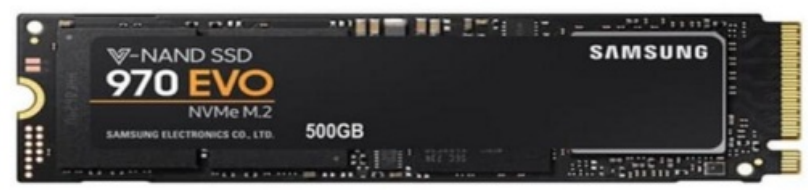

Gambar 2.9

SSD Jenis NVMe M.2

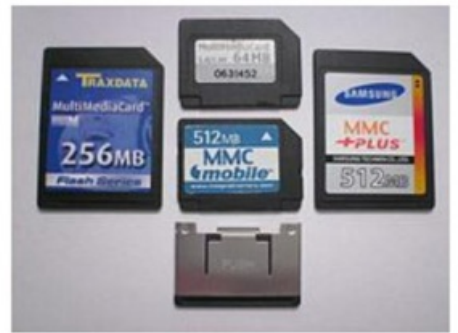

Gambar 2.10

Jenis MMS dan Adapter

\subsubsection{OMV (Open Media Vault)}

OMV (Open Media Vault) merupakan bentuk revolusi dari sebuah generasi NAS (Network Attached Storage) dari sebuah turunan linux Debian. Dimana OMV tersebut memiliki layanan seperti Operating Sistem keluarga Windows, OS X, iOS, Unix, Linux. Didalam OVM, terdapat sekali fitur lintas platform mulai AFP (Apple File Protokol), CIFS (Common Internet File System), FTP (File Transfer Protokol), LDAP (Light Weight Directory Access Protokol), iSCI (Internet Smal Computer Sistem Interface), Samba (File Transfer Protokol pada operating sistem Unix). SSH (Secure Shell Connection), S-FTP (Secure-File Transfer Protocol), SMB/CIFS (Server Message Block/Common Internet File System), DAAP (Digital Audio Access Protocol-Media Server), Rsycn, BitTorent. 
OMV dibangun dan didesain dalam bentuk yang sederhana mungkin dan dapat diperuntukan dalam untuk SOHO (Small Offices and Home Offices) dan memungkinkan semua orang bisa mengkonfigurasi, menginstall dan mengatur NAS (Network Attached Storage) sesuai kebutuhan tanpa harus memiliki background informatika atau teknik secara umum.

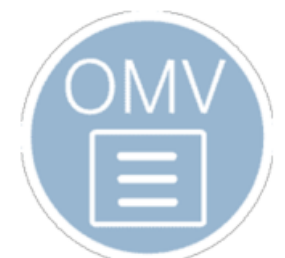

Gambar 2.11

Logo Open Media Vault

Linux Open Media Vault tersebut mendukung dengan infrastruktur ARM dengan x86 dan x64 bit. Keunggulan dari Linux Free Nas ini adalah mempunyai interface berbasis webbrowser dan dapat dikendalikan menggunakan $S S H$ (jika fitur tersebut diaktifkan). Selain itu, sistem ini didesain modular dan mudah disebarluaskan dengan plugin pihak ketiga melalui Repositori OMV-Extras.

\subsubsection{Server}

Server adalah sebuah sistem komputer yang menyediakan jenis layanan tertentu dalam sebuah jaringan komputer. Terkadang istilah server disebut sebagai webserver. Namun umumnya orang lebih suka menyebutnya sebagai server saja. Sebuah server didukung dengan prosesor yang bersifat scalable dan RAM yang besar, juga dilengkapi dengan sistem operasi khusus. Sistem operasi ini berbeda dengan sistem operasi yang biasanya. Jika kita biasa menggunakan sistem operasi Windows, MacOS, Linux, dan Unix maka sistem operasi dari server ini mungkin berbeda. Sistem Operasi dari server adalah sistem operasi jaringan (Network Operating System). Server juga bertugas untuk menjalankan software administratif, yakni software yang mengontrol akses terhadap jaringan dan sumber daya yang terdapat di 
dalamnya. Hal ini termasuk file atau alat pencetak (printer), dan memberikan akses kepada workstation anggota jaringan. (Amif, 2008).

Di dalam sistem operasi server, umumnya terdapat berbagai macam service yang menggunakan arsitektur klien/server. Contoh dari service yang diberikan oleh server ini antara lain Mail Server, DHCP Server, HTTP Server, DNS Server, FTP Server dan lain lain. Setiap sistem operasi server umumnya merangkai berbagai layanan tersebut. Atau bisa juga layanan tersebut diperoleh dari pihak ketiga. Setiap layanan tersebut akan merespons terhadap request dari klien. Saat ini sistem yang cukup populer adalah Windows 2000, 2003, 2012 Server, kemudian Sun Solaris, Unix, dan GNU/Linux. Pada umumnya, sebuah server terhubung dengan client dengan kabel UTP dan sebuah Network Card. Kartu jaringan ini biasanya berupa kartu PCI atau ISA. (Mahmud, 2002).

\subsubsection{Putty}

Putty adalah sebuah program open source yang dapat di gunakan untuk melakukan protokol jaringan SSH dan telnet. Protokol ini dapat digunakan untuk menjalankan sesi remote pada sebuah komputer melalui sebuah jaringan, baik itu LAN maupun internet (Budi, 2013).

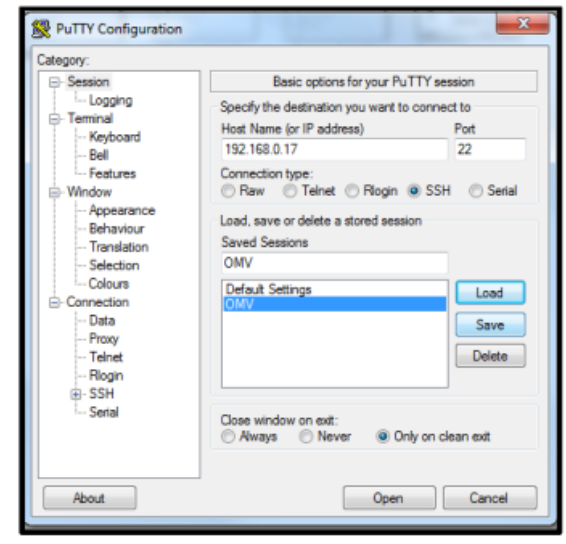

Gambar 2.12 Tampilan Putty 


\subsubsection{Management User}

Dalam sistem operasi linux khusunya Open Media Vault diperlukan juga yang namanya management user dan grup. Management user sangat diperlukan agar lebih mudah mengontrol apa bila ada user yang membuat akun baru atau mengganti password.

Management user dan accont termasuk pekerjaan administrasi sistem yang biasa dilakukan dari hari ke hari oleh seorang administrator sistem. Pekerjaan yang tercakup didalamnya cukup komplek dan administrator sistem dituntut untuk betul - betul menguasainya.

Dengan adanya management user dan grup ini akan memudahkan dalam setiap membagi akun user pada masing - masing grup. Management user juga mengatur hak kepemilikan file pada masing - masing user (Rafiudin, 2004).

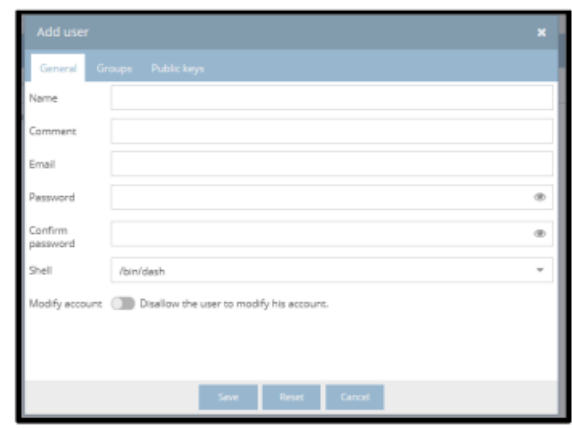

Gambar 2.13 Manajement grup pada Open Media Vault

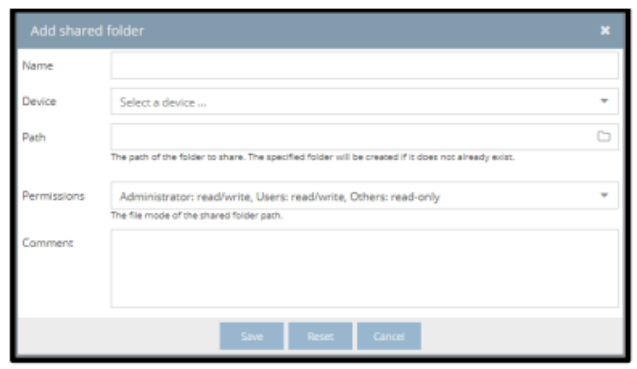

Gambar 2.14 Penambahan folder user 


\subsubsection{Access Point}

Access Point adalah sebuah perangkat jaringan yang berisi sebuah transceiver dan antena untuk transmisi dan menerima sinyal ke dan dari clients remote. Dengan access points (AP) clients wireless bisa dengan cepat dan mudah untuk terhubung kepada jaringan LAN kabel secara wireless. (Sanha. 2015).

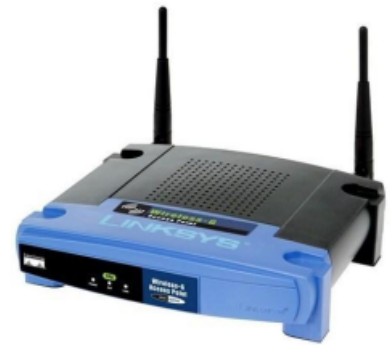

Gambar 2.15 Perangkat keras access point

\subsubsection{Hub Switch}

Switch adalah suatu jenis komponen jaringan komputer yang digunakan untuk menghubungkan beberapa HUB dalam membentuk jaringan komputer yang lebih besar atau menghubungkan komputerkomputer yang memiliki kebutuhan akanbandwidth yang cukup besar.

Beberapa fungsi switch yaitu sebagai manajemen lalu lintas yang terdapat pada suatu jaringan komputer, switch bertugas bagaimana cara mengirimkan paket data untuk sampai ke tujuan dengan perangkat yang tepat, Switch juga bertugas untuk mencari jalur yang paling baik dan optimal serta memastikan pengiriman paket data yang efisien ketujuannya. (Sora, 2015).

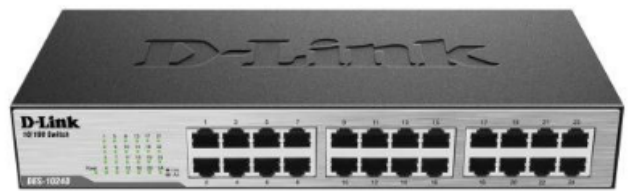

Gambar 2.16 Perangkat keras hub swicth 


\subsubsection{Docking Station}

Docking station juga dikenal sebagai Universal Port Replicator, berfungsi sebagai konverter sekaligus tempat pengubah fungsi dari SATA menjadi USB veri 3.0. Dimana SATA yang tersedia berisikan 2 Slot atau Dual Bay ukuran 3.5 Inchi dan 2.5 Inchi plus adaptor output $12 \mathrm{~V}, 3 \mathrm{~A}$, dan $36 \mathrm{~W}$.

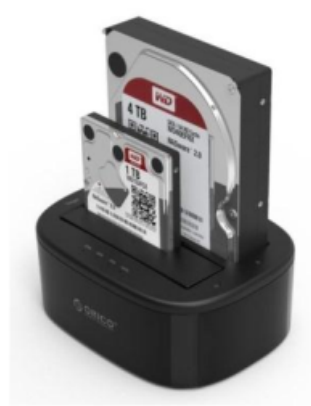

Gambar 2.17 Perangkat keras docking station

\subsubsection{Daftar Simbol}

\section{a. Flowmap}

Flowmap adalah sebuah pengambaran secara grafik dari sebuah langkah-langkah maupun urut-urutan dari proses prosedur dari suatu rancang bangun secara logika. Flowmap ini berfungsi untuk memodelkan suatu nilai inputan ataupun output maupun proses transaksi dengan menggunakan sebuah simbol-simbol tertentu. Pembuatan flowmap ini dapat memudahkan bagi pemakai, pengelola, dan pengembang dalam memahami alur dari sebuah suatu rancangan. Berikut ini merupakan simbol-simbol dalam flowmap pada tabel berikut ini.

Tabel 2.2 Daftar simbol flowmap (Sakinah, 2002)

\begin{tabular}{|c|c|l|}
\hline Simbol & \multicolumn{1}{|c|}{ Nama } & \multicolumn{1}{c|}{ Keterangan } \\
\hline & $\begin{array}{c}\text { Terminator awal / } \\
\text { akhir program }\end{array}$ & $\begin{array}{l}\text { Untuk memulai dan } \\
\text { mengakhiri suatu } \\
\text { program }\end{array}$ \\
\hline & Dokumen & $\begin{array}{l}\text { Menunjukkan } \\
\text { dokumen berupa input } \\
\text { dan output }\end{array}$ \\
\hline
\end{tabular}




\begin{tabular}{|c|c|c|}
\hline & Proses Manual & $\begin{array}{l}\text { Menunjukkan proses } \\
\text { yang dilakukan secara } \\
\text { manual. }\end{array}$ \\
\hline & Proses Komputer & $\begin{array}{l}\text { Menunjukkan proses } \\
\text { yang dilakukan secara } \\
\text { komputerisasi }\end{array}$ \\
\hline & Arah aliran data & $\begin{array}{l}\text { Menunjukkan arah } \\
\text { aliran antar bagian } \\
\text { terkait sistem. }\end{array}$ \\
\hline & Penyimpanan manual & $\begin{array}{lc}\text { Menunjukkan } & \text { media } \\
\text { penyimpanan } & \text { data } \\
\text { infomasi } & \text { secara } \\
\text { manual } & \end{array}$ \\
\hline & Data & $\begin{array}{lr}\text { Simbol } & \text { input/output } \\
\text { digunakan } & \text { untuk } \\
\text { mewakili } & \text { data } \\
\text { masukan } & \\
\end{array}$ \\
\hline & File Harddisk & $\begin{array}{l}\text { Media penyimpanan } \\
\text { dari proses entry data } \\
\text { dan proses } \\
\text { komputerisasi }\end{array}$ \\
\hline & Keyboard & $\begin{array}{l}\text { Proses penyimpanan } \\
\text { menggunakan } \\
\text { keyboard }\end{array}$ \\
\hline
\end{tabular}

1

b. Block Diagram

Block diagram ialah sebuah sistem dimana bagian utama diwakili oleh blok, yang terpisah dan terhubung dengan sebuah garis. Dimana block diagram ini dipergunakan dalam dunia hardware, desain elektronik, software desain, dan proses aliran diagram. Berikut ini daftar simbol block diagram antara lain ;

Tabel 2.3 Daftar simbol block diagram (Taufik, 2005)

\begin{tabular}{|c|c|l|}
\hline Simbol & \multicolumn{1}{|c|}{ Nama } & \multicolumn{1}{|c|}{ Keterangan } \\
\hline & Block / kotak & $\begin{array}{l}\text { Biasanya berisikan } \\
\text { uraian, nama elemen, } \\
\text { simbol untuk operasi } \\
\text { matematis. }\end{array}$ \\
\hline$\longleftarrow$ & Tanda anak panah & $\begin{array}{l}\text { Menyatakan arah } \\
\text { informasi aliran isyarat }\end{array}$ \\
\hline
\end{tabular}




\section{c. Flowchart}

Flowchart atau bagian alir menunjukan dimana didalam program atau prosedur sistem secara logika. Dimana bagan alir digunakan untuk alat bantu komunikasi serta dokumentasi. Berikut ini beberapa daftar simbol flowchart antara lain;

Tabel 2.4 Daftar simbol flowchart (Kristanto, 2003)

\begin{tabular}{|c|c|c|}
\hline Simbol & Nama & Keterangan \\
\hline & Terminator & Start / Finish \\
\hline & Flow Line & Arah aliran program \\
\hline & Preparation & $\begin{array}{l}\text { Proses Inisialisasi atau } \\
\text { pemberian harga awal }\end{array}$ \\
\hline & Proses & $\begin{array}{l}\text { Proses perhitungan } \\
\text { atau proses } \\
\text { pengolahan data }\end{array}$ \\
\hline & Input/output & $\begin{array}{l}\text { Proses input atau } \\
\text { output data, parameter } \\
\text { dan informasi }\end{array}$ \\
\hline & Predefined Proses & $\begin{array}{lr}\text { Permulaan } & \text { sub } \\
\text { program atau } & \text { proses } \\
\text { menjalankan } & \text { sub } \\
\text { program } & \end{array}$ \\
\hline & Decision & $\begin{array}{l}\text { Penyeleksian data } \\
\text { yang memberikan } \\
\text { pilihan guna langkah } \\
\text { berikutnya }\end{array}$ \\
\hline & On Page Connector & $\begin{array}{l}\text { Penghubung bagian } \\
\text { flowchart yang ada } \\
\text { pada satu halaman }\end{array}$ \\
\hline & Off Page Connector & $\begin{array}{l}\text { Penghubung bagian } \\
\text { flowchart yang ada } \\
\text { pada halaman berbeda }\end{array}$ \\
\hline
\end{tabular}

\subsubsection{Topologi Jaringan}

Topologi jaringan menyatakan susunan komputer secara fisik dalam suatu jaringan. Berbagai kemungkinan topologi : bintang, cincin, bus, pohon, hybrid dan tidak beraturan. 


\section{a. Topologi Bintang (Star)}

Pada topologi ini terdapat komponen yang bertindak sebagai pusat pengontrol. Semua simpul yang hendak berkomunikasi selalu melalui pusat pengontrol tersebut berupa hub. Kelebihan topologi bintang yaitu:

1. Mudah dikelola dan dihubungkan (penyebab kegagalan mudah diketahui).

2. Kegagalan pada sebuah komputer tidak berpengaruh pada seluruh jaringan.

Kelemahan topologi bintang yaitu:

1. Kegagalan pada pusat pengontrol akan menyebabkan kegagalan jaringan secara keseluruan.

2. Jika pusat pengontrol berupa hub (bukan berupa swicth) maka kecepatan transmisi menjadi lambat.

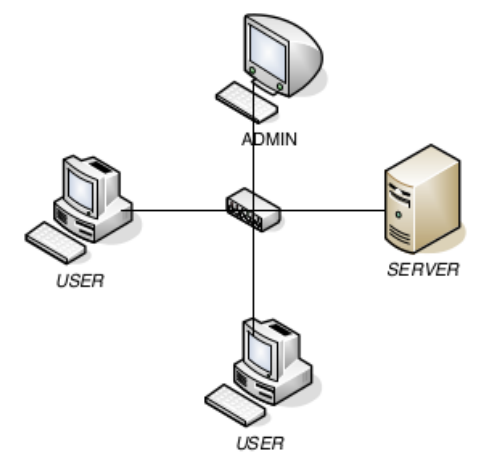

Gambar 2.18 Topologi Bintang

\section{b. Topologi Cincin (Ring)}

Topologi cincin mirip dengan topologi bus. Informasi dikirim oleh sebuah komputer dan akan dilewatkan ke media transmisi melalui satu komputer ke komputer berikutnya. 


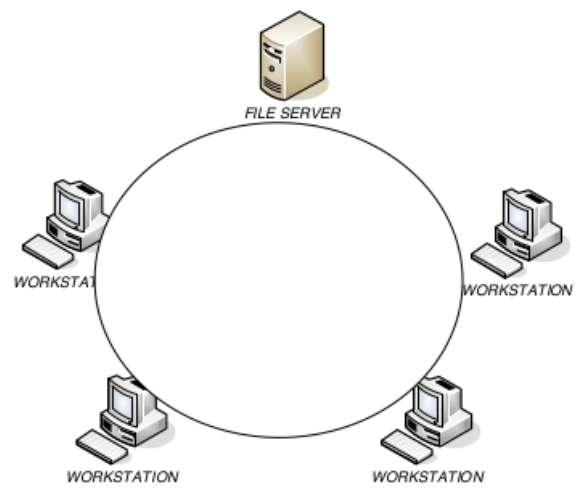

Gambar 2.19 Topologi Cincin (Ring)

Kelemahan topologi cincin terletak pada kegagalan salah satu simpul. Jika ada satu saja simpul yang mengalami kegagalan maka semua hubungan terputus. Pada topologi bus kegagalan pada simpul (bukan pada bus) tidak mempengarui simpul yang lain.

\section{c. Topologi Bus}

Pada topologi bus semua simpul (umumnya komputer) dihubungkan melalui kabel yang disebut bus. Kabel yang digunakan adalah kabel koaksial. Jika user mengirimkan pesan ke user lain maka pesan tersebut melalui bus.

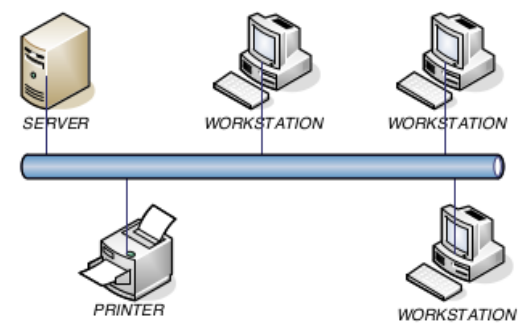

Gambar 2.20 Topologi Bus

Kelebihan topologi bus yaitu:

1. Instalasi mudah.

2. Biaya murah. 
Kelemahan topologi bus yaitu:

1. Jika kabel utama (bus) putus, maka semua komputer tidak bisa saling berhubungan.

2. Jika kabel utama sangat panjang dan terdapat gangguan, pencarian penyebab masalah menjadi sulit.

3. Jika banyak komputer yang aktif (mengirim pesan) akan sering terjadi tabrakan sehingga mengakibatkan kecepatan pengiriman data menjadi berkurang.

Topologi bus biasanya digunakan untuk LAN dengan jumlah komputer yang sedikit. Misalnya dapat digunakan di warnet.

\section{d. Topologi Tree / Pohon}

Topologi pohon sebenarnya merupakan pengembangan dari topologi bintang dengan salah satu simpul menjadi pengontrol bagi sejumlah simpul yang berada di bawahnya.

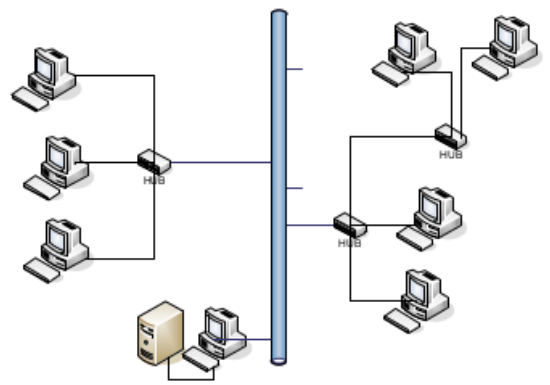

Gambar 2.21 Topologi Tree / Topologi Pohon

\section{e. Topologi Hybrid}

Topologi hybrid yaitu kombinasi dari dua atau lebih topologi berbeda berpadu menjadi satu bentuk baru pada jaringan komputer atau topologi berbeda terhubung kesatu sama lain dan tidak menampilkan satu karasteristik topologi tertentu. 


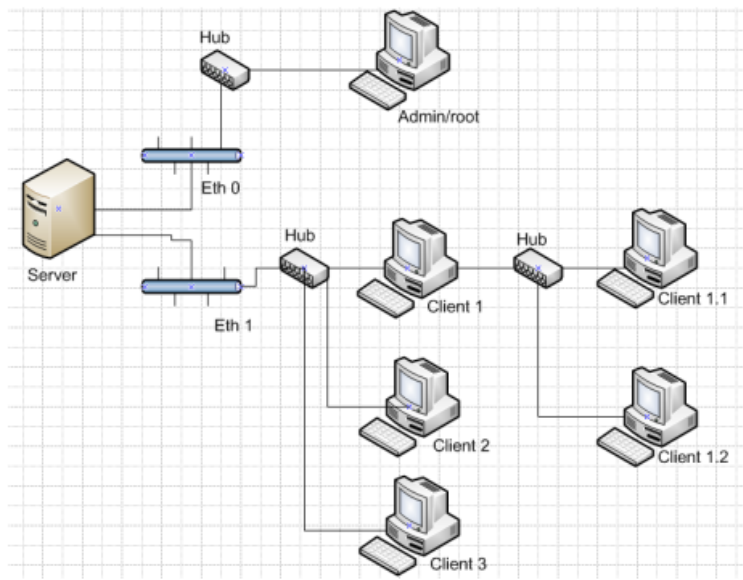

Gambar 2.22 Topologi Hybrid

Kelebihan topoogi hybrid yaitu:

1. Fleksibel.

2. Menambahkan koneksi perifer lain cukup mudah.

3. Memiliki toleransi kesalahan yang lebih baik.

4. Kecepatan topologi konsisten.

5. Sangat efisien.

Kelemahan topologi hybrid yaitu:

1. Pengolahan topologi akan menjadi lebih sulit.

2. Membutuhkan biaya yang lebih dibanding topologi yang lain.

3. Instalasi dan konfigurasi yang sulit.

\section{f. Topologi tidak beraturan (Mesh)}

Topologi mesh adalah gambaran langsung antara perangkat satu dengan perangkat lainnya dimana dibangun dengan memasang link diantara stasiun-stasiun. Topologi mesh merupakan topologi yang tidak memiliki aturan dalam koneksinya. 


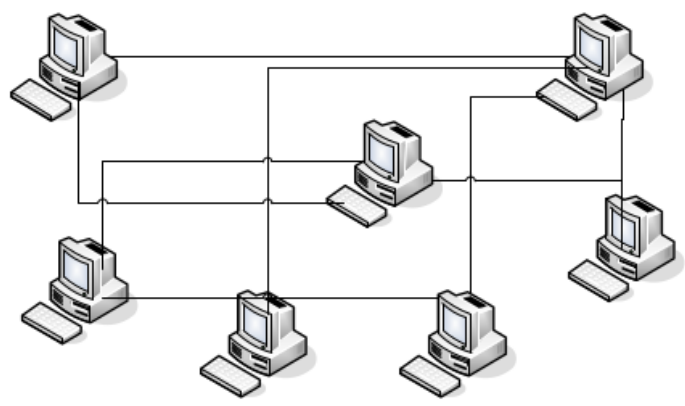

Gambar 2.23 Topologi Mesh

Kelebihan topologi mesh yaitu:

1. Data dapat dikirimkan langsung ke komputer tujuan tanpa melalui komputer lainnya.

2. Bila terjadi gangguan tidak akan mempengarui koneksi lainnya.

3. Keamanan lebih terjamin.

Kelemahan topologi mesh yaitu:

1. Butuh banyak kabel dan port input output.

2. Instalasi dan konfigurasi lebih sulit.

3. Memerlukan space yang lebih besar.

(Kadir, 2006) 


\section{BAB III}

\section{METODOLOGI PENELITIAN}

\subsection{Jenis Penelitian}

Dalam membuat dan melakukan penelitian ini, jenis penelitian yang digunakan adalah Simulation, Design and Creations. Jenis Penelitian ini dipilih dikarenakan konsep dari Simulation, Design and Creation sangat cocok untuk penelitian ini disamping melakukan rancang bangun tentang judul "Rancang Bangun dan Implementasi Penyimpanan File Server Berbasis IoT Dengan Raspberry Pi 3b+ Menggunakan OMV", mengingat Raspberry Pi ini belum populer dikalangan dunia Informasi dengan teknologi IoT (Internet of Think).

\subsection{Pendekatan Penelitian.}

Penelitian ini menggunakan pendekatan saintifik berupa pendekatan berdasarkan ilmu pengetahuan, teknologi dan informasi serta Simulation, Design and Creation saat ini yang berkembang di dunia IoT (Internet of Think).

\section{3 ${ }^{1}$ Metode Pengumpulan Data}

Metode pengumpulan data dipakai dalam penelitian adalah studi literatur. Strudi literatur merupakan metode pengumpulan data dengan dengan cara membaca buku-buku, jurnal elektronik, paper, majalah elektronik, blog dan vlog yang sesuai dengan kebutuhan data terkait penelitian yang peneliti lakukan. 


\subsection{Bahan dan Alat Penelitian}

Dalam menyelesaikan laporan terakhir sebagai laporan skripsi ini penulis membutuhkan perangkat keras yang mendukung dan perangkat lunak yang menunjang dalam menyelesaikan laporan skripsi, antara lain ;

1. Perangkat keras dan lunak yang dibutuhkan dari sisi Raspberry sbb;

a. Perangkat keras dari sisi server Raspberry ;

i. Raspberry Pi 3 model b+ plus adapter 5 Volt

ii. Micro SD $16 \mathrm{~Gb}$ Class $10 \mathrm{HC}$ untuk operating system

iii. Docking station 2 bay Orico dengan USB 3.0 plus adapter 12 volt

iv. HDD 3.5 inch kapasitas $160 \mathrm{~Gb}$ dan $80 \mathrm{~Gb}$ jenis Seagate Sata III

v. SSD V-Gen $512 \mathrm{~Gb}$ jenis M.2 plus converter M.2 to Sata III ukuran 2.5 inch

vi. Micro SD $32 \mathrm{~Gb}$ dan $10 \mathrm{~Gb}$ Class $10 \mathrm{HC}$ plus Card Reader

vii. Monitor + kabel HDMI

b. Perangkat lunak dari sisi server Raspberry ;

i. Open Media Vault versi 3.079 (versi Eramus) support Raspberry model $3 \mathrm{~b}+$ nama file “OMV_3_0_99_RaspberryPi_2_3_4.9.80.img.xz”

2. Perangkat keras dan lunak yang dibutuhkan dari sisi administrator sbb;

a. Perangkat keras dari sisi administrator ;

i. Intel(R) Core(TM)2 CPU $6600 @ 2.40 \mathrm{GHz}$ (2 CPUs), 2.4GHz

ii. DDR3 8192 Mb RAM / @ 4096 Mb dua Keping

iii. NVIDIA GeForce G210 Dedicated Memory : $978 \mathrm{Mb}$

iv. SSD $256 \mathrm{~Gb}$ V-Gen Sata III

v. Mouse, Keyboard, Cardreader dan Monitor

vi. Qualcom Atheros Fast Ethernet Controler Lan 100 Mbps dan TP-Link Wifi adapter $20-40 \mathrm{Mhz}$ 
b. Perangkat lunak dari sisi administrator ;

i. Operating System Windows 7

ii. Mozilla Firefox / Chrome

iii. Putty

iv. balenaEtcher Portable

v. SD Card Formatter

vi. File Zilla atau WinSCP

c. Jaringan internet

i. Cisco DPC2320

ii. TP-Link TL-MR 3420

iii. Kabel kategori 5e

3. Perangkat keras \& lunak yang dibutuhkan dari client atau pengguna sbb ;

a. Perangkat keras dari sisi pengguna ;

i. Intel(R) Core(TM)2 CPU $6600 @ 2.40 \mathrm{GHz}$ (2 CPUs), 2.4GHz

ii. DDR3 8192 Mb RAM / @ 4096 Mb dua Keping

iii. NVIDIA GeForce G210 Dedicated Memory : $978 \mathrm{Mb}$

iv. SSD $256 \mathrm{~Gb}$ V-Gen Sata III

v. Mouse, Keyboard, Cardreader dan Monitor

vi. Qualcom Atheros Fast Ethernet Controler Lan 100 Mbps dan TPLink Wifi adapter $20-40 \mathrm{Mhz}$

b. Perangkat lunak dari sisi pengguna ;

i. Ubuntu versi 20.10 Desktop/AMD x86/64

4. Perangkat keras \& lunak yang dibutuhkan dari client berupa smartphone ;

a. Perangkat keras dan lunak dari sisi pengguna ;

i. iPhone 5S dengan iOS 12.5.1 


\subsection{Teknik Pengumpulan Data.}

Teknik yang digunakan untuk menyelesaikan laporan skripsi ini menggunakan beberapa teknik instrumen penelitian yang digunakan berupa :

\section{a. Metode Simulation}

Menurut Abu Ahmadi simulasi (simulation) berarti tiruan atau suatu perbuatan yang bersifat pura-pura saja. Sebagai metode pengajaran, simulasi dapat diartikan sebagai suatu kegiatan yang menggambarkan keadaan sebenarnya. Jadi user atau pengguna melakukan peranan dalam simulasi tiruan untuk mencoba atau menggambarkan kejadian yang sebenarnya. Maka didalam kegiatan simulasi, peserta atau user memiliki peranan melakukan tiruan dari kejadian yang sebenarnya. Dalam metode simulasi yang merupakan metode suatu peniruan terhadap sesuatu yang nyata, terhadap keadaan sekelilingnya (state of affaris) atau proses.

Berdasarkan beberapa pendapat yang dikemukakan oleh beberapa oleh beberapa ahli tersebut, dapat dipahami bahwa metode simulasi merupakan suatu model pembelajaran yang dilaksanakan oleh pengelola dengan cara penyajian, pengalaman pengunaan dengan menggunakan situasi tiruan untuk memahami tentang konsep, prinsip, atau keterampilan tertentu..

\section{b. Metode Design dan Creation}

Pada metode design and creation, dalam buku berjudul "Researching Information Systems and Computing" yang ditulis oleh Briony J Oates (2005) menjelaskan bahwa design and creation merupakan penggabungan antara metodologi penelitian dan metodologi pengembangan aplikasi. Metode ini menggunakan proses literatif yang terdiri dari lima langkah, yaitu Awarness, Sugestion, Development, Evaluation, dan Conclusion (Vaishnavi \& Kuechler, 2004). 


\subsection{Metode Kerangka Penelitian.}

Dalam menyelesaikan rancang bangun dalam penelitian diatas, metode perencanaan aplikasi yang digunakan adalah Waterfall dan Design and Creation Metode Watefall ini merupakan model klasik yang bersifat berurutan dan sistematis dalam merancang bangun dan implementasi penyimpanan file server berbasis IoT dengan Raspberry PI 3B+, dimana dalam proses pengerjaanya bertahap dan harus menunggu tahap sebelumnya selesai dilaksanakan sebelum kemudian melangkah ke tahapan selanjutnya.

Metode ini dipilih oleh penulis dikarenakan proses perancangan aplikasi dilakukan tahap demi tahap yang dimulai dari Requirements analysis and definition, System and Software design, Implementation, Integration, System Testing, Operation and Maintenance. (Pressman, 2001).

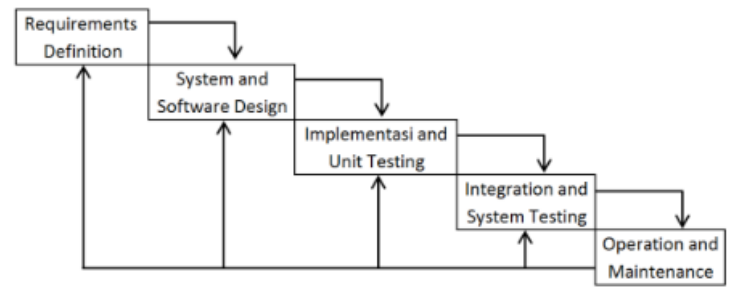

Gambar 3.1 Metode Kerangka Penelitian Model Waterfall

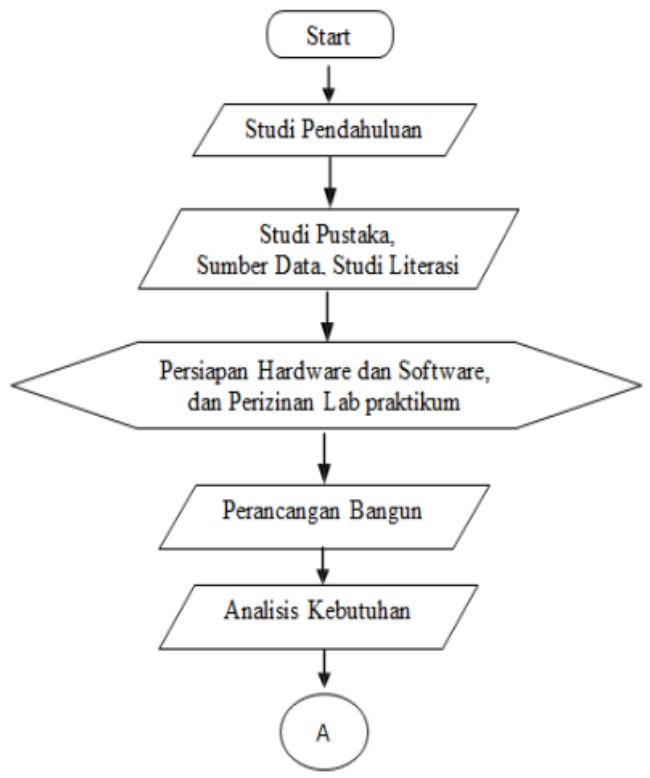




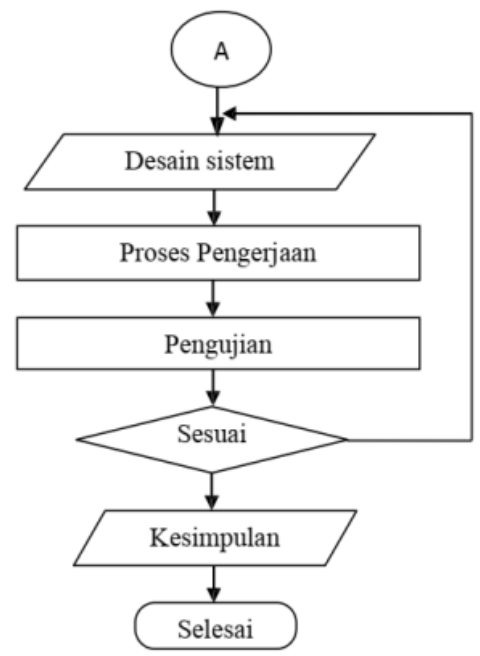

Gambar 3.2 Kerangka Penelitian Raspberry Pi 3b+

\subsection{Teknik Analisis dari Simulation, Design and Creations}

\subsubsection{Topologi Hybrid dengan Design and Creations.}

Topologi yang digunakan oleh penulis dalam implementasi gambar diatas menggunakan metode hybrid yang terdiri dari satu perangkat Raspberry Pi, Micro SD ukuran 32 Gb Class 10 Plus Reader, 1 set Docking dengan HDD ukuran 3.5 inch SATA III dengan kapasitas $160 \mathrm{~Gb}$ dan $80 \mathrm{~Gb}$, HDD 2.5 inch kapasitas $160 \mathrm{~Gb}$ jenis Toshiba plus converter to Sata III, SSD V-Gen 512 Gb jenis M.2 plus converter M.2 to sata III ukuran 2.5 inch. Dimana metode Hybrid atau metode design dan creation menggunakan beraneka macam jenis penyimpanan dari SSD, HDD hingga Micro SD.

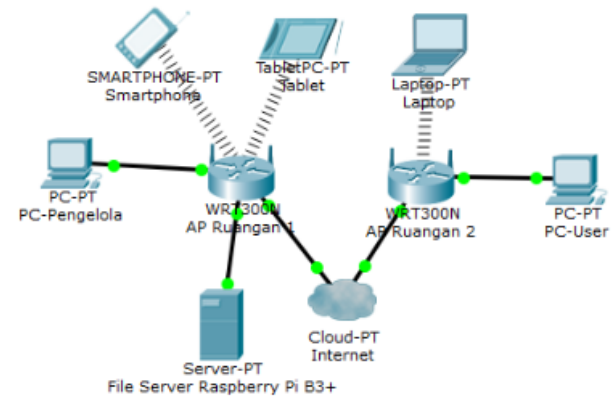

Gambar 3.3 Kerangka Metodologi Simulation, Design and Creations 


\subsubsection{Flowchart dari sisi Server}
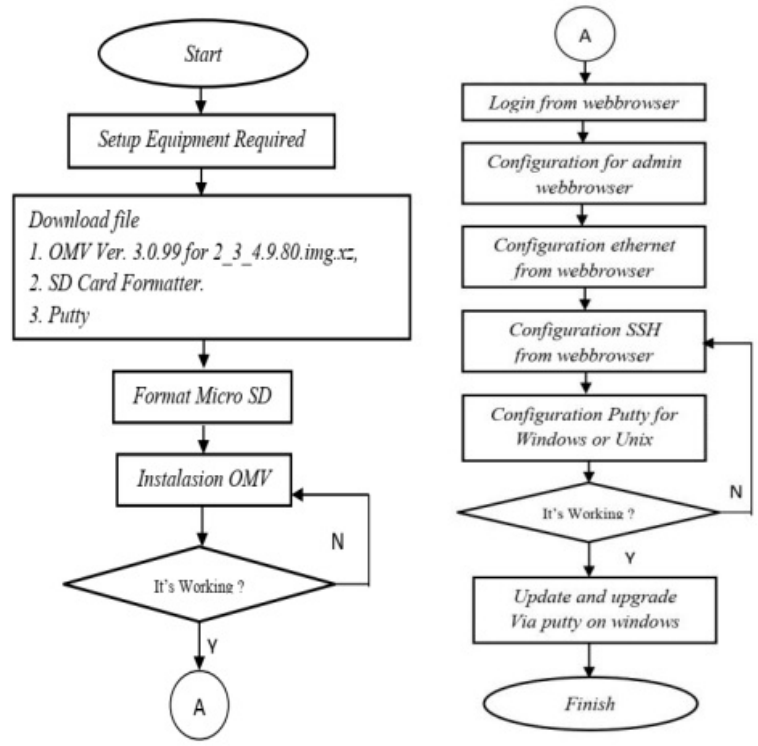

Gambar 3.4 Flowchart dari sisi Raspberry

\subsubsection{Flowchart dari sisi Superuser Level 0}

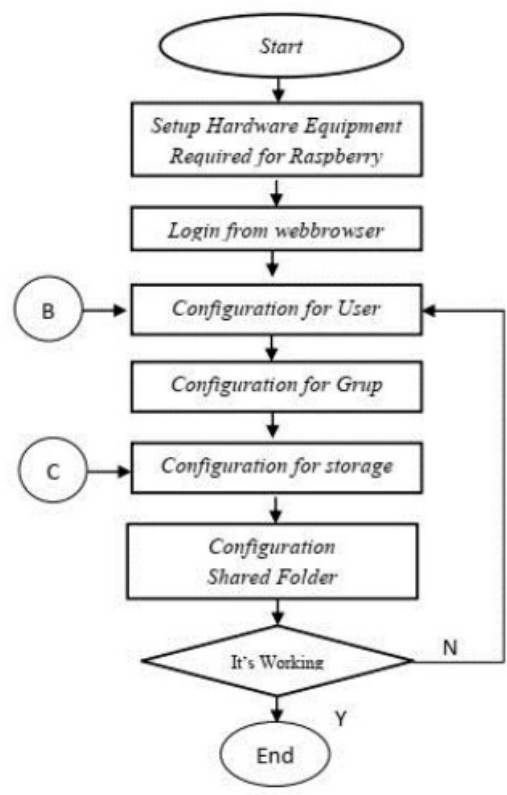

Gambar 3.5 Flowchart dari sisi Superuser Level 0 


\subsubsection{Flowchart dari sisi Pengguna Level 1}

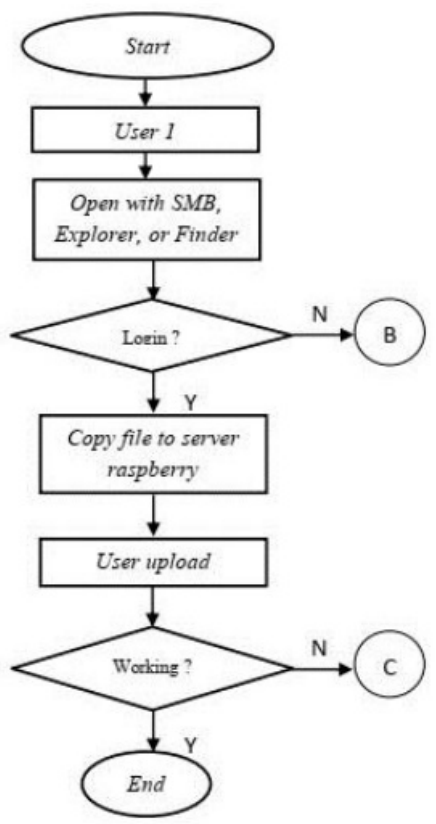

Gambar 3.6 Flowchart dari sisi Superuser Level 1 


\section{BAB IV}

\section{HASIL DAN PEMBAHASAN}

\subsection{Tahapan Implementasi IoT Raspberry}

Dari hasil rancang bangun dan implementasi penyimpanan file server berbasis IoT dengan Raspberry Pi $3 b+$ menggunakan OMV, Berjalan sesuai apa yang diharapkan oleh penulis. Dimana rancang bangun dan implementasi tersebut yang mengerucut pada layanan Samba (SMB), File Transfer Protokol (FTP). Dimana nantinya bisa dikembangkan menjadi layanan Rsync (Sinkronisasi) antara file asli dengan file penambahan.

\subsection{Tahapan Dasar Implementasi IoT Raspberry}

\subsubsection{Tahapan Instalasi OMV pada Raspberry Pi 3b+}

Proses awal mula Open Media Vault pada Raspberry Pi 3b+, dapat dilakukan sebagaimana langkah-langkah sebagai berikut ;

1. Download terlebih dahulu software pendukung, antara lain ;
a. 7zip.
e. OMV_3_0_99_RaspberryPi_2_3_4.
b. Sd formater 9.80.img.xz
c. Putty
f. File Zilla atau WinSCp
d. balenaEtcher

2. Masukan Micro SD 16 Gb kedalam Card reader kemudian pilih Quick Format.

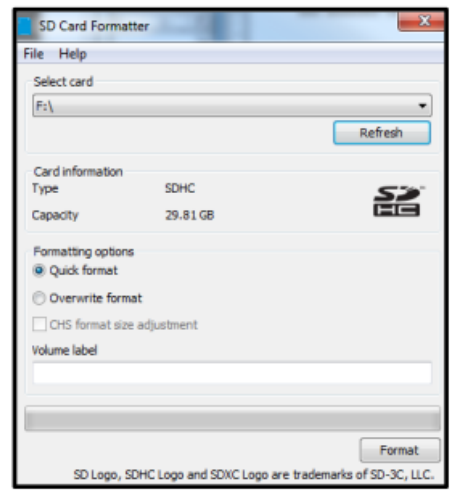

Gambar 4.1 Format Micro SD ke mode quick format 
3. Jalankan aplikasi "balenaEtcher", pilih file OMV_3_0_99, kemudian pilih lokasi direktori Micro SD yang terdapat pada langkah sebelumnya.

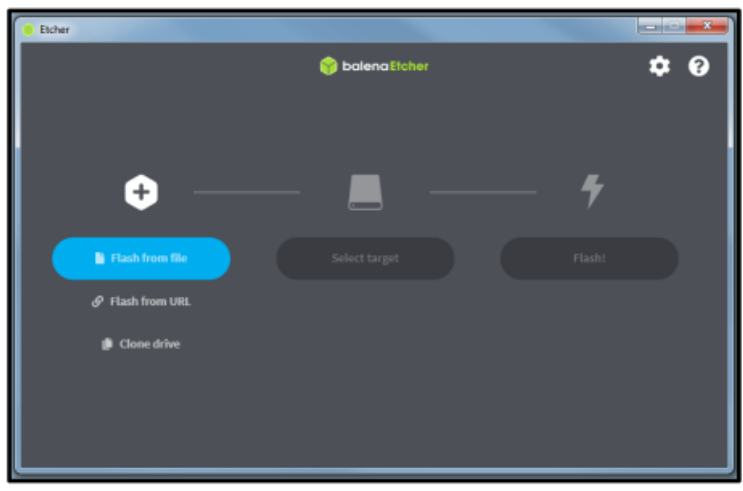

Gambar 4.2 Tampilan aplikasi balenaEtcher

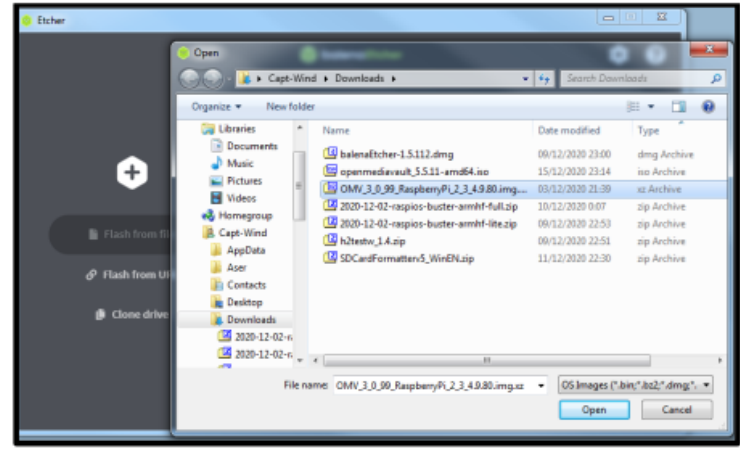

Gambar 4.3 Buka aplikasi Open Media Vault menggunakan balenaEtcher.

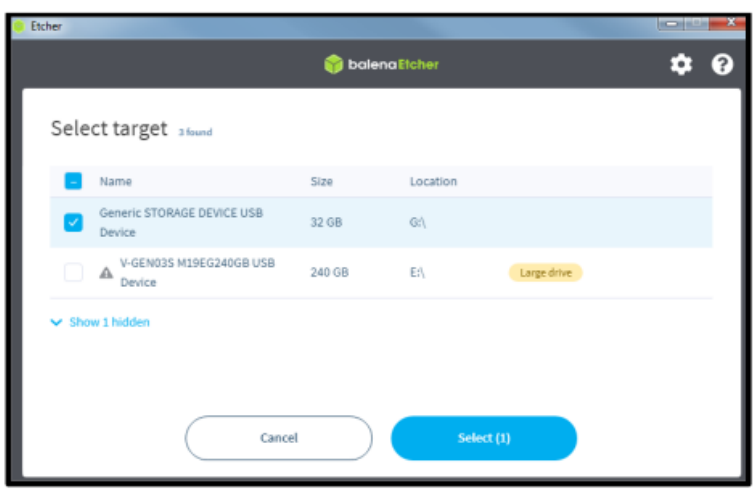

Gambar 4.4 Pilih lokasi Micro SD setelah itu lanjut. 


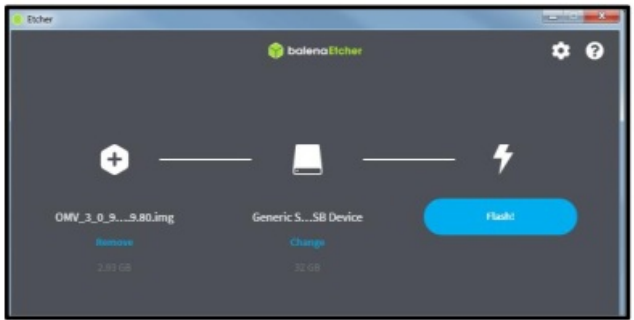

Gambar 4.5 Pilih flash untuk melakukan pada Micro SD

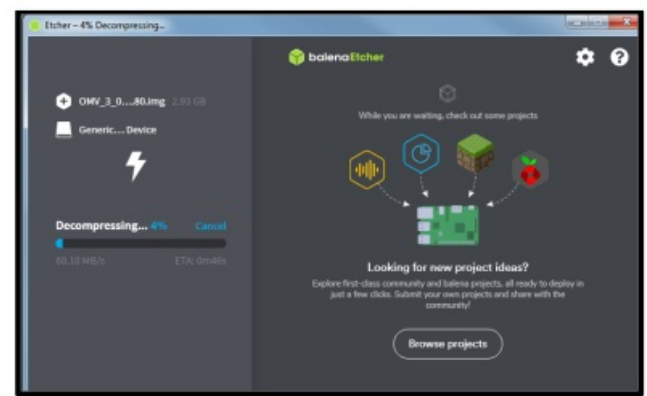

Gambar 4.6 Proses flasing sedang berlangsung

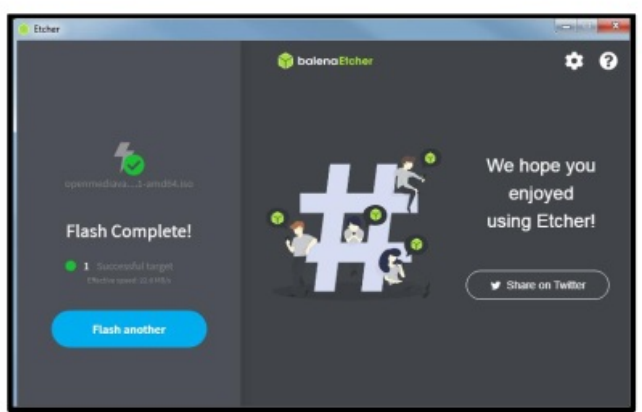

Gambar 4.7 Proses flasing sudah selesai

4. Masukan Micro SD yang sudah terinstall OMV_3_0_99, kedalam slot Micro SD Raspberry Pi 3b+ yang terletak dibagian bawah.

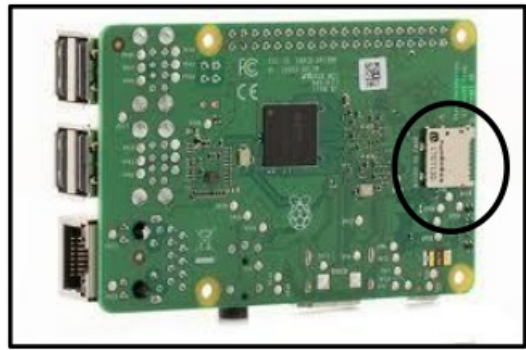

Gambar 4.8 Tampak bawah Micro SD Raspberry Pi 3b+ 
5. Setelah tertancap Micro SD ke perangkat Raspberry Pi jangan lupa nyalakan dan tancapkan kabel jaringan ke raspi. Sehingga bila dalam kondisi menyala akan tertampil mode teks sebagaimana tulisan dibawah ini.

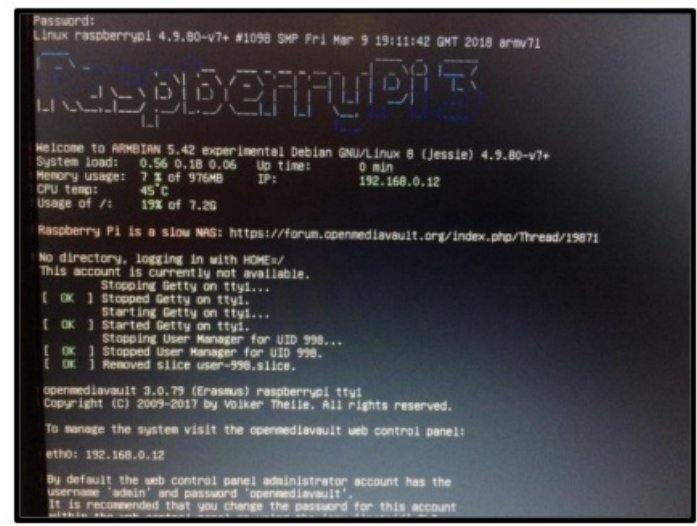

Gambar 4.9 Tampilan mode teks pada Open Media Vault

\subsubsection{Tahapan Configurasi OMV pada Raspberry Pi 3b+}

Setelah proses instalasi selesai, langkah selanjutnya ialah konfigursi mengunakan terminal. Konfigurasi ini bisa dilakukan menggunakan webbrowser atau menggunakan putty pada perangkat Windows. Kali ini penulis mengunakan putty untuk konfigurasi dan webbrowser untuk Graphic User Interface (GUI), sebagaimana langkah-langkah sebagai berikut ;

1. Setelah raspi kita sudah terhubung dalam suatu network, raspi kita secara DHCP mendapatkan IP secara acak dan mendapatkan nomor

IP 192.168.0.12 sebagaimana pada gambar sebelumnya.

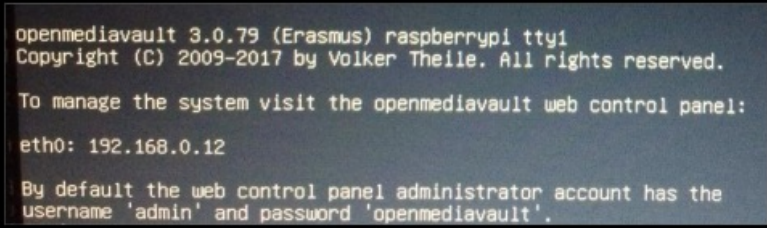

Gambar 4.10 Tampak tampilan versi Open Media Vault dan nomor alamat IP yang digunakan pada mode versi teks 
2. Setelah itu, buka browser dengan alamat sesuai dengan diatas dengan password yang sudah tertera pada langkah sebelumnya dimana "user $=$ admin" dengan "password = openmediavault". Setelah login, maka terdapat halaman informasi mengenai hostname, versi yang digunakan, prosesor, kernel, system time, load average, cpu usage, memori usage.

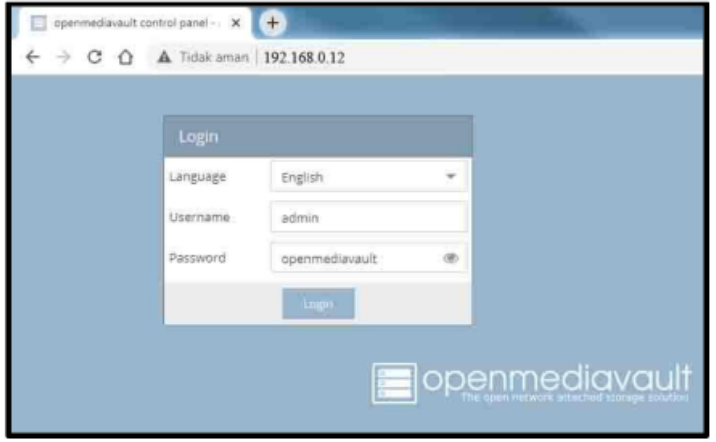

Gambar 4.11 Login dengan webbrowser untuk langkah awal konfigurasi Open Media Vault

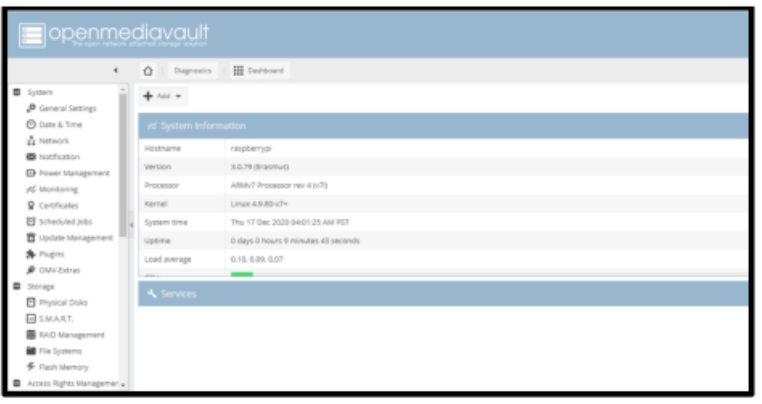

Gambar 4.12 Tampak halaman awal Open Media Vault

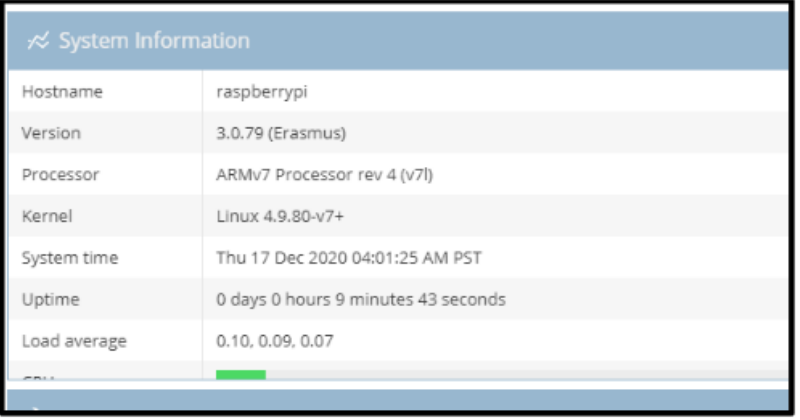

Gambar 4.13 Tampak lebih rinci halaman informasi mengenai kondisi sistem Open Media Vault 
Jika dijelaskan, versi mengenai prosesor yang digunakan bertuliskan ARMv7 prosesor rev 4 (v7) yang menjelaskan bahwa menggunakan teknologi SoC BCM2837 dimana ini merupakan prosesor Raspberry 3b+. Untuk versi dasar saat terinstall menggunakan versi 3.0.79 (eramus) dan versi terbaru versi 3.0.100 (eramus)

3. Langkah selanjutnya, merupakan konfigurasi hostname dengan cara, klik system kemudian General. Ganti hostname dan domain name sesuai dengan keinginan. Setelah itu klik save, dan apabila ada pemberitahuan "The configuration has been changed. You must apply the changes in order for them to take effect", klik Apply. Pemberitahuan tersebut selalu dilakukan bilamana ada perubahan konfigurasi sekecil apapun.

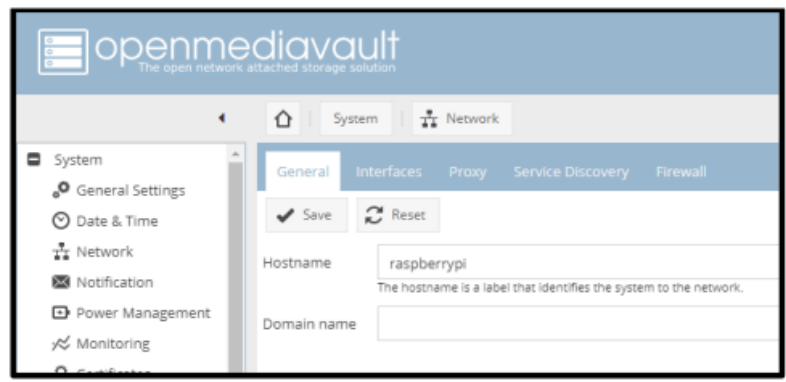

Gambar 4.14 Konfigurasi hostname dan domainname

The configuration has been changed. You must apply the changes in order for them to take effect. $\checkmark$ Apply $\supset$ Revert

Gambar 4.15 Tampilan notifikasi untuk pembaruan konfigurasi

4. Kemudian, kita lakukan perubahan password pada sisi "Web Administrator Password" dan "Session timeout" dimana nilai waktu dalam satuan menit jika Pengguna tidak mengakses mengakses halaman fungsi yang lain pada halaman yang sama, maka secara automatis logout dengan sendirinya. Hal ini untuk merubah konfigurasi bawaan dari Open Media Vault, itu sendiri. Dimana untuk perubahan nama klik General System, pilih Web Administrator kemudian ganti nilai 5 menjadi 0 . 
Selanjutnya untuk menganti Password dari sistem Open Media Vault menjadi sesuai keinginan sesuai kita sebagai administrator.

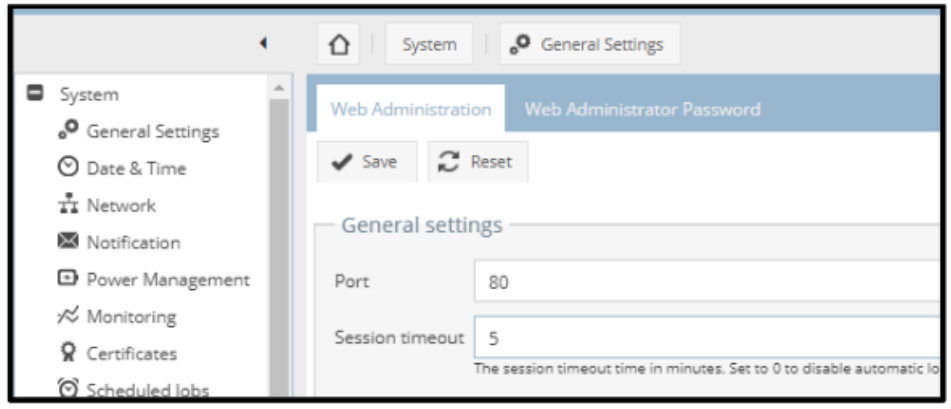

Gambar 4.16 Tampilan nilai awal pada perintah session timeout.

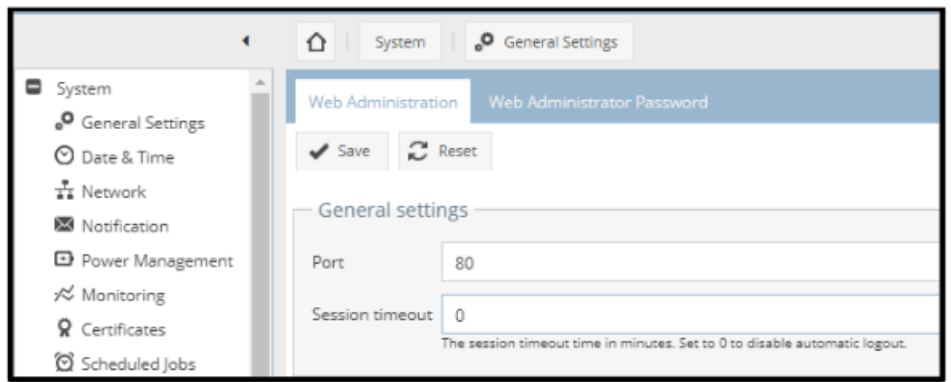

Gambar 4.17 Tampilan nilai sesudah diubah pada perintah session timeout.

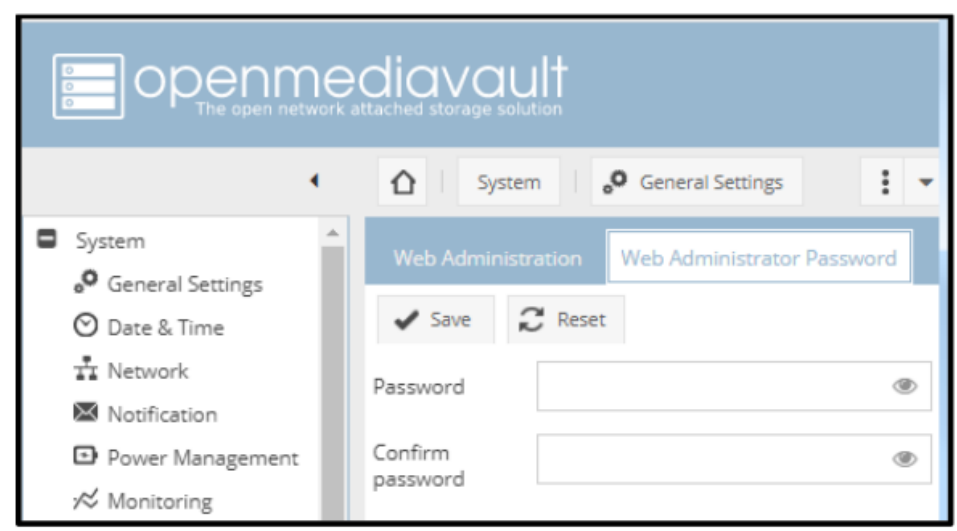

Gambar 4.18 Tampilan ubah password 
5. Langkah selanjutnya, kita lakukan konfigurasi menggunakan SSH, dalam hal ini mengunakan aplikasi pihak ketiga yaitu putty dengan terlebih dahulu mengaktifkan menu SSH. Dengan cara menu services pada panel sebelah kiri kemudian klik SSH. Ganti panel dari posisi off ke posisi on pada perintah "Permit root Login", setelah itu klik save, dan klik apply.

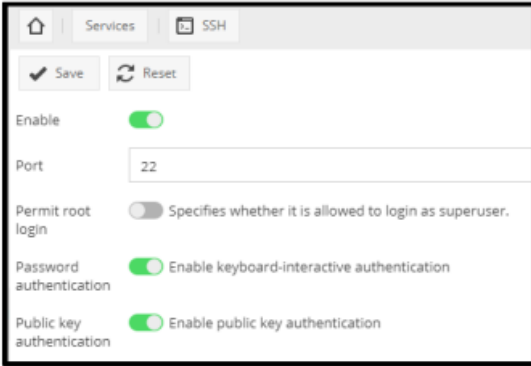

Gambar 4.19 Tampilan permit root masih pada posisi Off

$$
\begin{aligned}
& \checkmark \text { Sove } \approx \text { Reses } \\
& \text { Enable } \subset \\
& \text { Port } 22 \\
& \text { Permit root } \bigcirc \text { specties whether it is allowed to login as superuser. } \\
& \text { Password } C \text { Enable keyboard-interactive authentication } \\
& \text { Public key } \subseteq \text { Enable public key authentication }
\end{aligned}
$$

Gambar 4.20 Tampilan permit root sudah diposisi On

6. Langkah berikutnya kita mengakses menggunakan putty yang telah didownload. Sesuaikan konfigurasi dengan dibawah ini ;

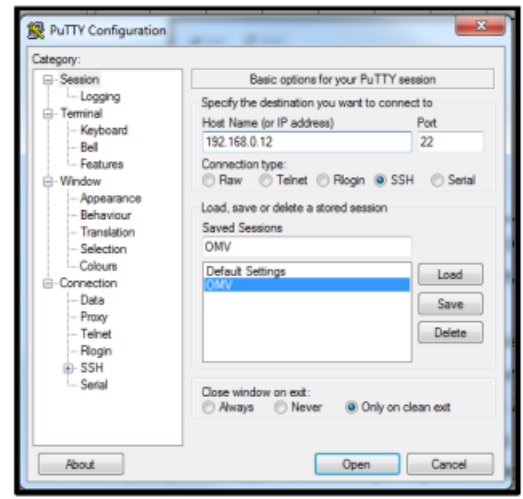

Gambar 4.21 Tampilan putty yang sudah disesuaikan dengan alamat IP 


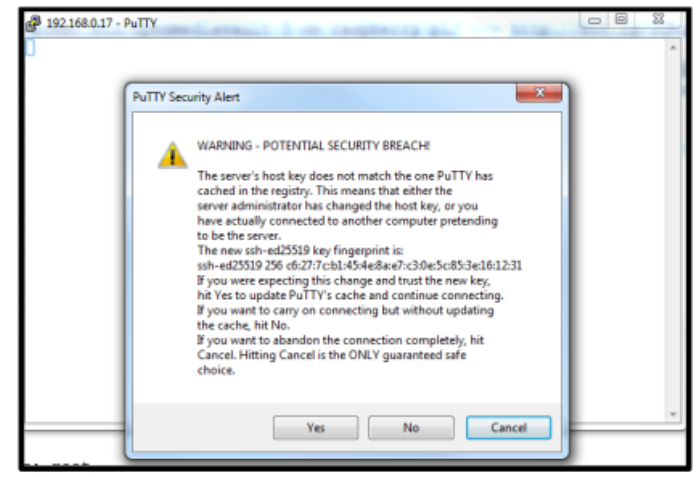

Gambar 4.22 Tampilan diatas siap untuk digunakan

7. Selanjutnya masuk sebagai posisi superuser dimana "superuser = root" dengan "password = openmediavault". Setelah berhasil, kita diperintahkan membuat password yang berbeda dengan password default

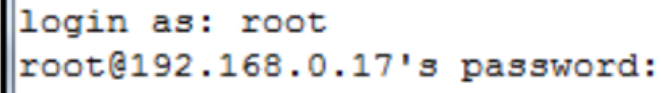

Gambar 4.23 Tampilan masuk sebagai superuser

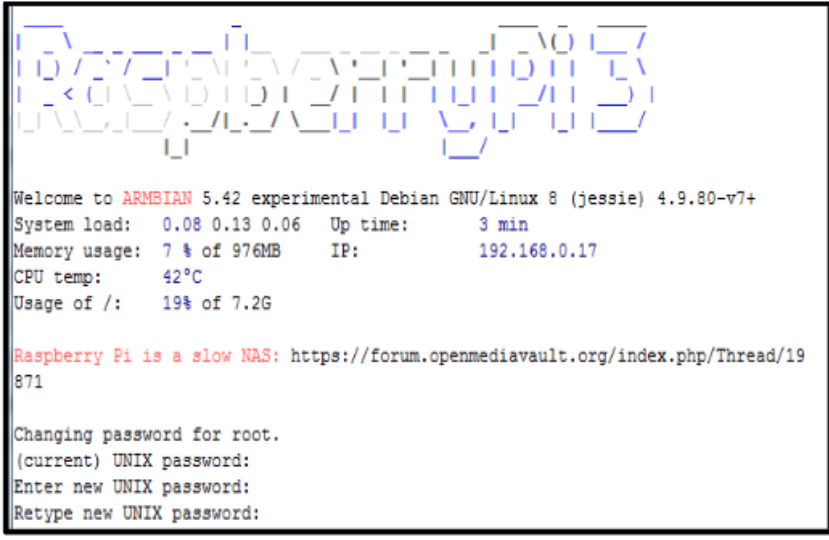

Gambar 4.24 Tampilan untuk perubahan password pada posisi superuser 
8. Selanjutnya, masukan perintah untuk update dan upgrade pada mode teminal yaitu “\# apt-get update" dan “\# apt-get upgrade”. Untuk lebih ringkas, kita bisa melakukan 2 perintah sekaligus “\# apt-get update ; apt-get upgrade”, atau bisa menggunakan “\# apt-get update --fix-missing; apt-get upgrade --fix -missing."

rooteraspi3bplus: \# apt-get update ; apt-get upgrade

root@raspi3bplus: \# apt-get update --fix-missing;apt-get upgrade --fix-missing

Gambar 4.25 Perintah untuk memperbaharui dan mengupgrade kernel pada sistem Open Media Vault.

9. Kemudian hapus file "99-default.link" pada lokasi "/etc/systemd/network/". Dengan memasukan perintah "rm -f"

: \# rm -f /etc/systemd/network/99-default.link

Gambar 4.26 Perintah menghapus file

10.Untuk perintah general berupa text yang mudah dapat menggunakan perintah "omv-firstaid", seperti langkah dibawah ini.

$$
\text { : \# omv-firstaid }
$$

Gambar 4.27 Perintah general berupa text

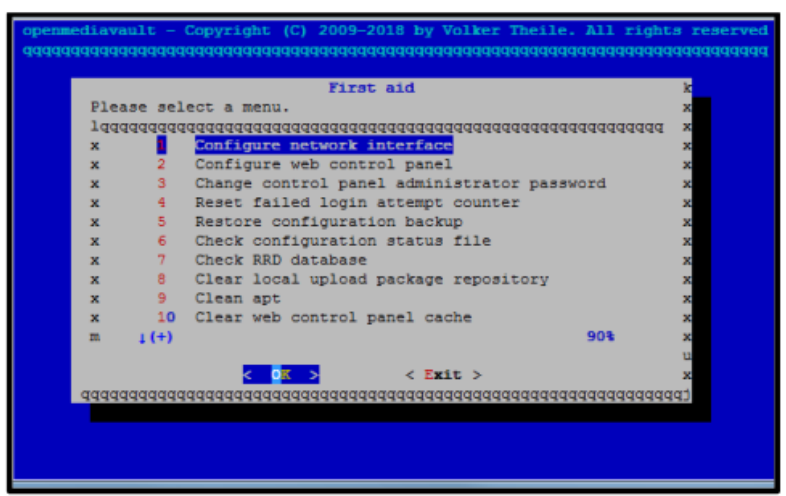

Gambar 4.28 Perintah general untuk mempermudah 
11. Sesudah itu reboot mesin Open Media Vault, bisa menggunakan perintah "\# reboot" atau mode GUI.

$$
\text { : } \sim \text { meboot }
$$

Gambar 4.29 Perintah melakukan reboot menggunakan terminal

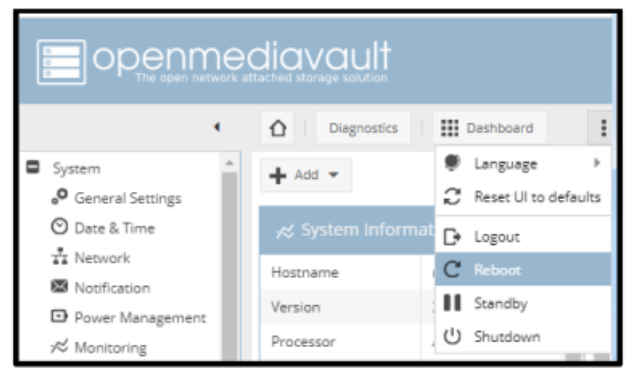

Gambar 4.30 Letak posisi reboot menggunakan interface

12. Setelah mesin raspberry kembali menyala, download dari situs Github.com berupa script bash dengan perintah dibawah ini "wget -O - https://github.com/OpenMediaVaultPlugin-

Developers/installScript/raw/master/install | sudo bash".

root@raspi3bplus: \# wget -0 - https://github.com/OpenMediaVault-Plugin-Developers/i hstallscript/raw/master/install | sudo bash |

Gambar 4.31 Perintah download dari source code Github.

13. Lalu, copy script pada file sources.list menggunakan perintah $\mathrm{cp}$ pada direktrori /etc/apt/ menjadi sources.list_backup.

\# cp /etc/apt/sources.list/etc/apt/sources.list_backup

Gambar 4.32 Perintah copy sources.list menjadi sources.list_backup 
14. Tambahkan script pada file sources.list menggunakan perintah nano pada direktrori /etc/apt/. Tambahkan script dibawah ini

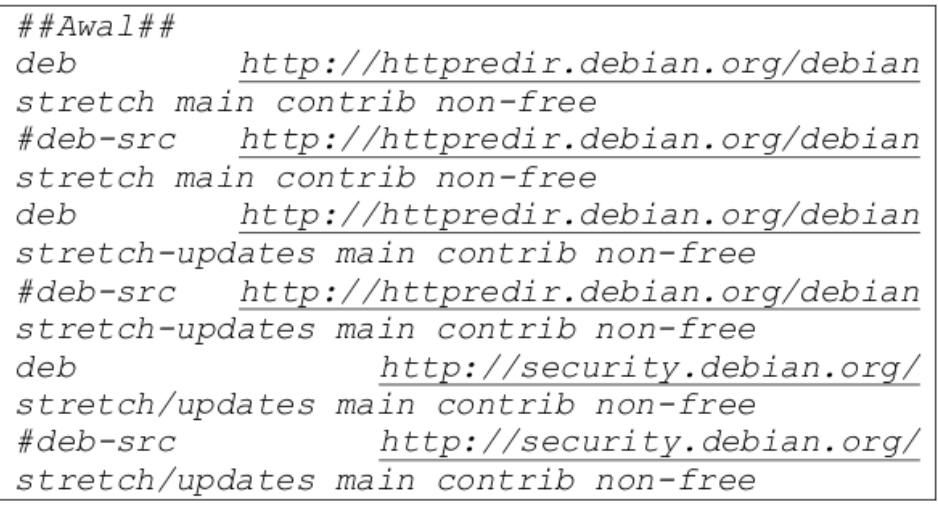

Gambar 4.33 Script awal sources.list pada direktori /etc/apt/.

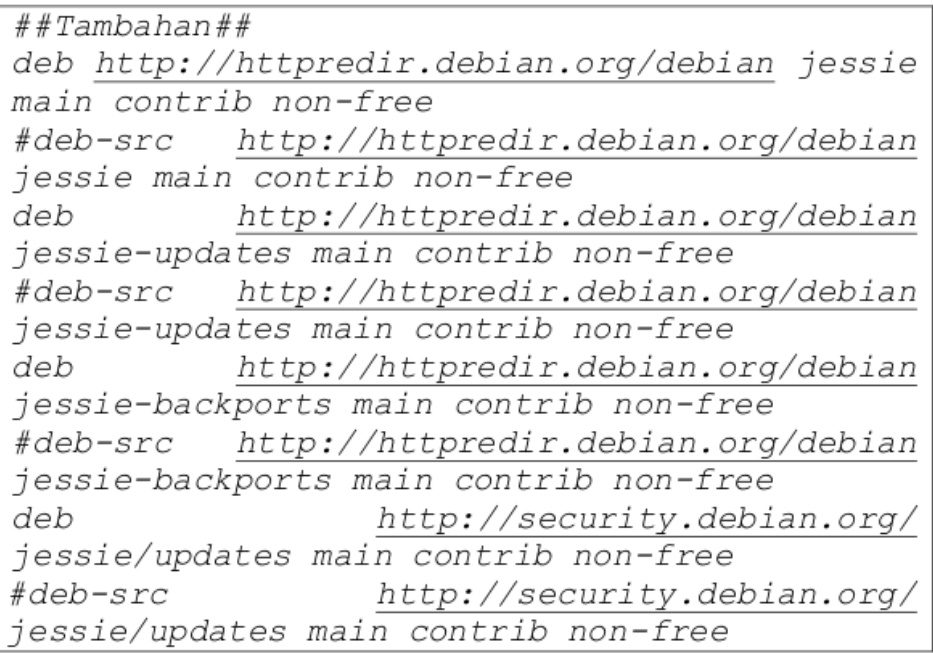

Gambar 4.34 Script tambahan setelah perintah diatas.

15. Selanjutnya, masukan perintah untuk update dan upgrade pada langkah sebelumnya yaitu pada No. 8 "\# apt-get update ; apt-get upgrade".

16. Langkah berikutnya, buat direktori dengan nama sh pada posisi home dengan perintah "mkdir sh". Kemudian masuk kedalam direktori "sh" dan selanjutnya buat file yaitu "satu.sh" dan 
"dua.sh", dengan perintah nano. Dimana file "satu.sh" dan "dua.sh", berisikan script yang seperti dibawah ini setelah selesai ctrl $+z$ dan ketikan :wq dimana perintah tersebut write dan dan quit.

$$
\sim \text { mkdir } \mathrm{sh}
$$

Gambar 4.35 Perintah membuat direktori

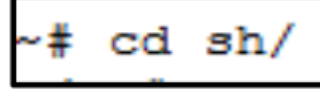

Gambar 4.36 Perintah masuk kedalam direktori

$$
: \sim / \operatorname{sh} \# \text { nano satu.sh }
$$

Gambar 4.37 Perintah membuat isi script file satu. sh

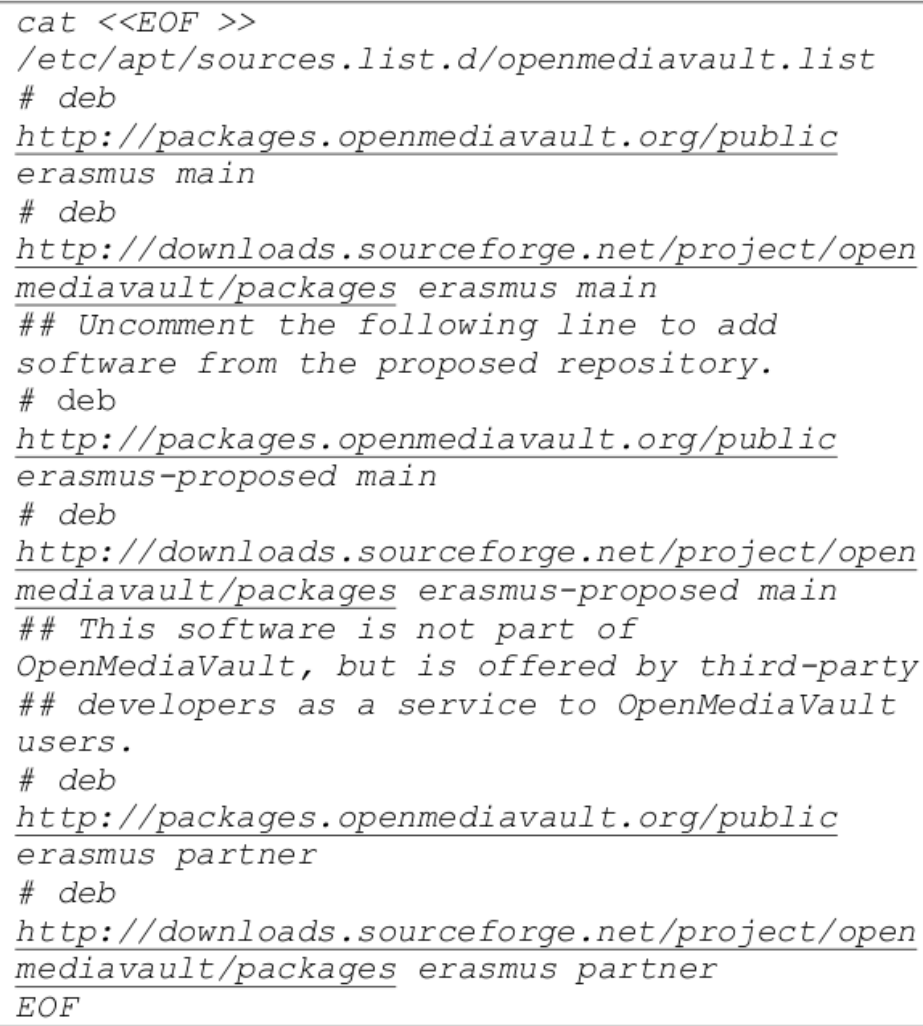

Gambar 4.38 Perintah isi script pada file satu. sh 


\section{$\sim / \mathrm{sh} \#$ nano dua.sh}

Gambar 4.39 Perintah membuat isi script file dua.sh

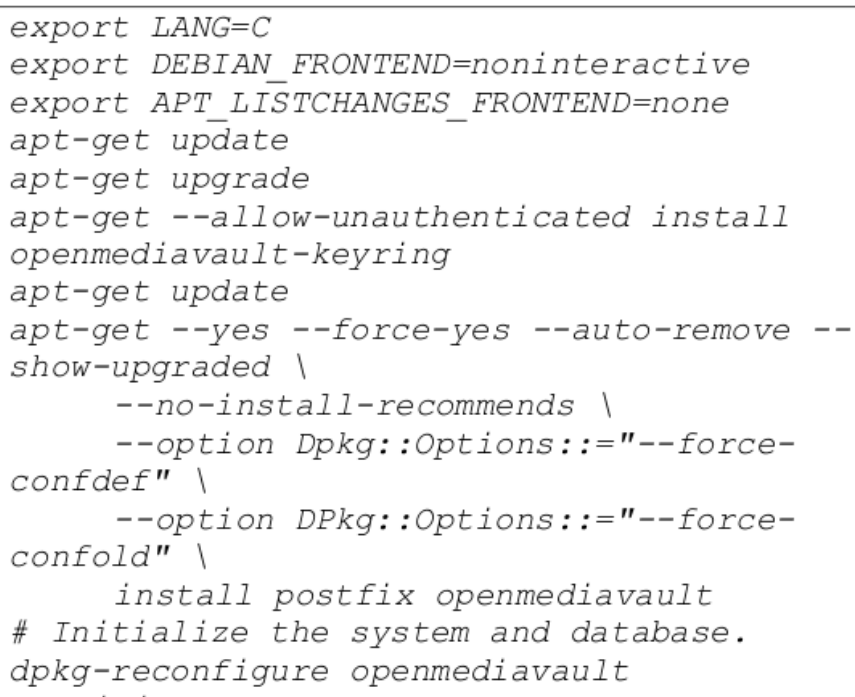

Gambar 4.40 Perintah script pada file dua . sh

17. Sebelumnya melakukan perintah eksekusi ke script, lakukan perintah ini terlebih dahulu ke dua file yaitu "satu.sh" dan "dua.sh", dengan melakukan perintah "chmod $+\mathrm{x}$ satu.sh" dan "chmod $+\mathrm{x}$ dua.sh" atau mengunakan satu perintah sekaligus "chmod $+x$ satu.sh ; chmod $+x$ dua.sh".

: $\sim / \operatorname{sh} \#$ chmod $+\mathrm{x}$ satu.sh ; chmod $+\mathrm{x}$ dua.sh

Gambar 4.41 Perintah eksekusi dalam satu kali perintah

18. Langkah selanjutnya kita dapat mengeksekusi dua file diatas dengan menggunakan perintah instal script "sudo./satu.sh" dan "sudo ./satu.sh" atau satu perintah langsung "./satu.sh ; ./dua.sh" tanpa menngunakan sudo. Seperti perintah dibawah ini;

: $\sim / \operatorname{sh} \#$./satu.sh ; ./dua.sh

Gambar 4.42 Perintah melakukan eksekusi secara bersamaan 
19. Selanjutnya, lakukan proses reboot pada langkah sebelumnya yaitu pada No.10.

20. Setelah proses reboot selesai, login melalui webbrowser kita cek versi terbaru Open Media Vault pada system information.

\begin{tabular}{|l|l|}
\hline $\begin{array}{l}\text { Version } \\
\text { Processor }\end{array}$ & ARMv7 Processor rev 4(v7l) \\
\hline Kernel & Linux 4.9.80-v7+ \\
System time & Wed 23 Dec 2020 09:19:00 PM WIB \\
Uptime & 0 days 0 hours 22 minutes 38 seconds \\
Load average & $1.23,0.77,0.42$ \\
\hline
\end{tabular}

Gambar 4.43 Proses pembaruan versi 3.0.100 telah selesai.

\subsubsection{Konfigurasi S.M.A.R.T (Specific, Measurable, Achievable,} Relevant dan Timebound).

Proses pertama Open Media Vault pada Raspberry Pi $3 b+$, melakukan konfigurasi SMART (Specific, Measurable, Achievable, Relevant dan Timebound). Tujuan dilakukan agar kita dapat melihat redudansi pada media yang kita sediakan. langkah-langkah sebagai berikut ;

1. Buka browser dengan alamat sesuai yaitu "192.168.1.45" dengan password yang sudah tertera pada langkah sebelumnya dimana "user = admin" dengan "passw ord = openmediavault".

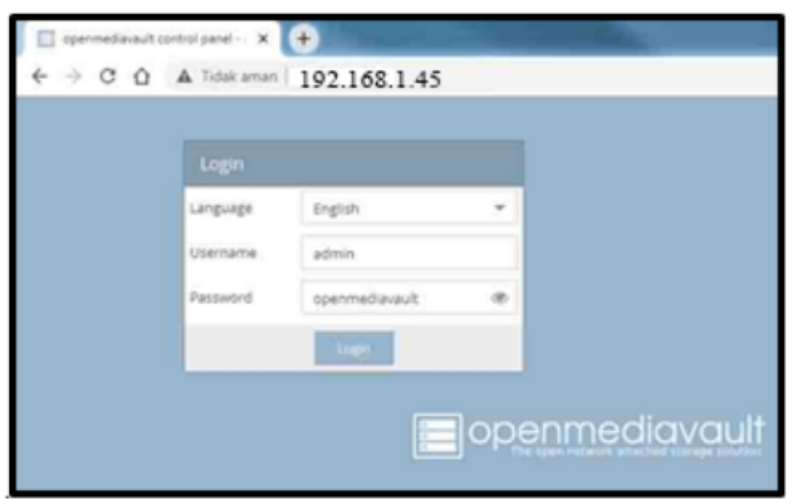

Gambar 4.44 Login dengan webbrowser 
2. Pilih "Storage" klik "SMART" ganti posisi "Disable" ke

"Enable" kemudian klik "Save" dan klik "Apply"

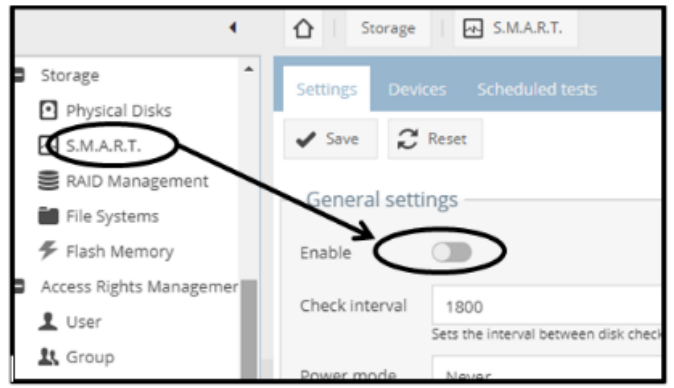

Gambar 4.45 Proses aktifasi SMART

3. Pilih salah satu "Storage" klik "Edit" ganti posisi "Disable" ke

"Enable" kemudian klik "Save" dan klik "Apply"

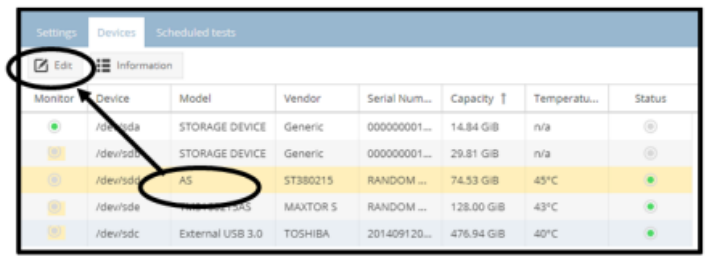

Gambar 4.46 Pilih salah satu drive dan klik edit.

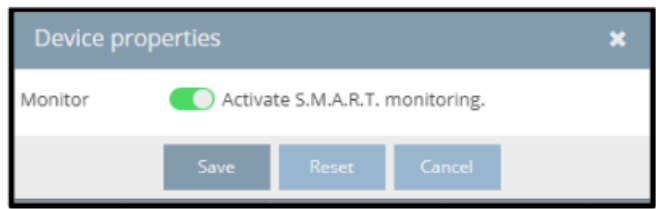

Gambar 4.47 Aktifasi monitoring SMART.

4. Hasil dari semua Monitoring Smart sudah di aktifasi di semua media penyimpanan yang ada

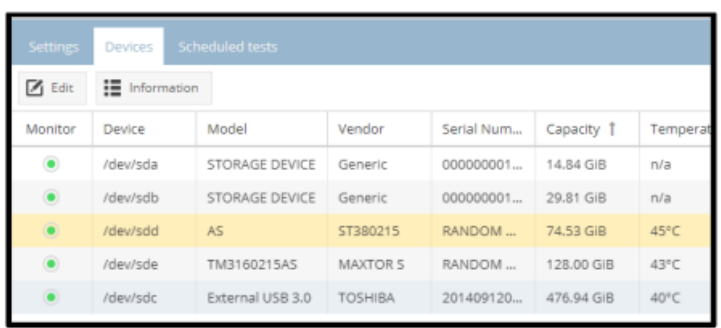

Gambar 4.48 Proses aktifasi SMART pada semua media 


\subsubsection{Konfigurasi Media Penyimpanan di OMV (Open Media Vault),}

serta Konfigurasi Desain and Creation pada Raspberry $\mathbf{P i}$

Proses awal mula Open Media Vault pada Raspberry Pi 3b+, dapat dilakukan sebagaimana langkah-langkah sebagai berikut ;

1. Sebelum terpasang, pastikan tidak ada device yang tertancap. Jika kita liat bisa dilihat pada menu "Storage, Physical Disks" dan hanya ada satu device yang tertancap yaitu Micro SD berupa Operating Sistem Open Media Vault.

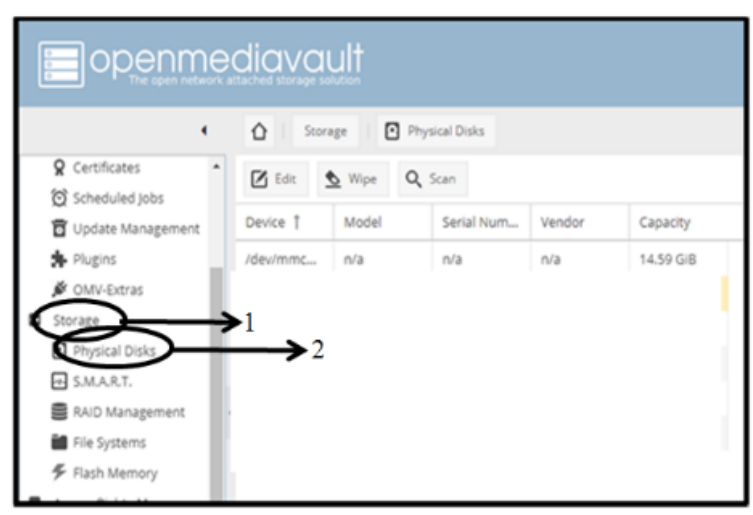

Gambar 4.49 Device belum terpasang pada perangkat Raspberry Pi 3b+

2. Kemudian Pasang semua jenis harddisk baik SSD, HDD atau Mikro SD. Setelah terpasang, klik tombol "Scan" pada menu samping bar yaitu "Storage, Physical Disks", maka akan tampil device seperti gambar dibawah ini

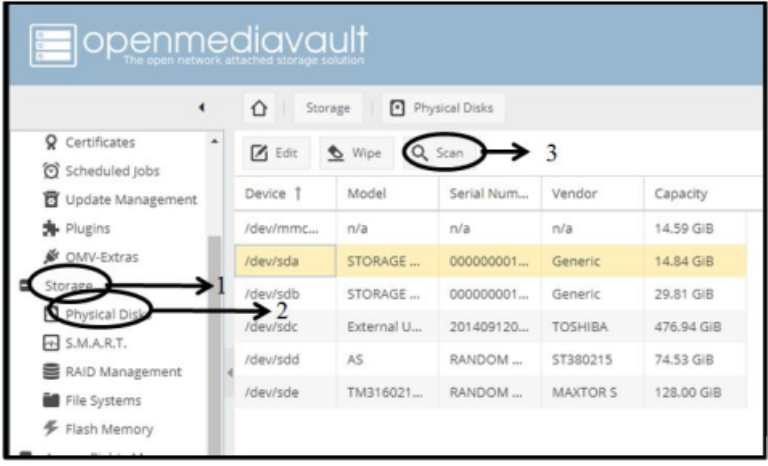

Gambar 4.50 Device yang terpasang sudah muncul pada perangkat Raspberry $\mathrm{Pi} 3 \mathrm{~b}+$ 
3. Setelah terpasang hapus semua data yang terdapat pada semua device baik HDD, SSD, dan mikro SD dengan cara pilih media storage klik "Wipe" pada "Storage, Physical Disks".

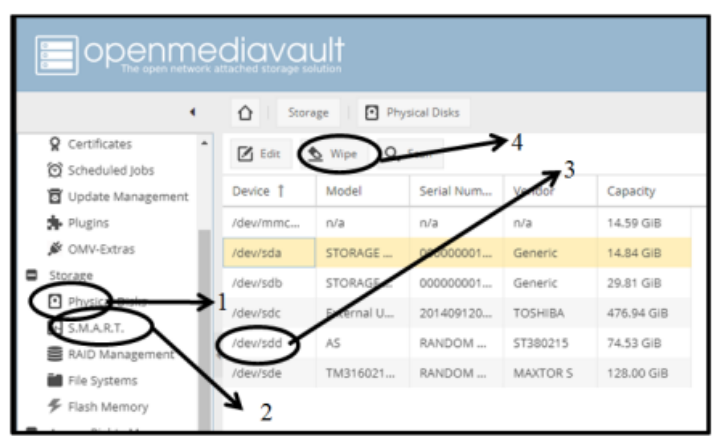

Gambar 4.51 Proses penghapusan data pada semua device yang terpasang

4. Pada proses "Wipe" akan muncul notifikasi bahwa device yang terpilih diatas akan dihapus dan lakukan tahapan diatas pada semua device yang ada. Seperti gambar dibawah ini ;

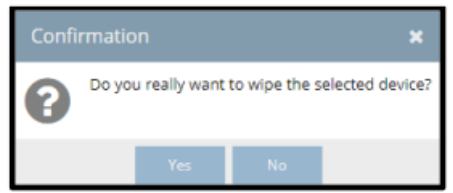

Gambar 4.52 Notifikasi konfirmasi device akan dihapus

\section{Wiping device. .}

?

Please choose the method to wipe the device or 'Cancel' to abort'

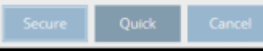

Gambar 4.53 Pilih metode untuk menghapus device

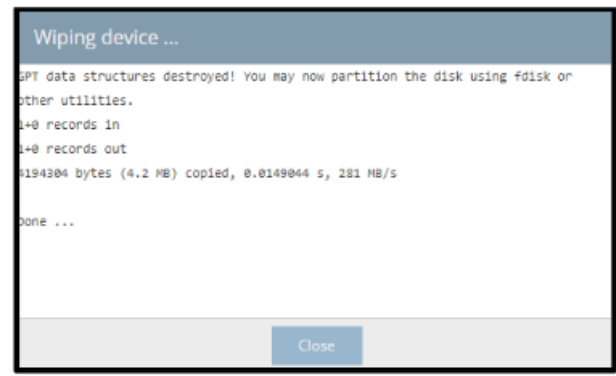

Gambar 4.54 Proses wiping divice sedang berlangsung 
5. Untuk manajemen HDD, SSD dan Micro SD menggunakan manajemen "RAID 5", dengan ketersediaan 2 jenis HDD jenis docking, 2 Micro SD, dan satu jenis SSD.

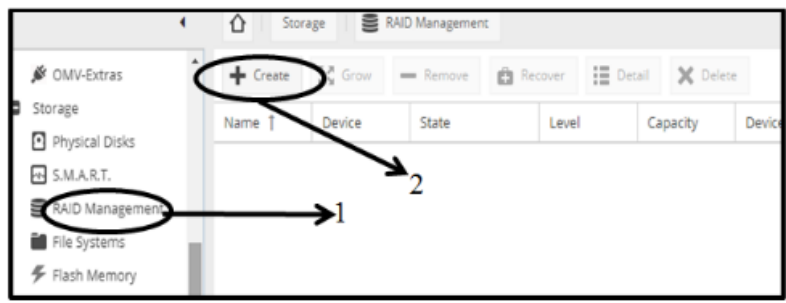

Gambar 4.55 Proses pembuatan RAID

6. Selanjutnya untuk membuat metode RAID 5 akan tampil seperti dibawah ini ;

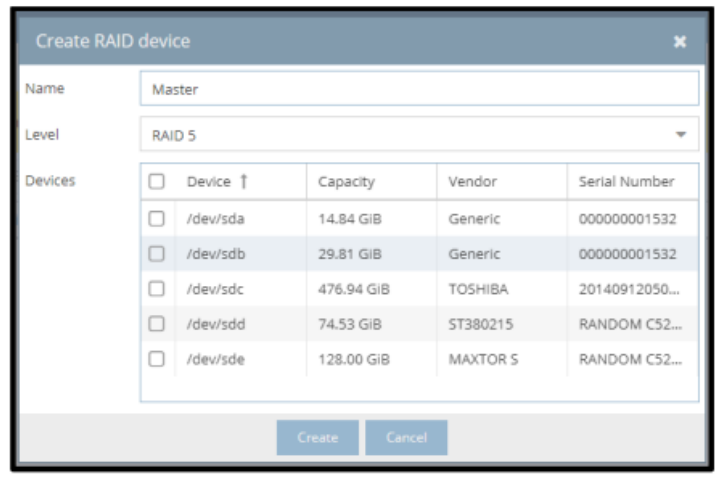

Gambar 4.56 Proses pemilihan Harddisk

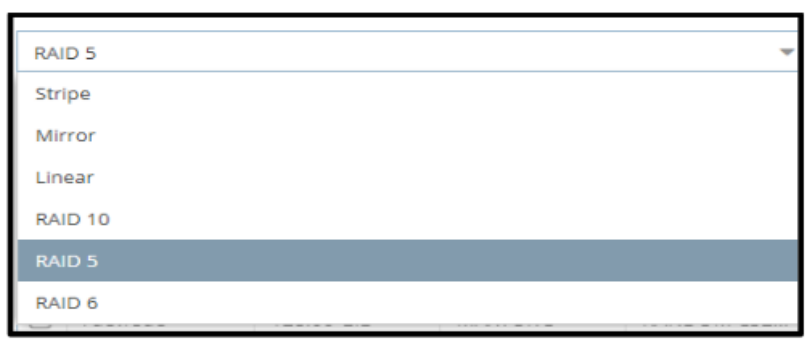

Gambar 4.57 Pemilihan jenis Raid yaitu RAID 5 


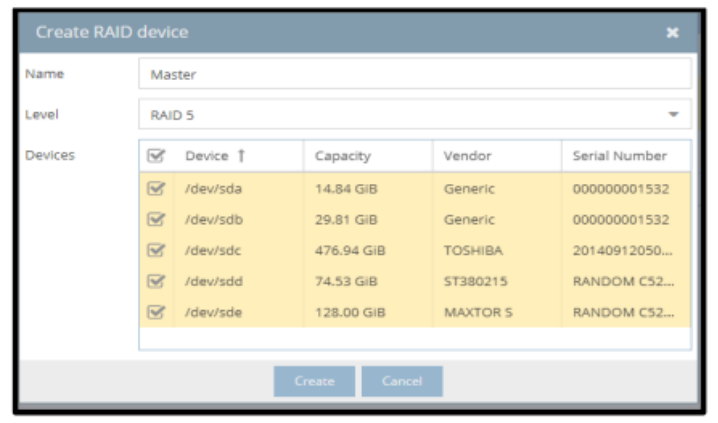

Gambar 4.58 Pilih semua drive untuk pengunaan RAID 5

\begin{tabular}{|l|c|c|c|}
\hline \multicolumn{1}{|c|}{ Device } & Model & Jenis & Kapasitas \\
\hline$/ \mathrm{dev} / \mathrm{mmcb} l \mathrm{ko}$ & $\mathrm{n} / \mathrm{a}$ & Micro SD & $16 \mathrm{~Gb}$ \\
\hline$/ \mathrm{dev} / \mathrm{sda}$ & Storage device & Micro SD & $32 \mathrm{gb}$ \\
\hline$/ \mathrm{dev} / \mathrm{sdb}$ & Storage device & Micro SD & $16 \mathrm{~Gb}$ \\
\hline$/ \mathrm{dev} / \mathrm{sdc}$ & Ext usb 3.0 & $\mathrm{SSD}$ & $500 \mathrm{~Gb}$ \\
\hline$/ \mathrm{dev} / \mathrm{sdd}$ & $\mathrm{AS}$ & $\mathrm{HDD}$ & $80 \mathrm{~Gb}$ \\
\hline$/ \mathrm{dev} / \mathrm{sde}$ & $\mathrm{TM} 3160215 \mathrm{AS}$ & $\mathrm{HDD}$ & $160 \mathrm{~Gb}$ \\
\hline
\end{tabular}

Tabel 4.59 Pilih aneka jenis drive dengan tujuan tercipta desain and creation

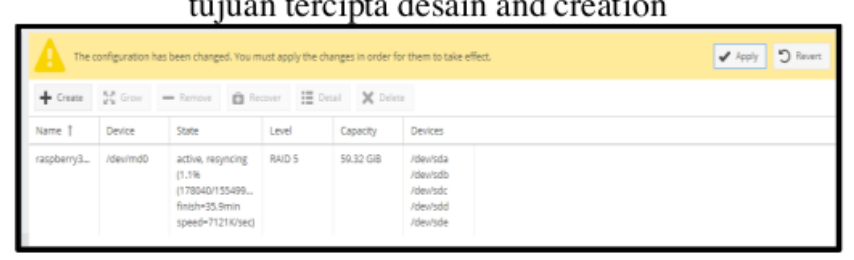

Gambar 4.60 Proses RAID 5 selesai dan klik Apply

7. Proses selanjutnya berupa drive yang akan di shared folder tahapanya sebagai berikut

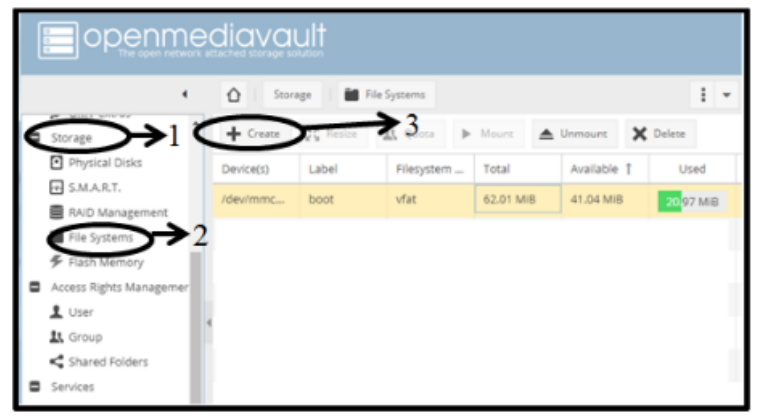

Gambar 4.61 Proses mounting device 
Setelah klik menu "Create", maka akan tampil intruksi device mana yang akan dibuat menjadi "File System" dan klik "Ok" seperti tampilan dibawah ini

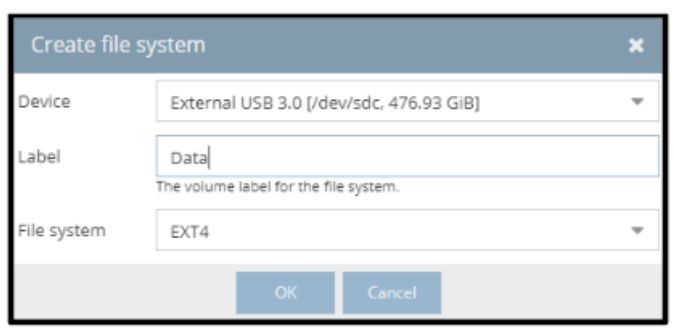

Gambar 4.62 Proses create file system dengan memilih device dan jenis file system yang digunakan

Selanjutnya akan muncul pemberitahuan bahwa data akan dihapus.

Seperti tampilan dibawah ini,

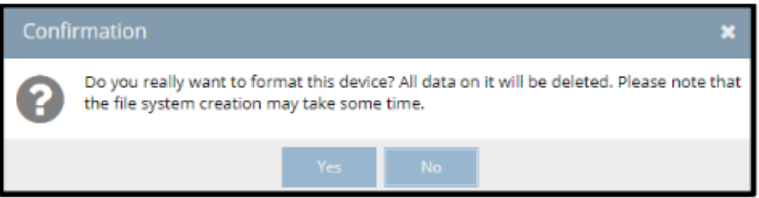

Gambar 4.63 Notifikasi konfirmasi device akan dihapus

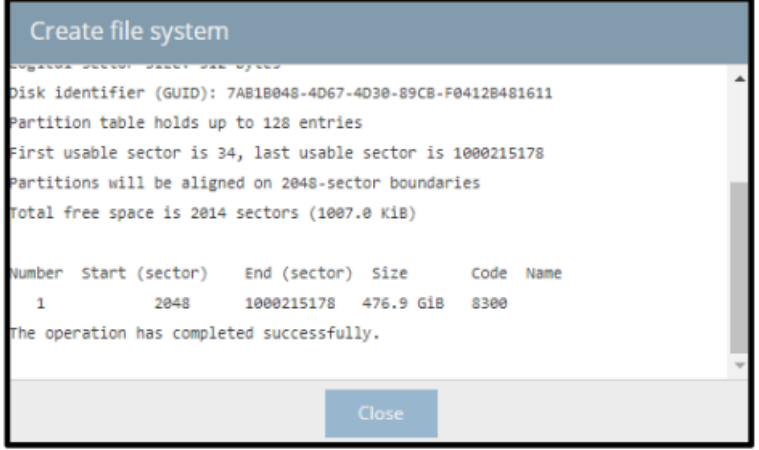

Gambar 4.64 Proses create file system sedang berlangsung

Setelah proses diatas selesai, mounting device dengan klik menu

"Mount", dan klik Apply untuk merestart layanan yang "Mount". Seperti tampilan dibawah ini, 


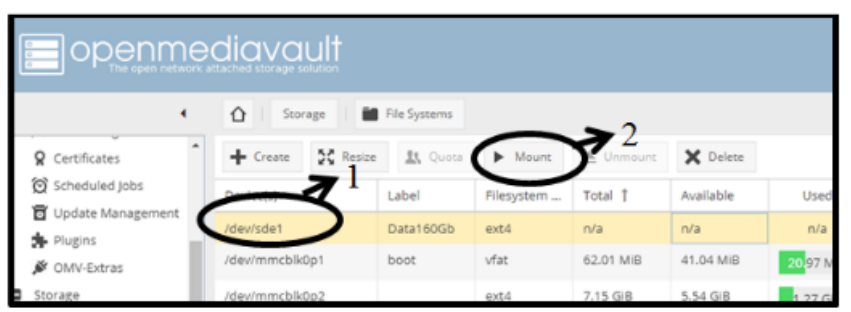

Gambar 4.65 Proses mounting harddisk RAID

The configuration has been changed. You must apply the changes in order for them to take effect. $\checkmark$ Apply $\checkmark$ Revert

Gambar 4.66 Tampilan notifikasi untuk pembaruan konfigurasi

\subsubsection{Konfigurasi User Account di OMV (Open Media Vault)}

Langkah selanjutnya, ialah membuat user account untuk mengakses Open Media Vault pada Raspberry Pi 3b+, dapat dilakukan sebagaimana langkah-langkah sebagai berikut ;

1. Klik "Access Right Management", arahkan ke "Users" lanjut ke arah "Add". Seperti gambar dibawah ini ;

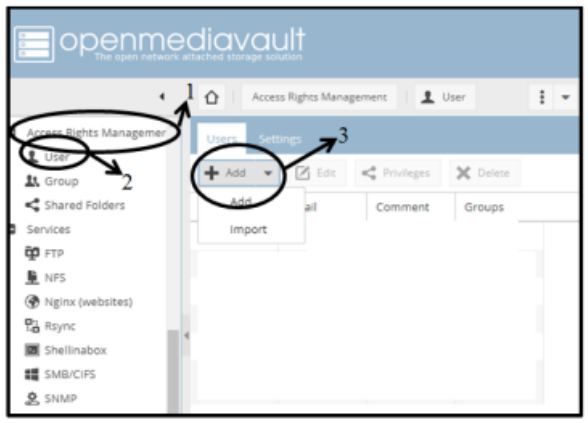

Gambar 4.67 Tampilan konfigurasi pembuatan user account untuk Open Media Vault 
2. Lanjut untuk pengisian biodata yang diperlukan seperti gambar dibawah ini ;

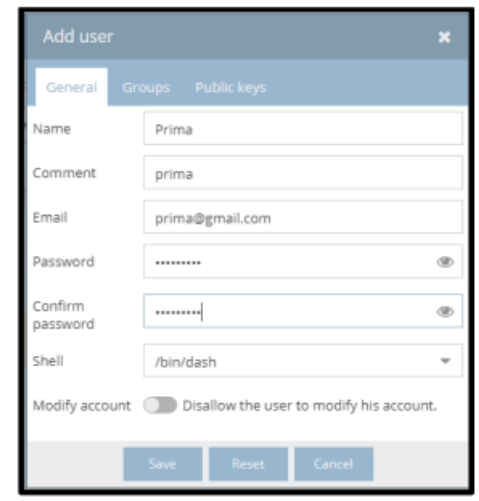

Gambar 4.68 Tampilan form akun

3. Isi dan buat sesuai dengan kebutuhan yang diperlukan, seperti menjadi tampilan dibawah ini ;

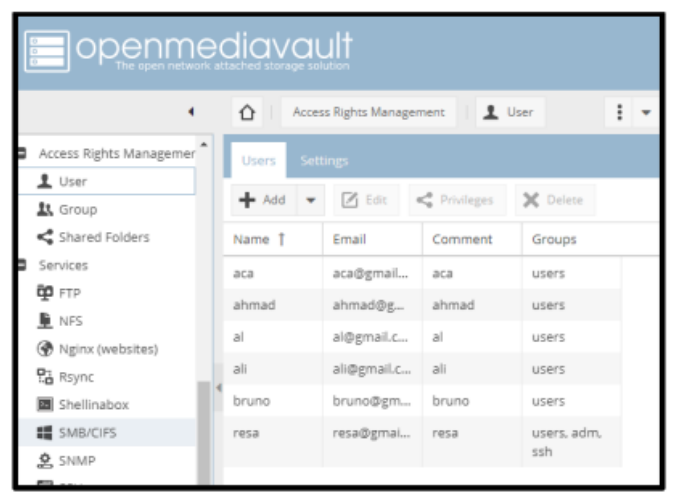

Gambar 4.69 Tampilan akun sesuai dengan kebutuhan

\begin{tabular}{|l|c|c|c|}
\hline \multicolumn{1}{|c|}{ User } & Email & Pass & Confrim Pass \\
\hline aca & aca@gmail.com & aca1234 & aca1234 \\
\hline ahmad & ahmad@gmail.com & ahmad1234 & ahmad1234 \\
\hline al & al@gmail.com & al1234 & al1234 \\
\hline ali & ali@gmail.com & ali1234 & ali1234 \\
\hline bruno & bruno@gmail.com & bruno1234 & bruno1234 \\
\hline resa & resa@gmail.com & resa1234 & resa1234 \\
\hline
\end{tabular}

Tabel 4.70 Tabel akun dan password sesuai dengan kebutuhan 


\subsubsection{Konfigurasi Shared Folder di OMV (Open Media Vault).}

Setelah langkah diatas, langkah selanjutnya ialah konfigurasi shared folder pada Open Media Vault di Raspberry Pi 3b+, dapat dilakukan sebagaimana langkah-langkah sebagai berikut ;

1. Klik "Access Right Management", arahkan ke "Users" lanjut ke arah "Add". Seperti gambar dibawah ini ;

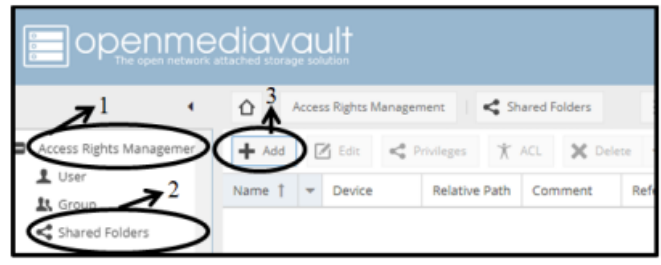

Gambar 4.71 Tahapan konfigurasi shared folder

2. Isi form dengan ketentuan "Name", pilih "Drive" dengan keinginan, pilih "Path" dam pilih ketentuan berupa "Everyone". Seperti gambar dibawah ini ;

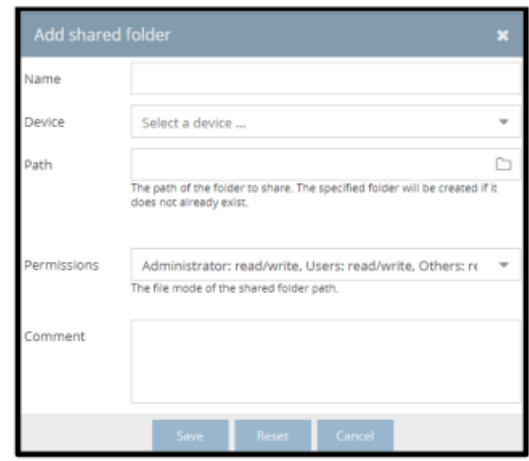

Gambar 4.72 Tampilan konfigurasi shared folder

3. Pilih drive yang ada berupa Drive dengan RAID Management seperti gambar dibawah ini ;

RAID [51.83 MiB (1\%) used, 58.16 GiB available]

RAID [51.83 MiB (196) used, 58.16 GiB available]

Gambar 4.73 Tampilan device yang muncul hanya muncul satu karena sudah diubah menjadi RAID 5. 
4. Pilih directory yang sesuai dengan kebutuhan, seperti gambar dibawah ini ;

\begin{tabular}{l}
\hline Select a directory \\
$\mathbf{x} \square$ lost+found \\
\hline
\end{tabular}

Gambar 4.74 Tampilan konfigurasi shared folder

5. Sehingga menjadi konfigurasi seperti bawah dengan hak izin Permissions everyone Read/Write, seperti gambar dibawah ini ;

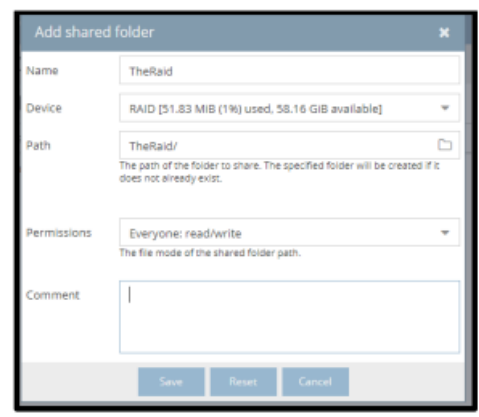

Gambar 4.75 Tampilan akhir konfigurasi shared folder

6. Tahapan selanjutnya, ialah pengaturan privilage untuk mengatur bagian direktori/folder sesuai kebutuhan, untuk dibagian ini semua akun di create dengan status Read/Write. Untuk cara pengaturanya seperti gambar dibawah ini ;

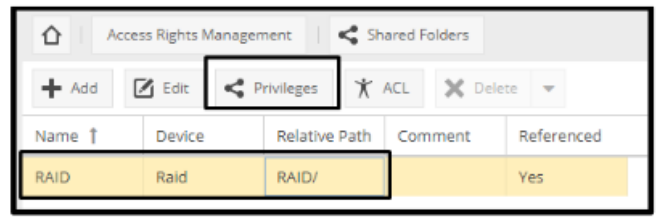

Gambar 4.76 Pilih drive kemudian klik privilage

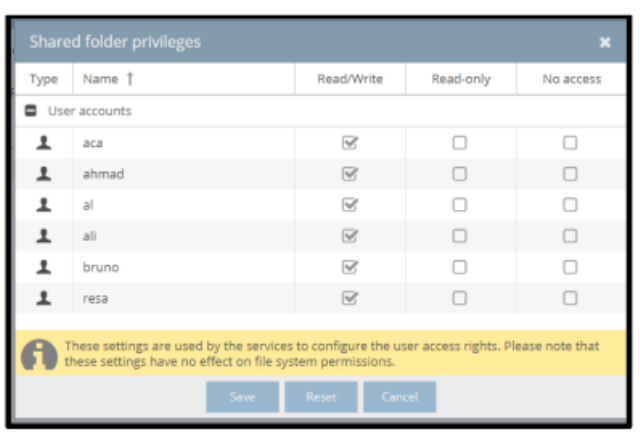

Gambar 4.77 Ubah posisi semua user menjadi status Read/Write 
7. selanjutnya, bukan aplikasi WinSCP. Buat create Login dengan ketentuan IP 192.168.1.45 dengan port 321 dengan ketentuan pada Tabel 4.70 Tabel akun dan password,

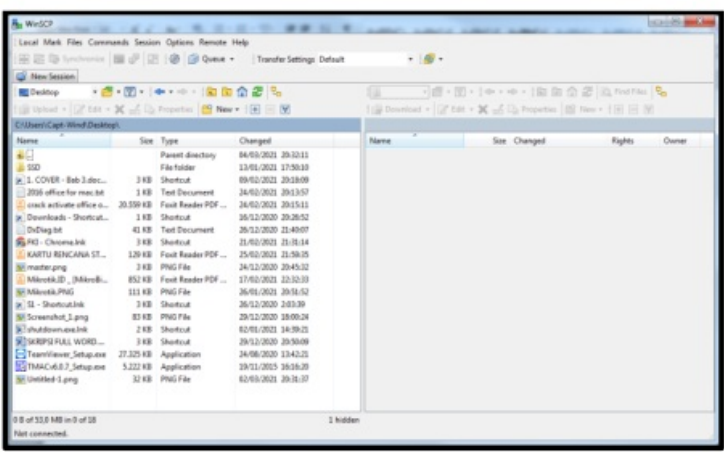

Gambar 4.78 Tampilan Aplikasi WinScp

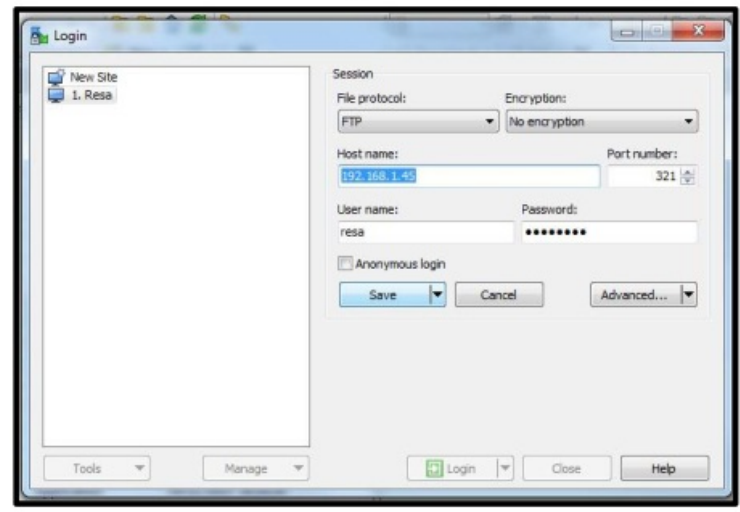

Gambar 4.79 Tampilan configurasi WinSCP untuk login

8. Maka tampil folder paling atas berupa "RAID", langkah selanjutnya buat 3 folder antara lain "Grup 1, Grup 2, Grup 3", untuk lebih detailnya seperti gambar dibawah ini ;

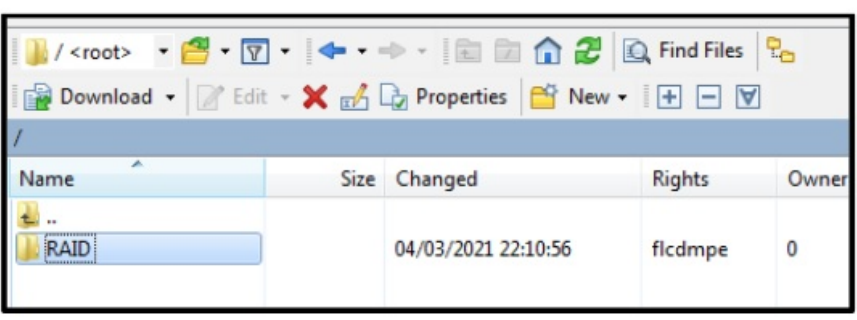

Gambar 4.80 Tampilan folder teratas berupa folder RAID. 


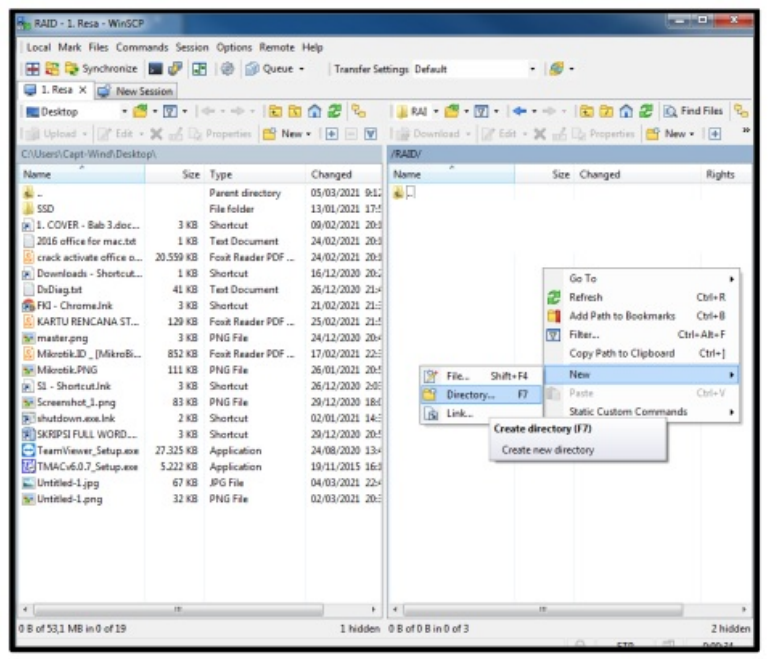

Gambar 4.81 Tampilan pembuatan folder Grup 1 hingga Grup 3

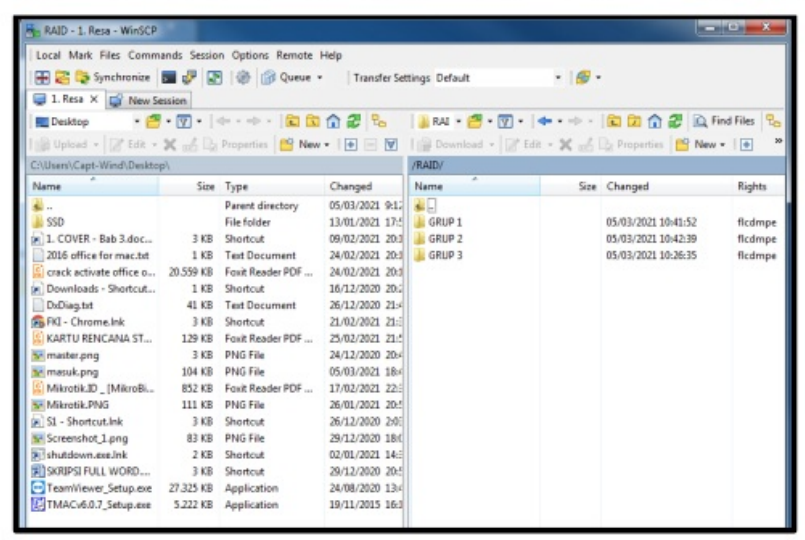

Gambar 4.82 Tampilan sesudah membuat Folder Grup 1 hingga Grup 3

9. Tidak sampai diatas, langkah berikutnya adalah memodifikasi ACL (Access Control List) yang hanya ditemukan di Open Media Vault, dimana 3 folder antara lain "Grup 1, Grup 2, Grup 3", untuk lebih detailnya seperti gambar dibawah ini ;

\begin{tabular}{|c|c|c|c|c|c|}
\hline + Add & 4 Edit & $<$ Privileges & $\pi$ & $x$ & $\checkmark$ \\
\hline Name $\uparrow$ & Device & Relative & Path & Comment & Referenced \\
\hline RAID & Raid & RAID/ & & & Yes \\
\hline
\end{tabular}

Gambar 4.83 Pilih drive kemudian pilih ACL 


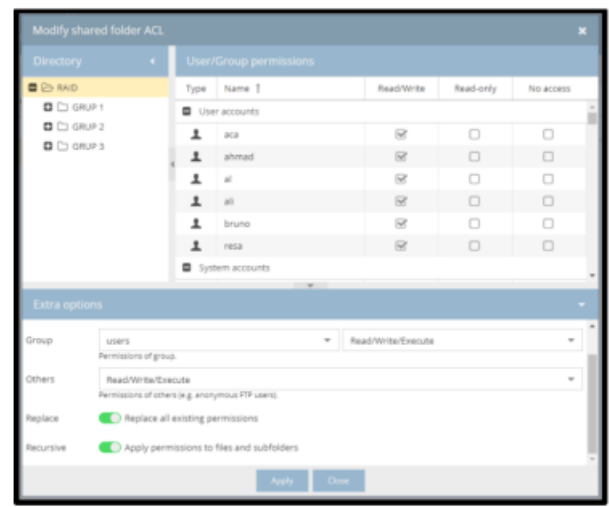

Gambar 4.84 Untuk folder paling atas berupa Raid, konfigurasi dengan mode Read/Write

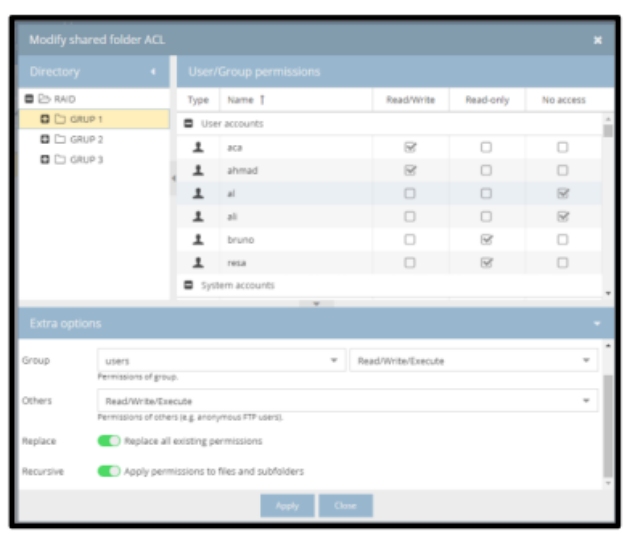

Gambar 4.85 Untuk folder Grup 1

dikonfigurasikan sesuai kebutuhan

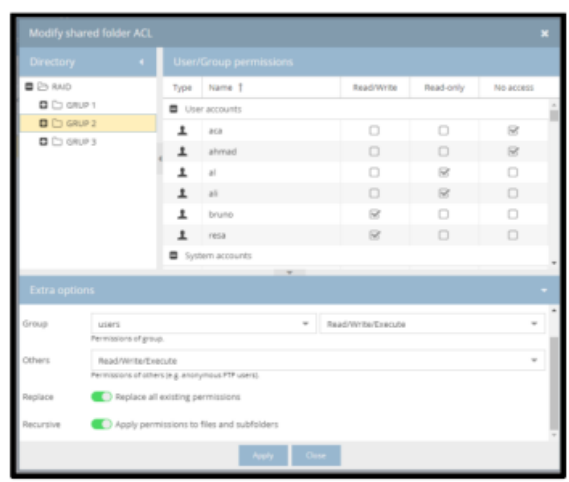

Gambar 4.86 Untuk folder Grup 2

dikonfigurasikan sesuai kebutuhan 


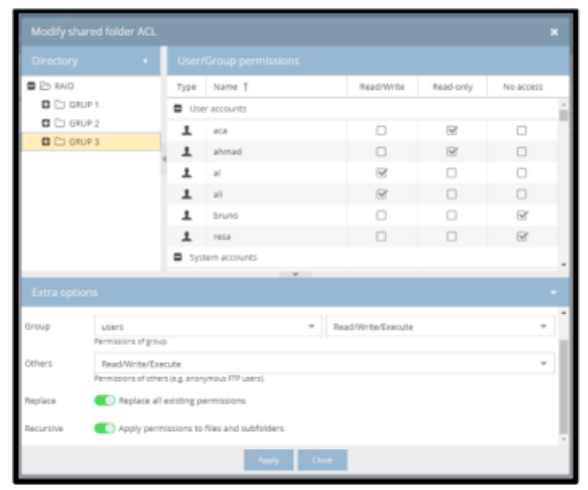

Gambar 4.87 Untuk folder Grup 3 dikonfigurasikan sesuai kebutuhan

10. Untuk lebih mudah membacanya, memodifikasi ACL (Access Control List) diatas diubah menjadi bentuk tabel dari pengguna hingga Folder berupa Grup 1, Grup 2, Grup 3, untuk lebih jelasnya seperti tabel dibawah ini ;

\begin{tabular}{|l|c|c|c|}
\hline \multicolumn{1}{|c|}{ Name } & Grup 1 & Grup 2 & Grup 3 \\
\hline aca & V & X & O \\
\hline ahmad & V & X & O \\
\hline al & X & O & V \\
\hline ali & X & O & V \\
\hline bruno & O & V & X \\
\hline resa & O & V & X \\
\hline
\end{tabular}

Keterangan ;

$\mathrm{V}=$ Read $/$ Write $\mathrm{X}=$ No Akses $\mathrm{O}=$ Read Only

Tabel 4.88 Tabel akses user/grup akses

\subsubsection{Aktifasi FTP (File Transfer Protokol) di OMV (Open Media Vault)}

Langkah terakhir ialah mengaktifkan Protokol FTP, langkahlangkahnya sebagai berikut;

1. Pilih "Service" kemudian pilih "FTP", ganti ke posisi menjadi "Enable", ganti port default dari “21” ke port “321”, ubah max “connection per hosta” menjadi "0". Kurang lebih gambar seperti dibawah ini ; 


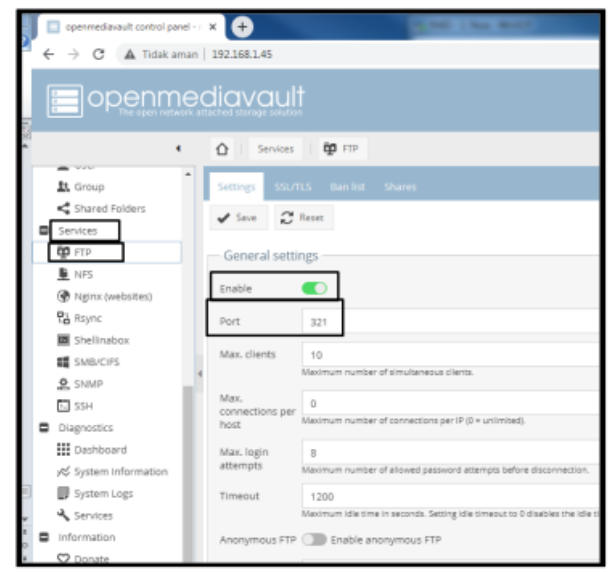

Gambar 4.89 Konfigurasi FTP pada OMV

2. Ganti ke tab sebelah yaitu "Share" dan Klik "Add". Ganti enable menjadi posisi on dan pastikan folder shared hanya pada harddisk RAID, seperti potongan gambar dibawah ini ;

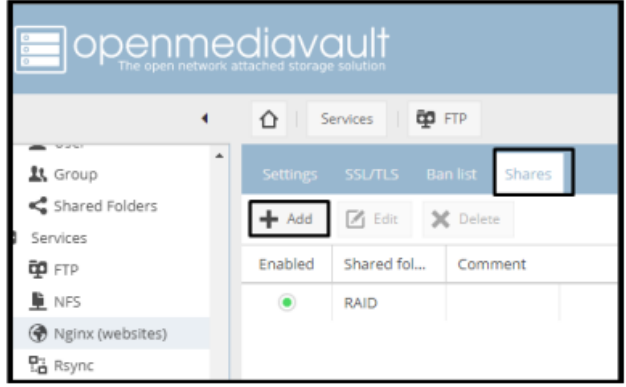

Gambar 4.90 Bagian yang akan dishare

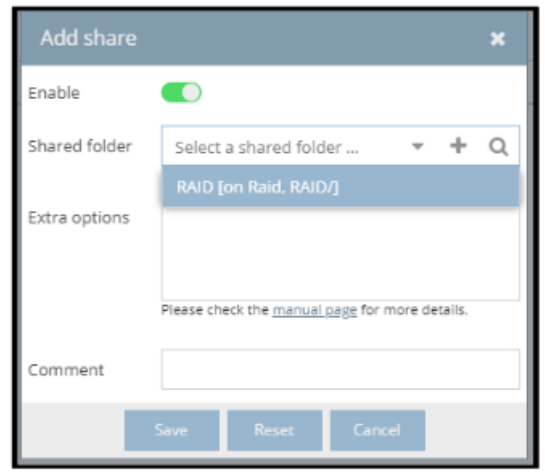

Gambar 4.91 Pilih drive yang tersedia 


\subsubsection{Proses Ujicoba FTP pada Jaringan Intranet}

Step terakhir ialah ujicoba Protokol FTP, untuk pertama proses testing kita ujicoba di platform Windows 7 dengan mengunakan aplikasi WinSCP, langkah-langkahnya sebagai berikut;

1. Pertama buat user dan login sesuai tabel sebelumnya, kemudian ganti port default dari "21" ke port “321", Kurang lebih penjelasnya seperti dibawah ini ;

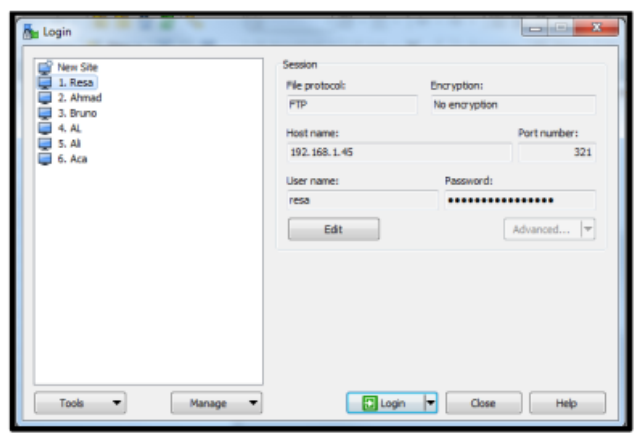

Gambar 4.92 Pembuatan user, login dan port pada WinSCP

2. Untuk uji coba pertama, untuk login saya menggunakan user : resa dengan password : resa1234. Untuk user : resa, pada folder Group 1, user : resa hanya bisa melihat apa saja yang ada di direktori, di folder Group 2 bisa menulis dan membaca file dan folder Group 3 tidak bisa diakses, penjelasnya bisa dilihat seperti gambar dibawah ini ;

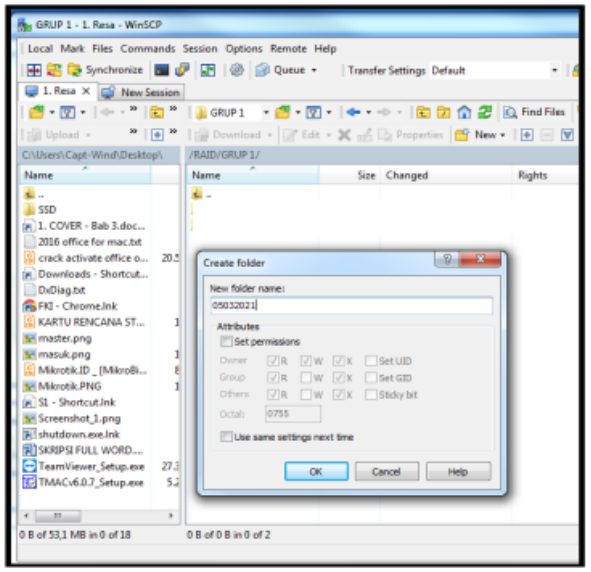

Gambar 4.93 Pembuatan folder pada Grup 1 


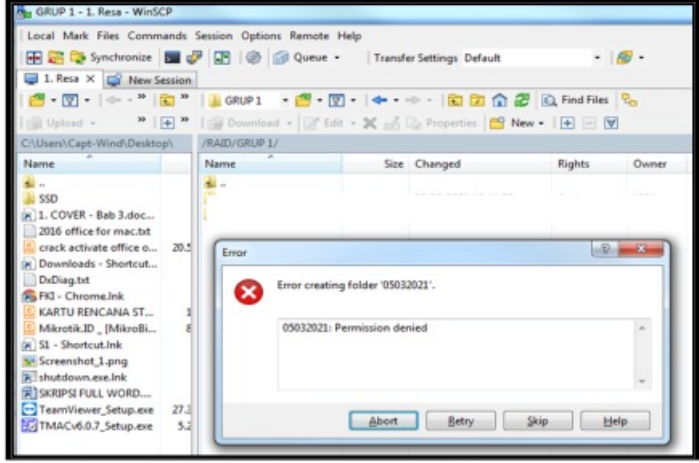

Gambar 4.94 Pembuatan gagal karena user Resa hanya bisa membaca

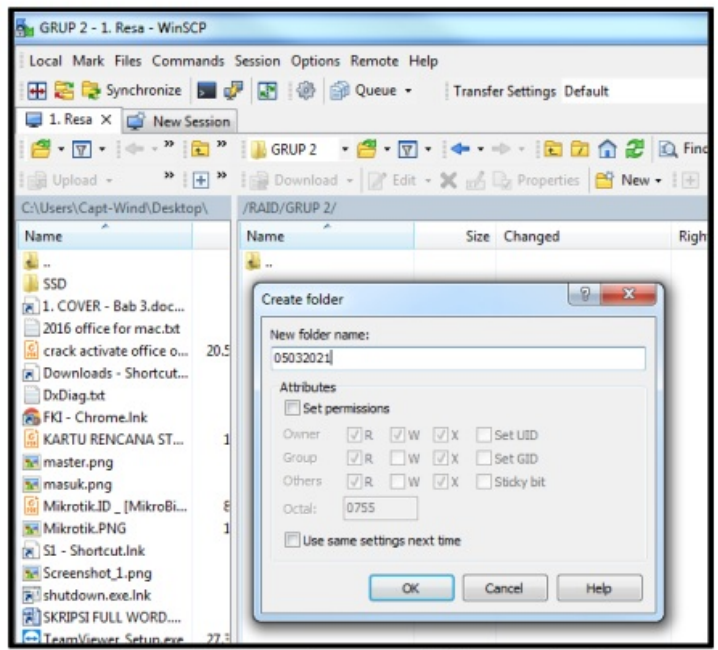

Gambar 4.95 Pembuatan folder pada Grup 2

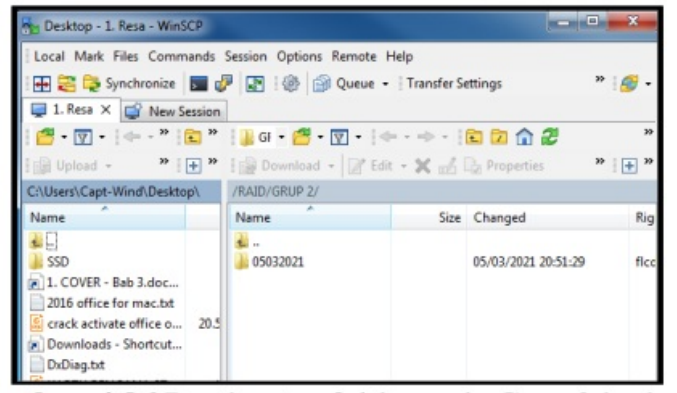

Gambar 4.96 Pembuatan folder pada Grup 2 berhasil 


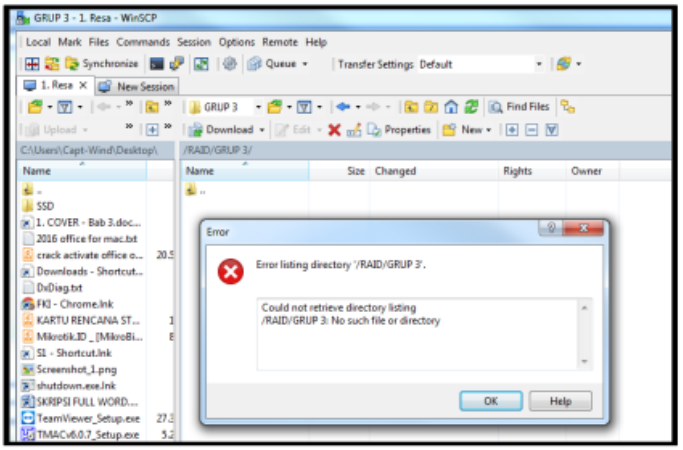

Gambar 4.97 Untuk di folder Grup 3, tidak berhasil diakses

Ujicoba selanjutnya, kita ujicoba di platform Ubuntu 20.10 tanpa mengunakan aplikasi pihak ketiga, langkah-langkahnya sebagai berikut;

3. Pertama masuk Explorer pada Operating Sistem Ubuntu 20.10, dibagain bawah masukan ftp://192.168.1.45:321, kenapa diberi “:321” hal itu menunjukan port, Kurang lebih penjelasnya seperti ini ;

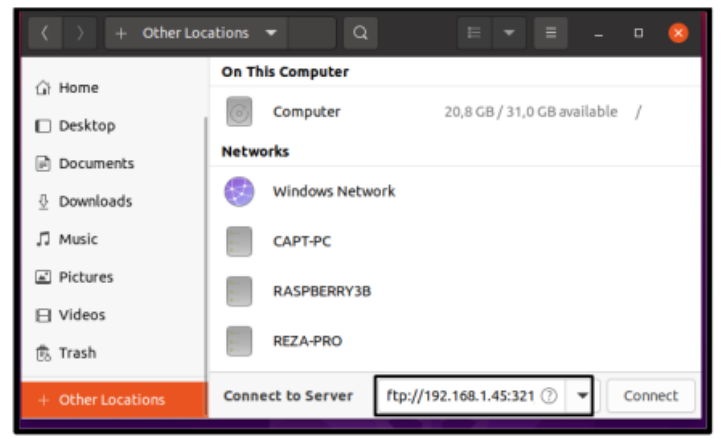

Gambar 4.98 Cara terhubung melalui FTP tanpa pihak ketiga

4. Untuk uji coba yang kedua, untuk login saya menggunakan user : aca dengan password : aca1234. Untuk user : aca, pada folder Group 1 user Aca bisa menulis dan membaca yang ada di direktori, difolder Group 2 tidak bisa diakses, Group 3 hanya bisa melihat isi dalam direktori, penjelasnya bisa dilihat seperti gambar dibawah ini ; 


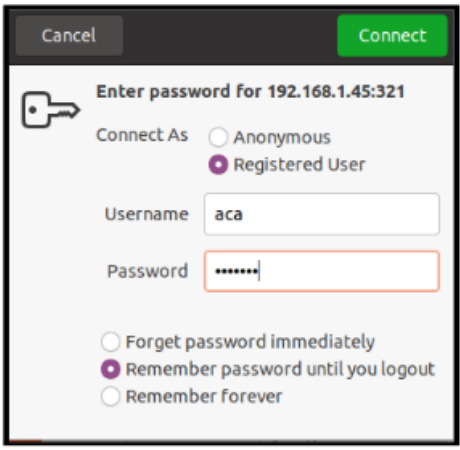

Gambar 4.99 Login menggunakan user Aca

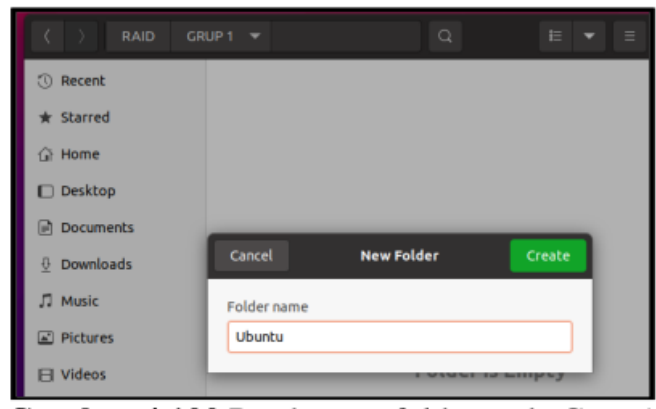

Gambar 4.100 Pembuatan folder pada Grup 1

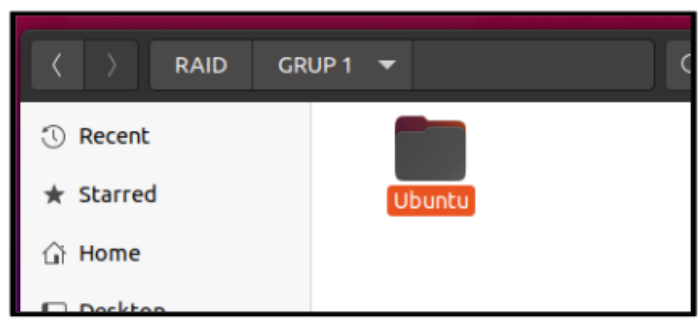

Gambar 4.101 Pembuatan folder pada Grup 1 berhasil

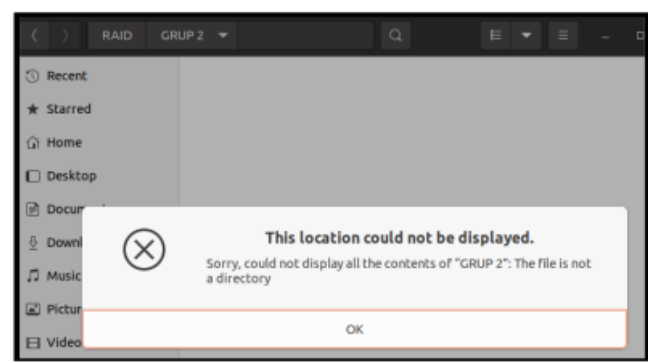

Gambar 4.102 Untuk di folder Grup 2, tidak berhasil diakses 


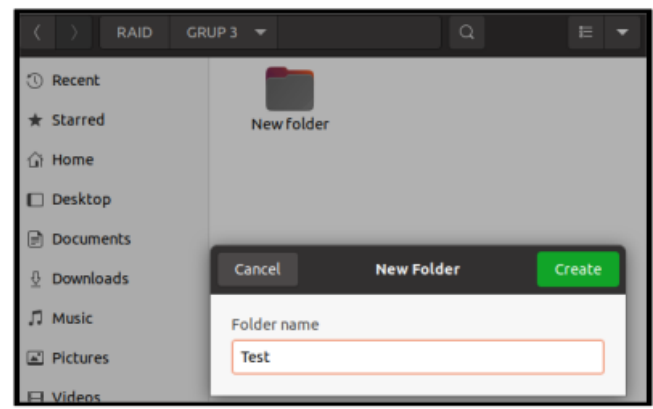

Gambar 4.103 Membuat folder pada folder grup 3

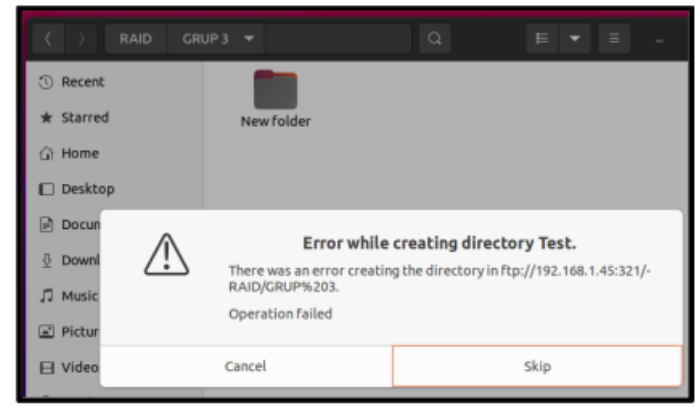

Gambar 4.104 Untuk di folder Grup 3, perintah tidak berhasil

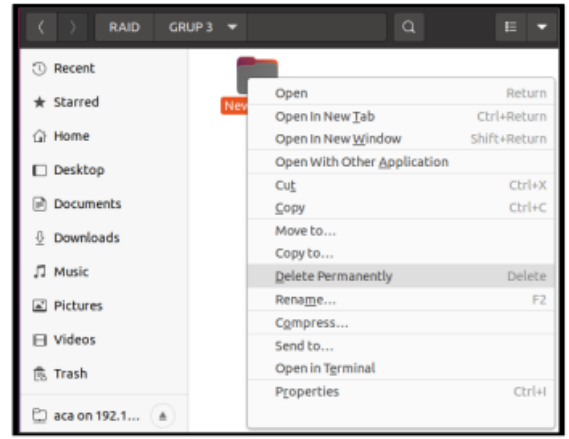

Gambar 4.105 Mencoba Menghapus folder dari folder Grup 3

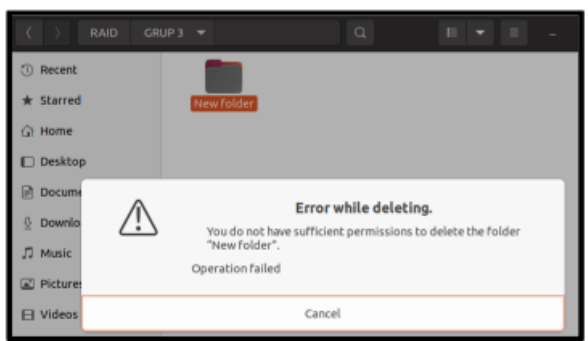

Gambar 4.106 Menghapus gagal dalam folder Grup 3 
Terakhir, ujicoba Protokol FTP selanjutnya, kita ujicoba di platform iPhone 5S dengan iOS 12.5.1 dengan mengunakan aplikasi pihak ketiga, yaitu FEFileExplorer, langkah-langkahnya sebagai berikut;

5. Download terlebih dahulu Apps "FEFileExplorer" di AppsStore.

Tampilanya seperti gambar berikut ini ;

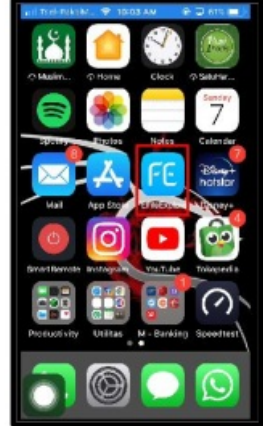

Gambar 4.107 Tampilan Aplikasi FEFileExplorer

6. Tampilan aplikasi "FEFileExplorer" pada Operating Sistem iOS 12.5.1, untuk menambahkan klik bagian pojok kanan atas tombol "+”, kurang lebih gambarnya seperti dibawah ini ;

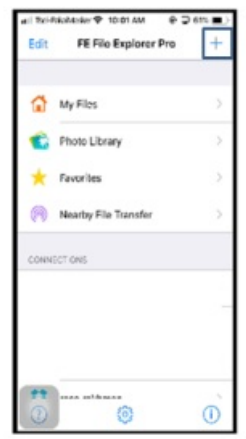

Gambar 4.108 Tampilan menu penambahan koneksi 
7. Selanjutnya pilih tambahan koneksi, pilih koneksi "FTP" untuk melanjutkan membuat koneksi pada Open Media Vault, seperti kurang lebih seperti gambar dibawah ini ;

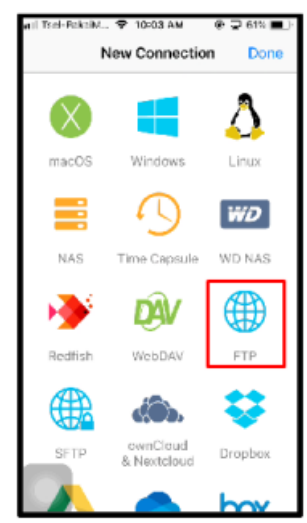

Gambar 4.109 Pilih tambahan berupa tambah koneksi

8. Isi form dibawah dengan mengisi Host dengan alamat IP = 192.168.1.45 masukan port dengan nomor 321, dan jangan lupa masukan user dengan nama ali dan password ali1234, kurang lebih penjelasnya seperti ini ;

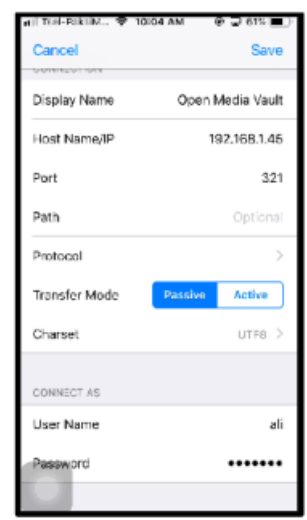

Gambar 4.110 Konfigurasi koneksi yang terhubung pada Open Media Vault 
9. Setelah tampilan sebelumnya selesai, maka tampak daftar list Open Media Vault

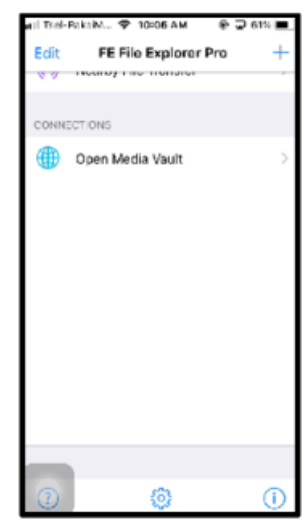

Gambar 4.111 Tampilan berhasil membuat koneksi dari tahapan sebelumnya

10.Untuk uji coba yang ketiga, login saya menggunakan user : ali dengan password : ali1234. Untuk user : ali, pada folder Group 1 user ali tidak bisa diakses, di folder Group 2 hanya bisa melihat isi dalam direktori, Group 3 bisa menulis dan membaca dalam direktori, penjelasnya bisa dilihat seperti gambar dibawah ini ;

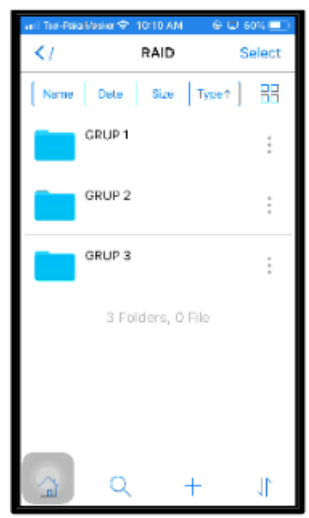

Gambar 4.112 Tampilan berhasil login dari user login Ali 


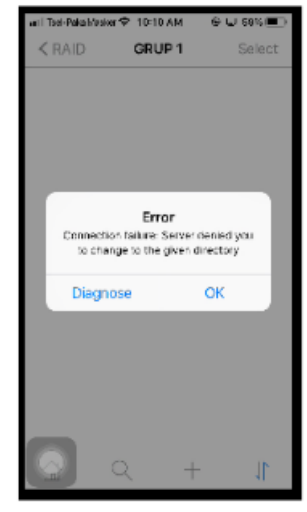

Gambar 4.113 Folder Grup 1 tidak berhasil diakses

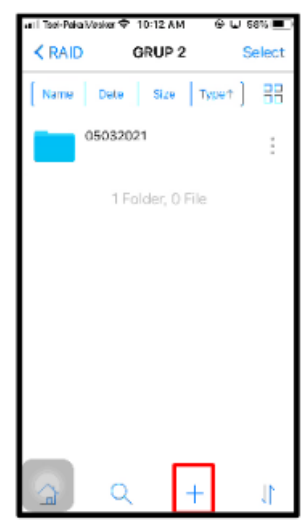

Gambar 4.114 Tahapan membuat folder pada Grup 2

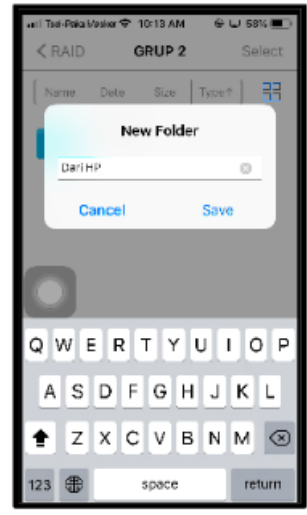

Gambar 4.115 Membuat nama pada folder Grup 2 


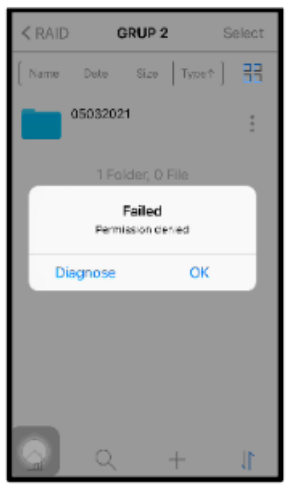

Gambar 4.116 Pada Grup 2 gagal membuat folder

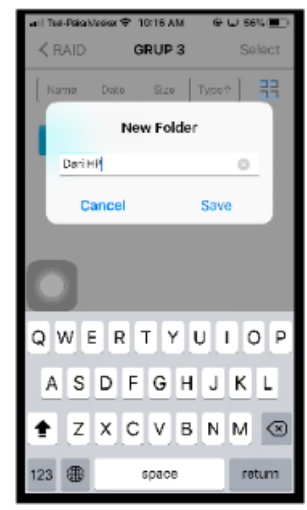

Gambar 4.117 Membuat nama pada folder Grup 3

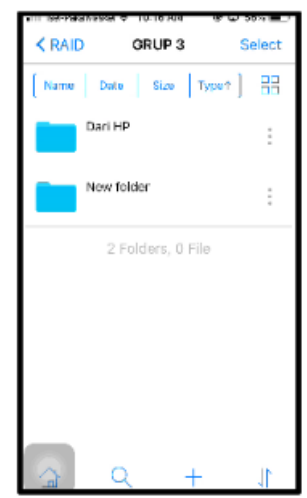

Gambar 4.118 Membuat folder berhasil pada folder Grup 3 


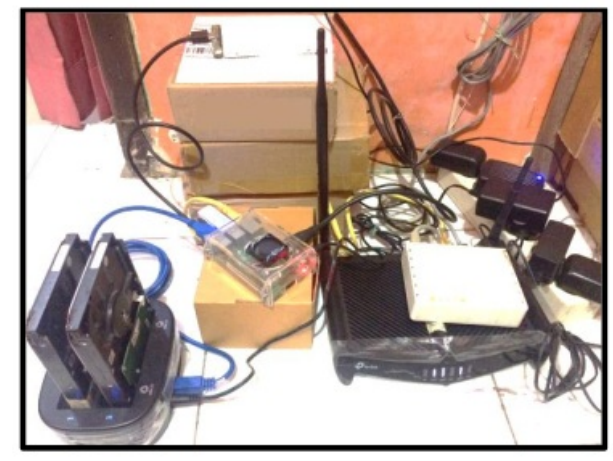

Gambar 4.119 Tampilan akhir rancang bangun dan implementasi penyimpanan file server berbasis IoT dengan Raspberry Pi $3 b+$ 


\section{BAB V \\ PENUTUP DAN KESIMPULAN}

\subsection{Kesimpulan}

Dari hasil Rancang Bangun dan Implementasi Penyimpanan file server berbasis IoT dengan Raspberry pi $3 b+$ menggunakan OMV, didapat kesimpulan sebagai berikut :

1. Rancang bangun dengan mengimplemetasikan penyimpanan file server berbasis Raspberry Pi 3b+ berjalan lama dan sedikit mengalami kendala namum berakhir dengan lancar

2. Mampu berjalan baik di lintas platform, baik di platform Windows, iPhone 5S dengan iOS 12.5.1 dan Linux khususnya Ubuntu versi 20.10.

3. Mempermudah pengguna dalam membutuhkan media penyimpanan dalam satu area network.

\subsection{Saran}

Adapun saran yang dapat disampaikan dalam rangka pengembangan sistem diatas antara lain;

1. Untuk pengembanggan dapat menggunakan Rancang bangun dengan Raspberry Pi 4 dengan berbagai macam variasi RAM dan kedepan diperlukanya dalam penambahan hardidisk maka dibutuhkan docking station usb 3.0 berisikan 2 slot atau lebih.

2. Diperlukan device tambahan berupa UPS (Uninterruptible power supply) pada power adapter Raspberry Pi 3b+ untuk 24 jam x 7 hari.

3. Dapat dilakukan dalam pengembangan dalam IP Publik.

4. Untuk lebih powerfull, alangkah lebih baik mendalami konsep untuk sistem RAID 0, RAID 1, RAID 3, RAID, 5 dan RAID 10 atau RAID 01 dan cara penanganan dalam bentuk recovery 


\section{DAFTAR PUSTAKA}

-, Kupas Tuntas Bermacam Aplikasi Generasi Cloud Computing, 2011. Semarang: Andi Publisher.

- , Virtual Server Administration Linux Virtual Server (LVS) for Red Hat Alamela, CA. 2000. Dictionary of Networking. USA: Sybex Inc.

Budi, Ronald, (2013). Administrasi Server dalam Jaringan Menggunakan Linux, Skripta, Malang.

Budi Sutedjo Dharma Oetomo, S. Kom. MM, (2008). Konsep dan Perancangan Jaringan Komputer, Yogyakarta : Penerbit Andi.

Doug, Lowe. 2005. Networking All-in-One Desk Reference for Dummies®, 2nd Edition. Wiley Publishing, Inc.: Canada.

Handaya, W.B.T, dkk, (2008). Linux System Administator Informatika, Bandung.

Kristanto, Andri. 2003, Jaringan Komputer. Yogyakarta: Graha Ilmu.

Niswar, Muh. 2011. Implementasi Virtual Document Pada Cloud Computing

Oetomo, Budi Sutedjo Dharma. 2006. Konsep \&Aplikasi Pemrograman Client Server \& Sistem Terdistribusi.Yogyakarta: Andi Offset.

Purbo, Onno W. 2000. Teknologi Warung Internet, Jakarta, Elexmedia Komputindo.

Rafiudin, Rahmad, (2004). Panduan menjadi Administator Sistem Linux, Andi, Yogyakarta.

Renaldy Suteja, Bernard. 2007. Linux System Administrator. Bandung: IF Informatika.

Sofana, Iwan. 2008, Membangun Jaringan Komputer. Bandung: IF Informatika Bandung.

Sugeng, Winarno. 2010. Jaringan Komputer dengan TCP/ IP. Bandung: Modula.

Pedoman Penyusunan Proposal dan Skripsi. 2010. Sidoarjo : Universitas Muhammadiyah Sidoarjo 


\section{Reza_rakhman_-_Skripsi.pdf}

ORIGINALITY REPORT

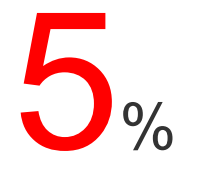

SIMILARITY INDEX
$5 \%$

INTERNET SOURCES
$0 \%$

PUBLICATIONS
$2 \%$

STUDENT PAPERS

PRIMARY SOURCES

1 repositori.uin-alauddin.ac.id

Internet Source

Exclude quotes Off

Exclude bibliography Off
Exclude matches

Off 